FABRÍCIO MENDES SOUZA

ESTUDO DA MICROESTRUTURA, DA TEXTURA CRISTALOGRÁFICA E DA RECRISTALIZAÇÃO EM CHAPAS OBTIDAS POR LINGOTAMENTO CONTÍNUO E SEMICONTÍNUO DA LIGA DE ALUMíNIO AA4006

São Paulo 
FABRÍCIO MENDES SOUZA

\section{ESTUDO DA MICROESTRUTURA, DA TEXTURA CRISTALOGRÁFICA E DA RECRISTALIZAÇÃO EM CHAPAS OBTIDAS POR LINGOTAMENTO CONTÍNUO E SEMICONTÍNUO DA LIGA DE ALUMÍNIO AA4006}

Tese apresentada à Escola Politécnica da Universidade de São Paulo para a obtenção do título de Doutor em Engenharia. 


\section{ESTUDO DA MICROESTRUTURA, DA TEXTURA CRISTALOGRÁFICA E DA RECRISTALIZAÇÃO EM CHAPAS OBTIDAS POR LINGOTAMENTO CONTÍNUO E SEMICONTÍNUO DA LIGA DE ALUMÍNIO AA4006}

Tese apresentada à Escola Politécnica da Universidade de São Paulo para a obtenção do título de Doutor em Engenharia.

Área de Concentração:

Engenharia Metalúrgica e de Materiais

Orientador:

Prof. Dr. Angelo Fernando Padilha 
Este exemplar foi revisado e alterado em relação à versão original, sob responsabilidade única do autor e com a anuência de seu orientador.

São Paulo, 22 de março de 2012.

Assinatura do autor

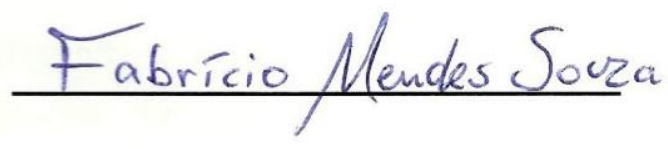

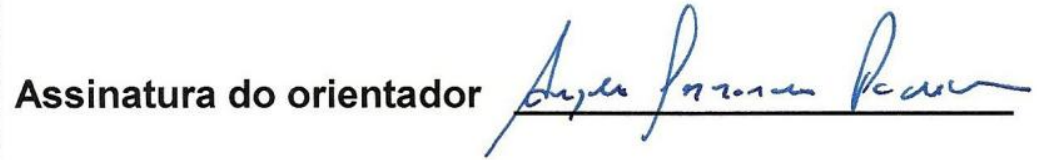

\section{FICHA CATALOGRÁFICA}

Souza, Fabrício Mendes

Estudo da microestrutura, da textura cristalográfica e da recristalização em chapas obtidas por lingotamento contínuo e semicontínuo da liga de alumínio AA4006 / F.M. Souza. -- ed.rev. -- São Paulo, 2012.

$107 \mathrm{p}$.

Tese (Doutorado) - Escola Politécnica da Universidade de São Paulo. Departamento de Engenharia Metalúrgica e de Materiais.

1. Materiais 2. Engenharia metalúrgica 3. Metalurgia física 4. Materiais metálicos 5 . Materiais não ferrosos 6 . Ligas metálicas I. Universidade de São Paulo. Escola Politécnica. Departamento de Engenharia Metalúrgica e de Materiais II. t. 


\section{AGRADECIMENTOS}

Ao prof. Dr. Angelo Fernando Padilha pelas importantes e valiosas sugestões durante a orientação do trabalho.

Ao prof. Dr Ronald Lesley Plaut pelas valiosas críticas construtivas e sugestões.

Ao Departamento de Engenharia Metalúrgica e de Materiais da Escola politécnica da Universidade de São Paulo (PMT-EPUSP) pela oportunidade do desenvolvimento deste trabalho.

Ao Conselho Nacional de Desenvolvimento Científico e Tecnológico (CNPq) pela bolsa de doutorado concedida (número de processo: 141783/2009-5).

Ao prof Dr. Nelson Batista de Lima (IPEN/CNEN-SP) pela realização das medidas de textura cristalográfica por meio da técnica de difração de raios $\mathrm{X}$, e, pelas relevantes discussões.

Ao engenheiro Dr. Ricardo do Carmo Fernandes (Companhia Brasileira de Alumínio CBA) por fornecer as amostras estudadas neste trabalho.

Aos técnicos Miguel Borodiak, Ivan Menegueço e Alex S. F. de Moraes (Companhia Brasileira de Alumínio CBA) por auxiliarem no polimento de amostras e obtenção das micrografias captadas por microscopia óptica com luz polarizada, bem como na obtenção das medidas de condutividade elétrica.

Aos engenheiros Francisco de Paula Pinheiro, Heber Pires Otomar e Marcelo Paes (Companhia Brasileira de Alumínio CBA) por dar as informações relacionadas às etapas e dados de produção das chapas da liga de alumínio AA4006.

Ao técnico Rafael Rocha Maia (Laboratório de Metalografia do PMT-EPUSP) por auxiliar no uso dos equipamentos. 
Ao técnico Rubens (Hall tecnológico PMT-EPUSP) por auxiliar no uso dos equipamentos.

Aos amigos Angelo José de Oliveira Zimmermann e Denilson José Marcolino de Aguiar (PMT-EPUSP) por sanarem algumas dúvidas relativas a este trabalho e pelos momentos de conversas e descontrações.

Aos amigos do programa de pós-graduação (PMT-EPUSP) Tiago, Leandro, Denise, Litzy, Maysa, Daniel, Girley, Eduardo, Denis, Felipe, Margarita, Lina, Mário pelos momentos de conversas e descontrações. 


\section{RESUMO}

A liga de alumínio designada AA4006 é muito utilizada na indústria. É uma liga do sistema Al-Fe-Si, com teores (\% em massa) de Si na faixa de 0,8 a 1,2\% e Fe entre 0,5 e $0,8 \%$. Apesar de ser bastante utilizada, ela foi pouco estudada. Neste trabalho foi realizado um estudo comparativo da microestrutura e da textura cristalográfica entre chapas da liga AA4006 produzidas por dois processos industriais de lingotamento: contínuo (Twin roll caster TRC) e semicontínuo (Direct chill DC). Para a caracterização microestrutural, foram utilizadas as técnicas de microscopia óptica com luz polarizada, microscopia eletrônica de varredura com microanálise química, medidas de condutividade elétrica e ensaios de dureza Brinell. A textura cristalográfica foi determinada por difração de raios $X$. Foram detectadas $e$ discutidas diferenças significativas nas morfologias e distribuições de grãos e de partículas de fases intermetálicas. O estudo da textura cristalográfica foi realizado ao longo da espessura das tiras e os resultados mostraram variações significativas da textura entre as chapas ao longo da espessura. A chapa produzida por lingotamento contínuo apresentou uma típica textura de cisalhamento nas proximidades de sua superfície, enquanto nas regiões mais internas a fibra $\beta$ foi observada. $O$ estudo da recristalização de chapas metálicas laminadas a frio é muito útil para a obtenção da temperatura de amolecimento do material submetido a um tratamento térmico. Tratamentos térmicos isócronos no intervalo de uma hora foram feitos em amostras das duas chapas e a chapa produzida pelo processo $T R C$ apresentou a temperatura para $50 \%$ de recristalização em torno de $290{ }^{\circ} \mathrm{C}$ e a amostra da chapa produzida pelo processo $D C$ em torno de $270 \stackrel{\circ}{ } \mathrm{C}$. A textura cristalográfica pode mudar com a recristalização e com a laminação do metal. Utilizando estas etapas de processamento do material, a orientação dos grãos de uma tira metálica pode ser otimizada, a fim de, por exemplo, melhorar a estampabilidade de chapas na obtenção de um dado produto com valor agregado. Neste trabalho as curvas de amolecimento para duas chapas produzidas por lingotamento contínuo e lingotamento semicontínuo da liga de alumínio AA4006 também foram determinadas e comparadas. Embora as diferenças detectadas entre as curvas de amolecimento tenham sido pequenas, foi possível verificar que a recristalização da chapa produzida por twin roll caster TRC ocorre em temperaturas mais elevadas do que na 
chapa produzida pelo processo direct chill $D C$. Resultados da textura cristalográfica em amostras destas chapas (laminadas e recozidas) foram obtidos utilizando difração de raios $X$ e difração de elétrons retroespalhados EBSD. Estes resultados indicaram a presença da textura de cisalhamento na superfície e a fibra $\beta$ no centro da amostra laminada a frio ( $70 \%$ de redução) da chapa obtida por lingotamento contínuo. Na amostra da chapa obtida por lingotamento semicontínuo, a componente cubo e a fibra $\beta$ foram vistas na superfície e no centro. Uma textura fraca com grãos orientados ao acaso foi vista nas duas amostras (TRC e $D C$ ) recristalizadas das duas chapas, possivelmente, devido à nucleação estimulada por partículas. $A$ fibra $\beta$ desapareceu nas amostras (TRC e $D C$ ) recristalizadas. 


\section{ABSTRACT}

AA4006 Aluminum alloy is extensively used in industry. It belongs to the Al-Fe-Si system, with Si between 0,8 and 1,2 \% mass, and Fe between 0,5 and 0,8 \% mass. This alloy is less studied despite its extensive use. A comparative microstructural study has been performed in as-received AA4006 alloy strip produced by two industrial casting processes: twin roll caster (TRC) and direct chill (DC). Polarized optical microscopy, scanning electron microscopy with microanalysis, electrical conductivity measurements and Brinnel hardness tests have been used for microstructural characterization. Significant differences in the grain and intermetallic particle sizes, morphologies and distributions were detected and are discussed. Thermal treatments effects on the silicon content in solid solution were also studied. Crystallographic textures have been also determined. Textures across thickness of both sheets have been analyzed and compared. Results showed significant texture changes across thickness of the specimens. Texture analysis was carried out using X-ray diffraction technique. Twin roll caster (TRC) sheet presented the typical shear texture near the surface, while, in internal regions, the $\beta$-fibre was observed. $A$ recrystallization study of cold rolled metallic sheets is very important to obtain softening temperature for the material during annealing. After cold rolling with $70 \%$ of reduction in thickness, followed by isochronous heat treatments, the samples of the two sheets produced by TRC and DC presented a 50\% recrystallization temperature around $290^{\circ} \mathrm{C}$ and $270^{\circ} \mathrm{C}$, respectively. Crystallographic texture can change during the metal rolling and recrystallization. These processing steps can optimize the grain orientation distribution in a metal strip to improve, for instance, the stamping process, in order to obtain an aggregated value product. Softening curves were also compared and determined for the two sheets (rolled and annealed) of the AA4006 aluminum alloy produced by twin roll caster TRC and direct chill DC processes. It was detected that the recrystallization of the strip produced by TRC process occurs at a higher temperature than that for the DC process, despite the little differences in their softening curves. Crystallographic texture results, for the sheet samples, were obtained by using X-ray diffraction and electron back scatter diffraction EBSD techniques. These results indicated the shear texture presence on the surface and $\beta$ fiber at the center of the cold rolled ( $70 \%$ area reduction) sample for the sheet 
produced by TRC process. In the sheet sample produced by the DC process, under the same conditions, the cube component and $\beta$ fiber texture (at the surface and at the center) were observed. A texture with random oriented grains was detected in two deformed and recrystallized samples of the two sheets (TRC and DC). It is suggested that this texture occurs due to the particle stimulated nucleation. There was $\beta$ fiber absence in the recrystallized samples (TRC and DC). 


\section{LISTA DE ILUSTRAÇÕES}

Figura 1.1 - Fluxograma das etapas envolvendo as atividades experimentais neste trabalho.

Figura 2.1 - Princípio esquemático da tecnologia de lingotamento semicontínuo (WOODWARD, 1994)

Figura 2.2 - Princípio esquemático da tecnologia de lingotamento contínuo (KAMMER, 1999)

Figura 2.3 - Diagrama ternário Al-Fe-Si no canto rico em Al com a quantidade de Fe fixa em 0,7\% em massa (GHOSH, 1992; MONDOLFO, 1976).....

Figura 2.4 - Relação entre a fração amolecida e a fração recristalizada para o alumínio (cujo símbolo na figura é o) e para o cobre (cujo símbolo na figura é •) (PADILHA; SICILIANO, 2005).

Figura 2.5 - (a) Curva tensão-deformação a quente com ocorrência somente de recuperação dinâmica. Mecanismos de restauração (recuperação e recristalização) possíveis durante a recuperação a quente (b) na laminação em baixas deformações para metais com alta EDE e baixa EDE e (c) na extrusão em altas deformações para metais com alta EDE e baixa EDE (PADILHA; SICILIANO, 2005).

Figura 2.6 - Goniômetro de textura com a geometria de reflexão (RANDLE; ENGLER, 2000)

Figura 3.1 - Desenho esquemático da realização da técnica de EBSD.

Figura 4.1 - Microestruturas obtidas por MO nas regiões (a) próxima à superfície e (b) central da chapa da liga AA4006 (no estado como recebido) obtida pelo processo $D C$. 
Figura 4.2 - Microestruturas obtidas por MO nas regiões (a) próxima à superfície e (b) central da chapa da liga AA4006 (no estado como recebido) obtida pelo processo TRC

Figura 4.3 - Micrografias obtidas por MEV mostrando a distribuição dos precipitados nas regiões (a) próxima à superfície e (b) central da chapa da liga AA4006 (no estado como recebido) obtida pelo processo $D C$

Figura 4.4 - Micrografias obtidas por MEV mostrando a distribuição dos precipitados nas regiões (a) próxima à superfície e (b) central da chapa da liga AA4006 (no estado como recebido) obtida pelo processo TRC

Figura 4.5 - Micrografias obtidas por MEV mostrando a distribuição mais ampla dos precipitados na região central das chapas da liga AA4006 (no estado como recebido) obtidas pelos processos (a) $D C$ (b) TRC.

Figura 4.6 - (a) Microestrutura obtida por MO da espessura (amostra anodizada com solução contendo $\mathrm{HBF}_{4}$ ) e (b) micrografia com maior aumento obtida por MO (ataque químico em solução contendo HF) mostrando a distribuição lamelar dos precipitados na região central da chapa da liga AA4006 (no estado como recebido) obtida pelo processo TRC

Figura 4.7 - Relação entre o tamanho da célula dendrítica e a taxa de solidificação para ligas de alumínio (SPEAR; GARDNER, 1963).

Figura 4.8 - (a) Diagrama binário de equilíbrio Al-Si (JACOBS, 1999), (b) superfície liquidus do diagrama ternário Al-Fe-Si no canto rico em Al (ALLEN et al, 1998) e (c) diagrama ternário Al-Fe-Si no canto rico em Al com a quantidade de Fe fixa em 0,7 \% em massa (GHOSH, 1992; MONDOLFO, 1976). 
Figura 4.9 - Precipitados encontrados em amostras da região central da chapa da liga AA4006 (no estado como recebido) obtida pelo processo $D C$, (a) seção normal e (c) seção transversal. (b) e (d) Espectros de dispersão de energia (EDS) destes precipitados indicados pelas setas nas micrografias

Figura 4.10 - Aglomerados de precipitados (a) na seção transversal encontrados em amostras da região central da chapa da liga AA4006 (no estado como recebido) obtida pelo processo $T R C$ e (c) na seção normal. (b) e (d) Espectros de dispersão de energia (EDS) destes precipitados indicados pelas setas nas micrografias

Figura 4.11 - Seções da FDO mostrando a localização das orientações $\{011\}<100>$ (cujo símbolo na figura é ${ }^{\text {) }}$ e $\{011\}<112>$ (cujo símbolo na figura é -) comumente encontradas em metais com estrutura cúbica. Para melhores detalhes ver referência (ALUMATTER, 2010)

Figura 4.12 - Figuras de pólo (111) e FDO's para a superfície, 1/4 e centro da chapa produzida pelo processo TRC da liga AA4006

Figura 4.13 - Figuras de pólo (111) e FDO's para a superfície, 1/4 e centro da chapa produzida pelo processo $D C$ da liga AA4006

Figura 4.14 - Micrografias obtidas por ataque profundo nas amostras das duas chapas (a) e (c) e micrografias dos precipitados extraídos destas amostras (b) e (d) 56

Figura 4.15 - Aglomerados de precipitados encontrados em amostras da chapa da liga AA4006 (no estado como recebido) obtida pelo processo TRC com seus respectivos espectros de dispersão de energia (EDS) destes 
precipitados indicados pelas setas nas micrografias.

Figura 4.16 - Precipitados encontrados em amostras da chapa da liga AA4006 (no estado como recebido) obtida pelo processo $D C$ com seus respectivos espectros de dispersão de energia (EDS) destes precipitados indicados pelas setas nas micrografias

Figura 4.17 - Curvas da variação da microdureza (HV) das amostras obtidas das chapas produzidas pelos processos $D C$ e TRC da liga AA4006 laminadas a frio com $70 \%$ de redução em área, em função da temperatura e micrografias das distribuições dos precipitados antes e após a recristalização.

Figura 4.18 - Diagrama esquemático de tempo, temperatura e transformação (TTT) (KOSTER, 1974) (a) e diagramas TTT de uma liga (Al-Mn-Fe-Si) que foi inicialmente submetida ao tratamento térmico de solubilização (supersaturada), em seguida foi deformada a frio e finalmente recozida (TANGEN et al, 2010) (b).

Figura 4.19 - Curvas da variação da microdureza (HV) de alumínios recozidos após laminação a frio com $70 \%$ de redução em área (OLIVEIRA, 2009) e das ligas AA4006 TRC e DC, em função das temperaturas do tratamento térmico.

Figura 4.20 - Curvas (derivadas) das taxas de variação da microdureza em função da temperatura $(\mathrm{dHV} / \mathrm{dT})$ para as amostras obtidas das chapas produzidas pelos processos $D C$ e TRC da liga AA4006 laminadas a frio com $70 \%$ de redução em área.

Figura 4.21 - Figuras de pólo (111), (200), (220) e (311) (a) e FDO's na superfície da amostra laminada com redução de $70 \%$ em área da chapa produzida pelo processo $T R C$ da liga AA4006 (b). 
Figura 4.22 - Figuras de pólo (111), (200), (220) e (311) (a) e FDO no centro da amostra laminada com redução de $70 \%$ em área da chapa produzida pelo processo TRC da liga AA4006 (b).....

Figura 4.23 - Figuras de pólo (111), (200), (220) e (311) (a) e FDO na superfície da amostra laminada com redução de $70 \%$ em área da chapa produzida pelo processo $D C$ da liga AA4006 (b).

Figura 4.24 - Figuras de pólo (111), (200), (220) e (311) (a) e FDO no centro da amostra laminada com redução de $70 \%$ em área da chapa produzida pelo processo $D C$ da liga AA4006 (b).

Figura 4.25 - Fibra $\{100\}$ na superfície (a) e no centro (b) da amostra laminada com redução de $70 \%$ em área da chapa produzida pelo processo $D C$ da liga AA4006.

Figura 4.26 - Evolução da textura em amostras das chapas $D C$ analisadas (a) na região superficial (no estado como recebido e laminado a frio com $70 \%$ de redução em área), (b) na região central (no estado como recebido e laminado a frio com $70 \%$ de redução em área) e (c) recristalizada.

Figura 4.27 - Evolução da textura das amostras das chapas TRC analisadas (a) na região superficial (no estado como recebido e laminado a frio com $70 \%$ de redução em área), (b) na região central (no estado como recebido e laminado a frio com $70 \%$ de redução em área) e (c) recristalizada.

Figura 4.28 - Figuras de pólo (111), (200), (220) e (311) (a) e FDO da amostra laminada (com redução de $70 \%$ em área) e recozida da chapa produzida pelo processo TRC da liga AA4006 (b). 
Figura 4.29 - Figuras de pólo (111), (200), (220) e (311) (a) e FDO da amostra laminada (com redução de $70 \%$ em área) e recozida da chapa produzida pelo

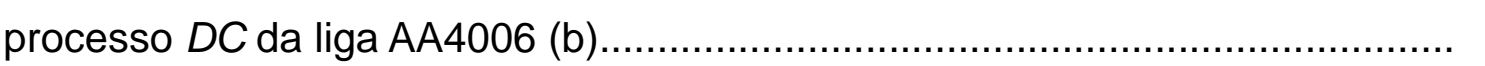

Figura 4.30 - Imagem das orientações cristalográficas dos grãos da microestrutura da amostra laminada (com redução de $70 \%$ em área) e recozida da chapa produzida pelo processo $T R C$ da liga AA4006

Figura 4.31 - Imagem das orientações cristalográficas dos grãos da microestrutura da amostra laminada (com redução de $70 \%$ em área) e recozida da chapa produzida pelo processo $D C$ da liga AA4006

Figura 4.32 - Figuras de pólo (111), (200), (220) e (311) da amostra laminada com redução de $70 \%$ em área e recozida da chapa produzida pelo processo $T R C$ da liga AA4006.

Figura 4.33 - Figuras de pólo (111), (200), (220) e (311) da amostra laminada com redução de $70 \%$ em área e recozida da chapa produzida pelo processo $D C$ da liga AA4006

Figura 4.34 - FDO's da amostra laminada com redução de 70\% em área e recozida da chapa produzida pelo processo $T R C$ da liga AA4006

Figura 4.35 - FDO's da amostra laminada com redução de 70\% em área e recozida da chapa produzida pelo processo $D C$ da liga $A A 4006$

Figura 4.36 - Distribuição das frações de contornos de grão na área mapeada por $E B S D$ em função do ângulo de orientação para a amostra (TRC) laminada com redução de $70 \%$ em área e recozida. 
Figura 4.37 - Distribuição das frações de contornos de grão na área mapeada por $E B S D$ em função do ângulo de orientação para a amostra $(D C)$ laminada com redução de 70\% em área e recozida........................................................

Figura 4.38 - Mapeamento do fator de Taylor (a) e do índice de qualidade (b) da amostra laminada com redução de $70 \%$ em área e recozida da chapa produzida pelo processo $T R C$

Figura 4.39 - Mapeamento do fator de Taylor (a) e do índice de qualidade (b) da amostra laminada com redução de $70 \%$ em área e recozida da chapa produzida pelo processo $D C$

Figura 4.40 - Distribuição das frações de contornos de grão na área mapeada por $E B S D$ em função do ângulo de orientação juntamente com os respectivos ajustes (linhas de tendência) para as amostras (TRC e $D C$ ) laminadas com redução de $70 \%$ em área e recozidas (a) e freqüência da relação de orientação para a distribuição ao acaso (Distribuição de Mackenzie) (b) (MACKENZIE, 1958).

Figura 4.41 - Desenho esquemático das deformações no embutimento profundo e no estiramento no diagrama limite de conformação (a) e Curva Limite de Conformação de uma chapa da liga de alumínio AA3003 não tratável termicamente (b) (KOHARA 1993) 


\section{LISTA DE TABELAS}

Tabela 4.1 - Composições químicas (\% em massa) ao longo da espessura (8 $\mathrm{mm}$ ) de amostras das chapas obtidas pelos processos $D C$ e $T R C$ da liga AA4006.

Tabela 4.2 - Fases sólidas, suas faixas de temperatura e parâmetros de rede (GHOSH, 1992)......

Tabela 4.3 - Condutividades elétricas de amostras das chapas obtidas pelos processos $D C$ e TRC da liga AA4006 em diferentes temperaturas e tempos.

Tabela 4.4 - Medidas de dureza Brinnell de amostras das chapas obtidas pelos processos $D C$ e $T R C$ da liga AA4006 em diferentes temperaturas e tempos.

Tabela 4.5 - Diâmetro médio dos grãos de amostras das chapas obtidas pelos processos DC e TRC da liga AA4006 no estado "como recebido".

Tabela 4.6 - Componentes de textura ao longo da espessura de chapas produzidas pelo processo $D C$ (laminadas a quente) das ligas AA1100, AA1050, AA1070 (OLIVEIRA; PADILHA, 2009) e AA3003 (MARTINS, 2005)..

Tabela 4.7 - Medidas de microdureza Vickers das amostras das chapas obtidas pelos processos $D C$ e $T R C$ da liga AA4006 tratadas em diferentes temperaturas durante uma hora.

Tabela 4.8 - Condutividades elétricas de amostras das chapas obtidas pelos processos $D C$ e TRC da liga AA4006 em tratadas em diferentes temperaturas durante uma hora. 


\section{LISTA DE SIGLAS E SÍMBOLOS}

\begin{tabular}{|c|c|}
\hline $\mathrm{Al}$ & Alumínio \\
\hline at & atômico \\
\hline CFC & Cúbica de face centrada \\
\hline $\mathrm{Cr}$ & Cromo \\
\hline $\mathrm{Cu}$ & Cobre \\
\hline $\mathrm{DC}$ & Direct chill \\
\hline DL & Direção de laminação \\
\hline DN & Direção normal \\
\hline DT & Direção transversal \\
\hline EBSD & Electron back-scatter diffraction \\
\hline EDE & Energia de defeito de empilhamento \\
\hline FDO & Função de distribuição de orientação \\
\hline $\mathrm{Fe}$ & Ferro \\
\hline F.P. & Figura de pólo \\
\hline $\mathrm{HB}$ & Hardness brinnel \\
\hline HV & Hardness vickers \\
\hline IACS & International annealed copper standard \\
\hline IQ & Índice de qualidade \\
\hline MEV & Microscopia eletrônica de varredura \\
\hline $\mathrm{Mg}$ & Magnésio \\
\hline $\mathrm{Mn}$ & Manganês \\
\hline $\mathrm{MO}$ & Microscopia óptica \\
\hline $\mathrm{Ni}$ & Níquel \\
\hline r & Raio médio das partículas \\
\hline SEM & Scanning electron microscope \\
\hline
\end{tabular}


Si Silício

T Temperatura

$\mathrm{T}_{1} \quad$ Temperatura no instante 1

$\mathrm{T}_{2} \quad$ Temperatura no instante 2

TEM Transmission electron microscope

TRC Twin roll caster

Ti Titânio

$T_{R} \quad$ Temperatura de início da recristalização

TP Temperatura de início da precipitação

TTT Temperatura, tempo e transformação

V Vanádio

Zn Zinco

Y Energia superficial do contorno de grão

$\Delta \mathrm{E} \quad$ Diferença de energia armazenada

$\triangle \mathrm{P} \quad$ Somatória de potenciais termodinâmicos e forças retardadoras que atuam sobre o contorno 


\section{SUMÁRIO}

1 INTRODUÇÃO. 1

2 REVISÃO BIBLIOGRÁFICA

2.1 $O$ alumínio e suas ligas 5

2.20 processo de solidificação e o sistema Al-Fe-Sí............................... 11

2.3 Fatores que afetam a estrutura dos metais deformados.

2.4 Evolução microestrutural durante a deformação e suas heterogeneidades................................................................................... 15

2.5 O Tratamento térmico de homogeneização e a laminação a quente...... 16

2.6 Recuperação e recristalização de ligas metálicas................................ 20

2.7 Importância da textura cristalográfica nos metais................................ 22

3 MATERIAIS E MÉTODOS

3.1 Material......................................................................................... 26

3.1.1 Composição química.......................................................................... 26

3.1.2 Processamento das chapas da liga de alumínio AA4006................... 26

3.2 Métodos.............................................................................................. 26

3.2.1 Recozimento inicial........................................................................ 27

3.2.2 Laminação a frio.................................................................................... 27

3.2.3 Tratamento térmico das amostras laminadas.................................... 28

3.3 Técnicas de análise microestrutural............................................... 28

3.3.1 Preparação metalográfica............................................................. 28

3.3.2 Microscopia óptica (MO)............................................................. 29

3.3.3 Microscopia óptica com luz polarizada........................................... 29

3.3.4 Microscopia eletrônica de varredura (MEV).................................... 30

3.3.5 Difração de raios X (DRX) ............................................................... 30

3.3.6 Condutividade elétrica................................................................. 31

3.3.7 Microdureza Vickers (HV) e dureza Brinell..................................... 31

3.3.8 Difração de elétrons retroespalhados EBSD.................................. 32 
4.1 Microestruturas das amostras das chapas obtidas pelos processos $D C$ e $T R C$ no estado como recebido.

4.1.1 Composição química......................................................................... 34

4.1.2 Microestruturas das chapas............................................................ 35

4.1.3 Condutividade elétrica, dureza e tamanho de grão............................. 49

4.2 Texturas cristalográficas das chapas no estado como

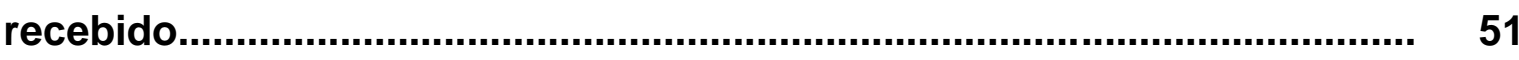

4.2.1 Textura nas amostras das chapas obtidas pelos processos $D C \mathrm{e}$ TRC.

4.3 Extração dos precipitados nas amostras das duas chapas no estado como recebido.

4.4 Recristalização e microdureza nas amostras das duas chapas laminadas a frio e recozidas

4.5 Texturas cristalográficas (obtidas por difração de raios $X$ ) em amostras das chapas laminadas a frio e recristalizadas.

4.6 Obtenção das texturas cristalográficas por meio da técnica de difração de elétrons retroespalhados EBSD em amostras recristalizadas das chapas laminadas.

4.7 Considerações finais.

5 CONCLUSÕES.

5.1 Microestrutura e textura cristalográfica das chapas no estado como recebido.

5.2 Recristalização e textura cristalográfica das chapas laminadas e seguidas de recristalização. 


\section{INTRODUÇÃO}

O alumínio é um metal leve, dúctil, resistente à corrosão, não tóxico, bom condutor de calor, ótimo condutor de eletricidade e pode ser processado para ter bons limites de escoamento e de resistência. Essas vantagens conferem apreciável versatilidade às diversas aplicações do alumínio e suas ligas, nos dias atuais, conduzindo-se ao elevado consumo desses materiais (ABAL, 2004; ABAL, 2006). O alumínio e suas ligas podem ser produzidos, utilizando-se os processos de fabricação de chapas bobinadas diretamente do metal fundido (Twin roll caster $T R C$ ), e, pelo tradicional método de vazamento de placas seguido de posterior laminação a quente (Direct chill $D C$ ). Para facilitar a leitura, a partir daqui, os nomes (em inglês) desses processos serão escritos, utilizando-se suas respectivas letras iniciais $T R C$ e $D C$. No processo $T R C$, há uma considerável economia de custos na produção das ligas de alumínio, já que não são necessárias as etapas de fresamento (remoção superficial da camada de óxido, de impurezas e da segregação inversa) e de laminação a quente como ocorre no processo $D C$, além disso, no processo TRC, há a facilidade de alteração da espessura e da largura de vazamento, sem necessidade de alterar as dimensões do molde (FERNANDES, 2008; MINATEL, 2009; OTOMAR, 2010).

A chapa de alumínio, produzida pelo processo TRC, apresenta uma microestrutura (dendrítica) bastante diferenciada da microestrutura da chapa laminada a quente, no processo DC (MINATEL, 2009), pois há uma maior taxa de resfriamento envolvida durante o processamento da chapa produzida pelo processo $T R C$ do que na chapa produzida pelo processo $D C$. Dessa forma, no processo TRC, precipitados mais finos podem se formar na superfície, e o posterior tratamento térmico pode causar a precipitação de elementos de liga que ficaram retidos em solução sólida supersaturada (MARTINS; CARVALHO; PADILHA, 2009; SOUZA et al, 2011). Por isto, o tratamento térmico de homogeneização pode ser utilizado, a fim de alterar a distribuição dos precipitados. Vale lembrar que o tamanho dos grãos pode variar com o aumento da taxa de resfriamento na solidificação (SPEAR; GARDNER, 1963).

Distintos produtos do alumínio e de suas ligas podem ser obtidos, utilizandose o processamento desses materiais. Dentre os diversos processos de produção, 
de transformação mecânica e de transformação estrutural, se encontra o processo chamado de estampagem, usado para modelar chapas planas em produtos mais trabalhados e com maior valor agregado (PLAUT, 2003). Para a preparação e otimização dessas chapas, na obtenção do produto final, torna-se relevante estudar a evolução e o desenvolvimento da microestrutura e da textura cristalográfica durante as etapas de transformação térmica e mecânica das chapas metálicas (ENGLER; HIRSCH, 2007; LIU; ZHAI; MORRIS, 2004). A investigação de orientações preferenciais dos grãos (macrotextura) de uma liga metálica pode ser feita, utilizando-se a técnica de difração de raios X (ENGLER; LÜCKE, 1992; ENGLER; HIRSCH, 2002). As ligas de alumínio produzidas industrialmente apresentam textura cristalográfica, a qual pode ser analisada a partir do método de reflexão com o uso dessa técnica.

As chapas de alumínio das ligas não tratáveis termicamente (endurecíveis por trabalho mecânico) são utilizadas para a produção de componentes na indústria automobilística, assim como na produção de utensílios domésticos e de latas de bebidas (ENGLER; HIRSCH, 2002). A liga AA4006 do sistema Al-Fe-Si apresenta boa conformabilidade e é usada na fabricação de utensílios de cozinha (HOFFMANN; CORTES, 2003). Dessa forma, a viabilidade do uso desses materiais depende do conhecimento de suas características microestruturais e dos parâmetros envolvidos nos processos de laminação, conformação mecânica, tratamento térmico, dentre outros.

Durante o tratamento térmico de ligas metálicas há a ocorrência dos fenômenos conhecidos como recuperação e recristalização. Na recuperação surgem mudanças na subestrutura do material deformado, como a diminuição da quantidade de defeitos puntiformes, a aniquilação de discordâncias, o encolhimento de anéis de discordâncias, o rearranjo de discordâncias para configurações de menor energia e a formação de contornos de grão de alto ângulo. Já na recristalização, ocorrem na microestrutura, a absorção de defeitos puntiformes e de discordâncias, devido à movimentação de contornos de alto ângulo e o aumento da área total dos contornos de grãos no refinamento de grão (PADILHA; SICILIANO, 2005). Estas mudanças que surgem no material durante seu tratamento térmico contribuem para o amolecimento da liga metálica (SOUZA et al, 2011).

As impurezas ou elementos de liga Fe e Si são comumente encontrados no alumínio comercialmente puro, devido a isto, a região da borda do Al (próxima de 
100\% de Al), no diagrama ternário do sistema Al-Fe-Si, já foi, extensivamente, estudada. Vários autores encontraram em seus estudos diferentes fases binárias e ternárias envolvendo estes três componentes (ALLEN et al, 1998; GHOSH, 1992; MONDOLFO, 1976; GOULART, 2010). Os elementos contidos nestas fases podem se dissolver ou precipitarem na matriz durante tratamentos térmicos (OLIVEIRA, 2009; FALLEIROS 1972; FERNANDES; PADILHA, 2008).

A textura cristalográfica de chapas de ligas de alumínio tem sido muito estudada, e uma textura de cisalhamento próxima à superfície da tira, bem como uma textura de laminação na região central foram detectadas (BENUM; ENGLER; NES, 1994; GRAS; MEREDITH; HUNT, 2005). As componentes de textura podem variar tanto ao longo da espessura da chapa quanto em cada processo de produção (MARTINS, 2005; FERNANDES, 2006), bem como podem mudar quando a liga é recozida (LIU; MORRIS, 2002; ENGLER; KIM; HUH, 2001; ENGLER, 1996). A análise da orientação cristalográfica de pequenas quantidades de grãos e dos contornos entre estes grãos (microtextura e mesotextura) pode ser feita utilizando a técnica de difração de elétrons retroespalhados (electron backscatter diffraction), denominada EBSD neste texto (PADILHA, 1999; PINTO; LOPES, 2001).

Uma liga contendo partículas pode apresentar nucleação da recristalização no entorno das mesmas, levando-se ao aparecimento de uma fraca textura na liga (ENGLER, 1997; DOHERTY, 1997). A liga de alumínio AA4006 é uma liga pouco estudada. Portanto torna-se relevante avaliar sua textura cristalográfica, suas principais componentes e a microestrutura da liga relacionando-as com os fenômenos de encruamento, recuperação, recristalização e crescimento de grão, envolvidos nos processos de tratamentos térmicos e mecânicos e, por fim, comparálos com outras ligas de alumínio (não tratáveis termicamente) já estudadas. Vale lembrar que diferentes elementos de liga com variados teores são usados na composição das ligas de alumínio de outras séries, como o Mn, o $\mathrm{Mg}$ e outros, os quais podem mudar as propriedades microestruturais desses materiais.

Os principais objetivos desse trabalho são: a caracterização da microestrutura e da textura cristalográfica ao longo da espessura de chapas (duas amostras da liga AA4006) no estado como recebido pertencentes ao sistema Al-Fe-Si e produzidas por lingotamento contínuo (Twin roll caster) e lingotamento semicontínuo (Direct chill). Analisar a condutividade elétrica (após tratamentos térmicos), a dureza e levantar curvas de amolecimento e recristalização (após tratamentos térmicos e 
mecânicos) dessas amostras. Estudar e compreender melhor os fenômenos de encruamento, recuperação, recristalização e crescimento de grão, envolvidos nas etapas evolutivas do processamento térmico e mecânico das amostras das chapas (no estado como recebido, laminadas e seguidas de recristalização) obtidas pelos dois processos industriais.

Abaixo está o fluxograma com as etapas do estudo feito (neste trabalho) nas tiras metálicas das ligas AA4006 produzidas por TRC e DC (Figura 1.1):

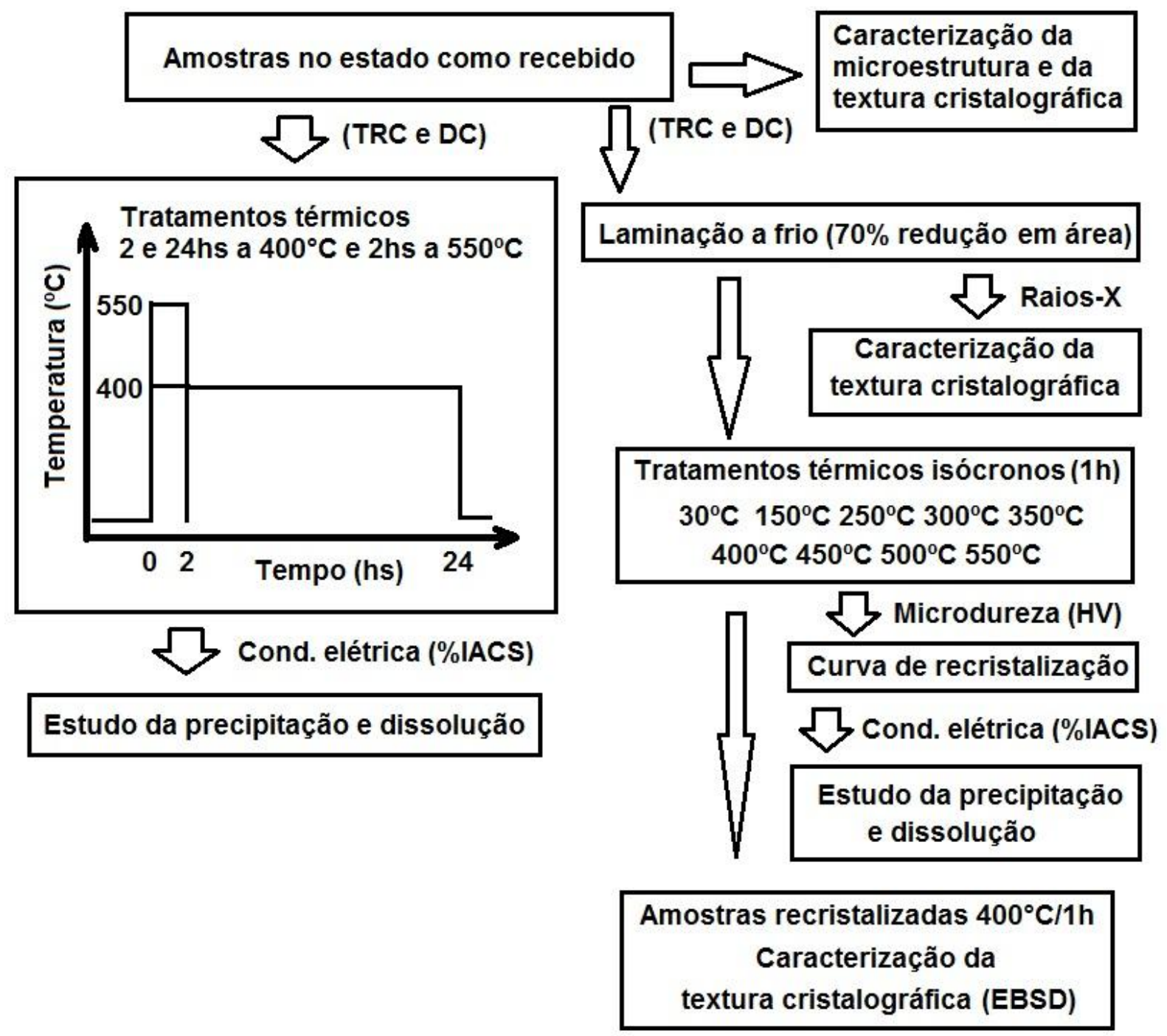

Figura 1.1 - Fluxograma das etapas envolvendo as atividades experimentais neste trabalho. 


\section{REVISÃO BIBLIOGRÁFICA}

Neste capítulo será feito um estudo, baseado na literatura, sobre a obtenção e a importância das diversas aplicações do alumínio e suas ligas, bem como uma análise sucinta do sistema ternário Al-Fe-Si no canto rico em alumínio. Serão também abordados os processos de solidificação e produção ( $D C$ e $T R C$ ) de metais, o tratamento térmico de homogeneização, bem como os seguintes temas; a laminação a quente, o estado deformado, a evolução microestrutural, as heterogeneidades durante a deformação, os fatores que afetam a microestrutura dos metais deformados, assim como os fenômenos de encruamento e recristalização e a relação que estes fenômenos têm com a textura cristalográfica.

\subsection{O alumínio e suas ligas}

A produção de alumínio no Brasil se iniciou por volta de 1940 com a importante realização de projetos implantados por brasileiros e estrangeiros, surgindo a partir daí, um interessante segmento para a economia brasileira, já que no país já estava sendo estudada a exploração dos principais insumos para a produção de alumínio, devido às grandes reservas de bauxita e potencial hidrelétrico. O nome bauxita originou-se de Les Baux (localizada no sul da França) e começou a ser mencionado em 1808. Próximo do final do século XIX, os processos Bayer (produção de alumina $\mathrm{Al}_{2} \mathrm{O}_{3}$ ) e o Hall-Heroult (metalurgia do alumínio) permitiram o desenvolvimento do uso do alumínio em escala industrial, pois, até então, o metal foi apenas isolado ou produzido com alto custo. A energia elétrica, advinda da energia hidráulica, sempre teve uma participação importante na indústria do alumínio no Brasil (MACHADO, 1985; ABAL, 2004).

Basicamente, o método de produção do alumínio está baseado no processo que envolve a mineração da bauxita e seu posterior tratamento químico para produzir a alumina $\left(\mathrm{Al}_{2} \mathrm{O}_{3}\right)$, a partir daí há a redução do $\mathrm{Al}_{2} \mathrm{O}_{3}$ em $\mathrm{Al}$ utilizando a redução eletrolítica. Nos anos decorrentes do último século, este processo tem sido constantemente melhorado, a fim de obter maior eficiência e diminuição de gastos na produção do alumínio (BUDD, 1999). No processo de redução da alumina 
$\left(\mathrm{Al}_{2} \mathrm{O}_{3}\right.$ ), o alumínio metálico é comumente obtido com $99,7 \%$ de pureza (DAVIS, 1993).

A produção de chapas de alumínio e suas ligas pode ser feita, utilizando-se a técnica de lingotamento semicontínuo (Direct chil) e a técnica de lingotamento contínuo (Twin roll caster). No processo de lingotamento semicontínuo, placas com mais de 20 toneladas são produzidas, com dimensões em torno de $500-600 \mathrm{~mm}$ de espessura, $2000 \mathrm{~mm}$ de largura e $8000 \mathrm{~mm}$ de comprimento (Figura 2.1). Elas são reaquecidas em temperatura por volta de $500{ }^{\circ} \mathrm{C}$ (homogeneização) e feita uma posterior redução na espessura destas placas para tiras de aproximadamente 4 a 6 mm, utilizando-se a etapa de laminação a quente (WOODWARD, 1994; MINATEL, 2009). Já no processo de lingotamento contínuo, devido às vantagens econômicas deste, nos últimos anos o seu uso está cada vez mais importante, pois a chapa metálica é produzida diretamente do metal fundido, com espessura já reduzida (aproximadamente 3 a $20 \mathrm{~mm}$ ), largura máxima de $2150 \mathrm{~mm}$ e com grandes comprimentos para o bobinamento direto (Figura 2.2), dispensando-se a laminação a quente (KAMMER, 1999).

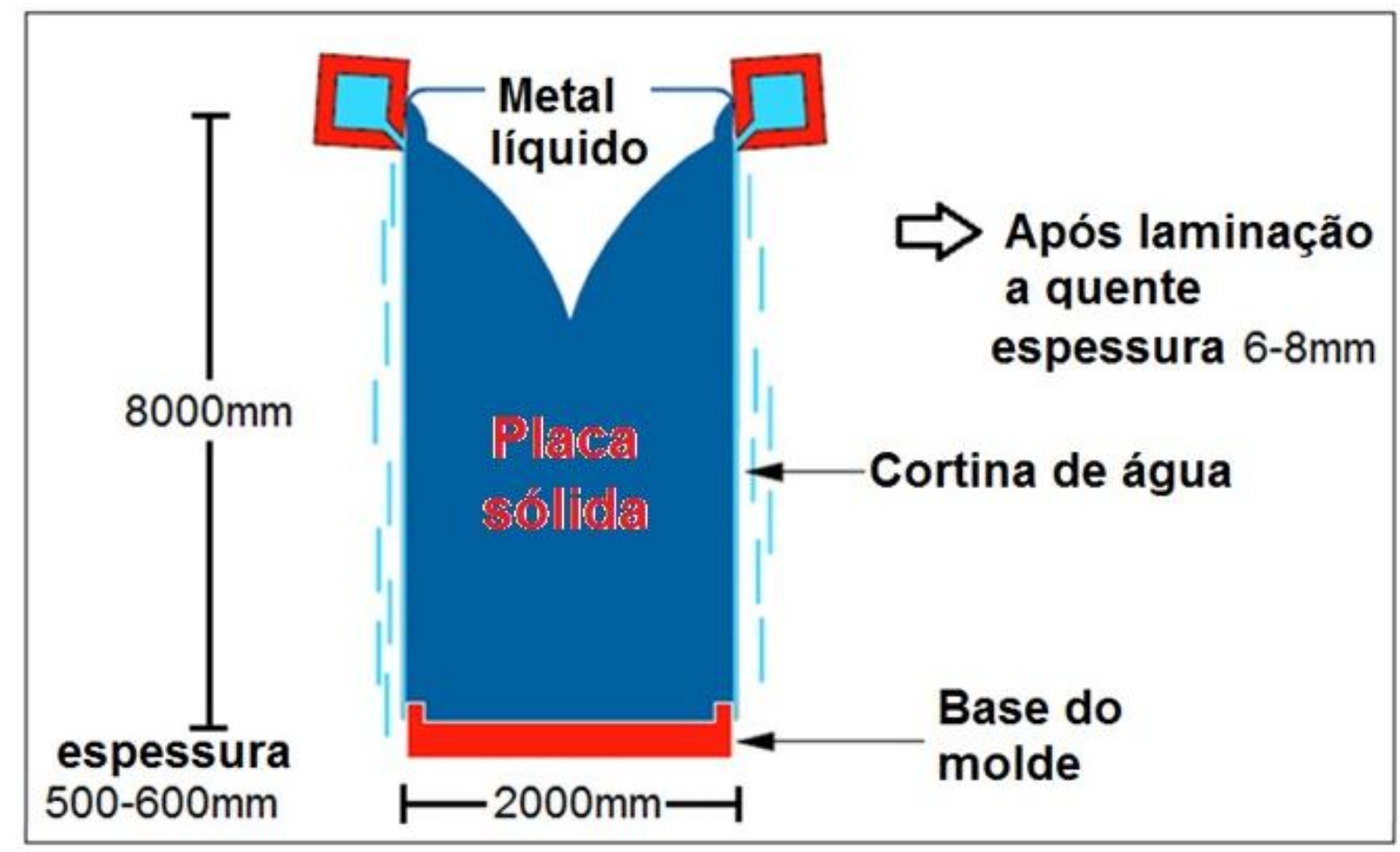

Figura 2.1 - Princípio esquemático da tecnologia de lingotamento semicontínuo (WOODWARD, 1994). 


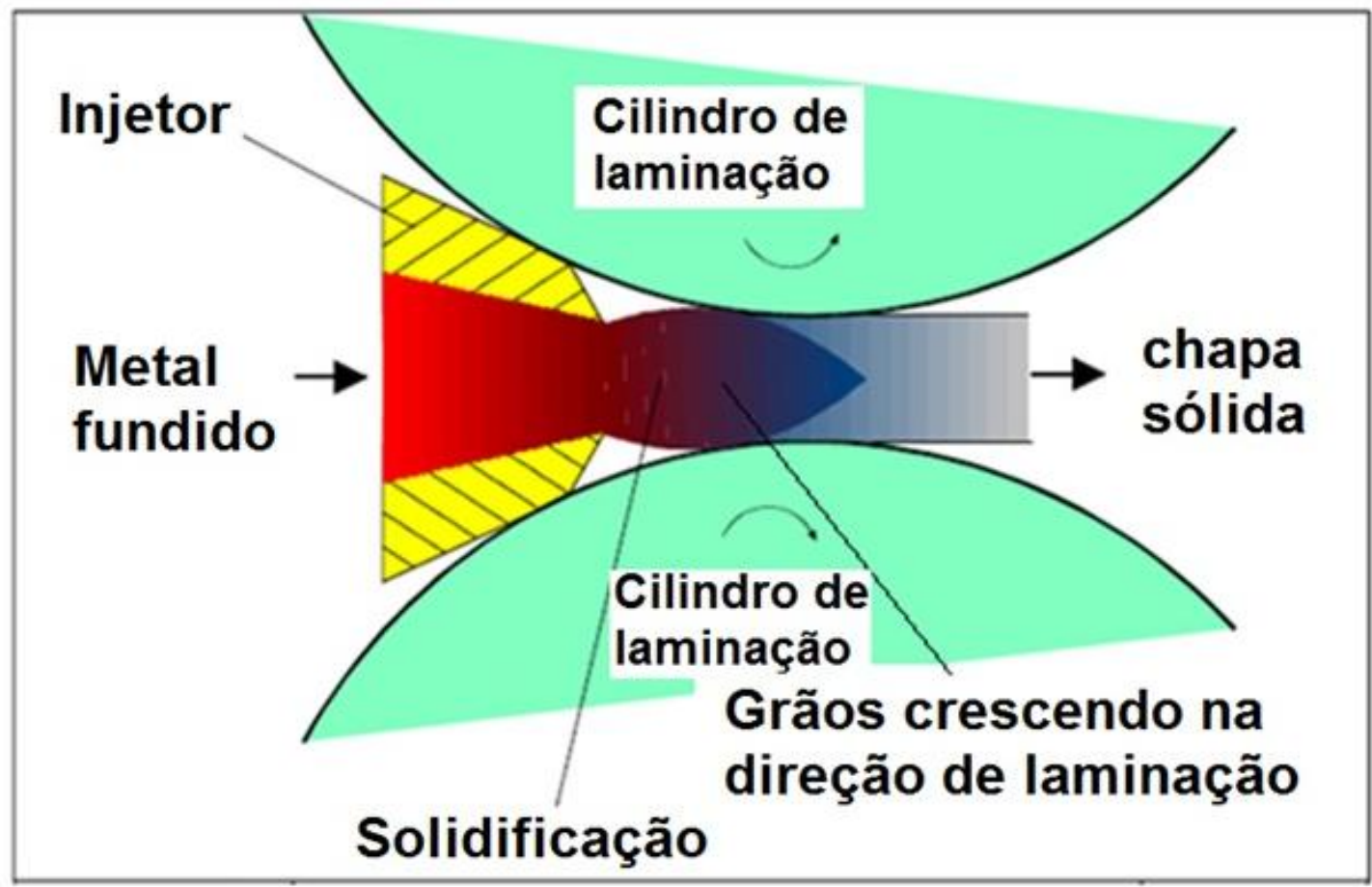

Figura 2.2 - Princípio esquemático da tecnologia de lingotamento contínuo (KAMMER, 1999).

Para a produção de tiras metálicas por lingotamento contínuo, usa-se o equipamento 'Caster' (equipamento de produção de chapas TRC), que por sua vez está equipado basicamente de um forno de fusão (onde a composição da liga é ajustada) e de um forno de espera (para a uniformização da composição). No 'Caster' encontra-se também um sistema de desgaseificação e limpeza do metal líquido, bem como uma calha que transporta o metal no estado líquido até o injetor, o qual distribui o metal uniformemente entre os cilindros de laminação (refrigerados com água), induzindo-se à solidificação da tira metálica na espessura da abertura entre os cilindros. $O$ injetor geralmente é composto de material cerâmico equipado com diversas peças que auxiliam na distribuição do metal líquido ao longo de toda sua extensão. Na região de solidificação (Figura 2.2), o volume de processamento da tira metálica pode ser dividido em três partes: zona líquida, zona pastosa e área de redução a quente ou zona sólida. Na zona liquida há a nucleação dos cristais de solidificação. Grandes quantidades desses cristais estão crescendo na zona pastosa. Na zona sólida há a deformação do metal solidificado entre os cilindros de laminação alongando os grãos na direção de laminação. No centro da chapa, na 
zona pastosa, ocorre a formação de grãos em forma de gota com estrutura que indica a nucleação de grãos na zona pastosa (FERNANDES, 2006).

É essencial lembrar que as necessidades de aplicação do alumínio, engajadas com o ensinamento, aprendizado e o desenvolvimento da engenharia do alumínio na indústria, apresentam grande relevância no desenvolvimento de novos produtos utilizando este material. Dessa forma, os aspectos como a fabricação, a resistência, as formas de uso e o desígnio do produto devem ser levados em consideração (OSTERMANN, 1999).

A combinação do alumínio com a maioria dos metais de engenharia (os chamados elementos de liga) é muito útil na utilização destes como elementos nas ligas de alumínio (por exemplo; na obtenção de materiais de construção mecânica), já que a resistência mecânica e outras propriedades das mesmas podem ser melhoradas com a adição de elementos de liga. Assim, através da análise da interrelação entre os elementos de liga e a aplicação do produto final é possível obter as características tecnológicas ajustadas de acordo com o uso de cada liga. Devido a isto, essas ligas são utilizadas na indústria, a fim de obter uma grande variedade de combinações otimizadas, envolvendo-se a resistência mecânica, a resistência à corrosão e ao ataque de substâncias químicas, a boa condutibilidade elétrica, a usinabilidade, a ductibilidade, a formabilidade, entre outros benefícios (DAVIS, 1993; ABAL, 1994). Como várias combinações de elementos de liga são possíveis, há a necessidade da classificação dessas ligas, conforme será discutido adiante.

A série $1 \mathrm{XXX}$ das ligas de alumínio classifica as ligas que apresentam no mínimo 99,00\% de pureza. O segundo dígito da nomenclatura de cada série (designado aqui por $1 \underline{\mathbf{X}} \mathrm{XX}$ ) indica modificações da liga original ou dos limites de impurezas. Os dois últimos dígitos $(1 \mathbf{X} \underline{\mathbf{X X}})$ identificam a liga de alumínio ou indicam a pureza do alumínio. As ligas dessa série são muito utilizadas na indústria elétrica, utensílios domésticos, defletores de calor, bem como em aplicações que apresentam resistência mecânica razoável e exigem boa conformabilidade. No que diz respeito ao comportamento mecânico das ligas de alumínio da série $1 \mathrm{XXX}$, não tratáveis termicamente, estas apresentam importante facilidade de conformação, de soldagem, boa condutividade elétrica, bom acabamento, além de apresentarem boa ductibilidade, porém apresentam resistência mecânica relativamente baixa. As ligas dessa série são ligas endurecíveis com o uso do trabalho mecânico (encruamento) (ABAL, 1994; ABAL, 2004). 
A série $2 \mathrm{XXX}$ envolve ligas que apresentam o $\mathrm{Cu}$ e algumas vezes $\mathrm{OMg}$ como os principais elementos de liga, elas são muito usadas na indústria aeronáutica, e são tratáveis termicamente, ou seja, endurecíveis por precipitação coerente (ABAL, 1994; ABAL, 2004).

A série $3 X X X$ inclui as ligas que apresentam o Mn como principal elemento de liga. Elas são muito utilizadas em aplicações como: construção civil, indústria de ônibus e baús e fabricação de latas de alumínio, bem como indústria de alimentos e bebidas. Elas apresentam média resistência mecânica e boa ductibilidade. Elas são ligas não tratáveis termicamente, endurecíveis por encruamento (ABAL, 1994; ABAL, 2004).

Já a série $4 X X X$ das ligas $\mathrm{Al}$ - Si têm propriedades mecânicas bem parecidas com as da série $3 X X X$. As ligas $A l-S i$ são ligas não tratáveis termicamente $e$ endurecíveis por encruamento (ABAL, 1994; ABAL, 2004). Recentemente, a produção de panelas de pressão com alta ductilidade, é possível, devido à introdução da liga AA4006 no mercado brasileiro (OTOMAR, 2010).

$\mathrm{Na}$ série $5 \mathrm{XXX}$ as ligas $\mathrm{Al}-\mathrm{Mg}$ podem alcançar um limite de resistência a tração de $400 \mathrm{MPa}$, isto é, o $\mathrm{Mg}$ proporciona um aumento significativo nas propriedades mecânicas do alumínio. Elas são utilizadas na indústria de transportes, indústria naval e outras. São ligas não tratáveis termicamente, endurecíveis por encruamento (ABAL, 1994; ABAL, 2004).

A série $6 \mathrm{XXX}$ inclui as ligas que apresentam o $\mathrm{Mg}$ e o $\mathrm{Si}$ como principais elementos de liga. Elas são muito utilizadas em projetos que envolvem extrusão. Elas apresentam média resistência mecânica e boa ductibilidade, e, são ligas tratáveis termicamente ou endurecíveis por precipitação coerente (ABAL, 1994; ABAL, 2004).

A série $7 \mathrm{XXX}$ engloba as ligas que apresentam o $\mathrm{Zn}, \mathrm{Mg}$ e $\mathrm{Cu}$ como elementos de liga. Elas são muito usadas em aplicações onde são solicitadas altíssimas propriedades mecânicas. Elas podem atingir limites de resistência a tração acima de $500 \mathrm{MPa}$, são tratáveis termicamente ou endurecíveis por precipitação (ABAL, 1994; ABAL, 2004; MONDOLFO, 1976).

$\mathrm{Na}$ série $8 \mathrm{XXX}$ estão incluídas as ligas que apresentam o $\mathrm{Si}$, Fe e $\mathrm{Mn}$ como elementos de liga. Elas são muito utilizadas na produção de folhas. (ABAL, 1994; ABAL, 2004; MONDOLFO, 1976). 
O trabalho a frio aumenta fortemente o limite de resistência à tração das ligas não tratáveis termicamente, por exemplo, o limite de resistência à tração da liga 3003 é aumentado de aproximadamente $110 \mathrm{MPa}$, na têmpera $\mathrm{O}$ (material recozido), para $200 \mathrm{MPa}$, na têmpera endurecimento por deformação H18 (material que sofreu deformação plástica a frio, para obtenção da resistência desejada, sem recozimento complementar e com um grau de encruamento de aproximadamente $75 \%$ de redução da seção transversal do material). Além disso, as ligas da série 3XXX apresentam melhores propriedades mecânicas que as do Al puro, já que este grupo de ligas tem boa resistência à corrosão e sua ductilidade é ligeiramente diminuída, devido à presença do Mn no material (DAVIS, 1993).

Algumas ligas de Al são largamente utilizadas em aplicações que envolvem o processamento por estampagem. Para a otimização desse processo faz-se um estudo da anisotropia das ligas laminadas, onde as propriedades mecânicas em diferentes direções no plano da chapa (anisotropia planar, parâmetro $\Delta R$ ) para a estampagem podem ser obtidas. A anisotropia plástica também pode ser avaliada levando em consideração as dimensões do corpo de prova do ensaio de tração, para a obtenção do parâmetro R. Assim, estes parâmetros são ajustados de forma a melhorar o processamento de produtos estampados (VIAL; HOSFORD; CADDELL, 1983). O ensaio de orelhamento também pode ser utilizado para avaliar a anisotropia na estampagem (ENGLER; HIRSCH, 2007). As ligas AA4006 e AA4007 apresentam alto desempenho na produção de utensílios de cozinha com recobrimento de politetrafluoretileno PTFE (HOFFMANN; CORTES, 2003). É relevante ressaltar que no processo de solidificação do alumínio e suas ligas ocorre o surgimento e a mudança de diferentes fases cristalinas que apresentam características diversificadas durante o processo de resfriamento. Neste contexto, torna-se importante discorrer sobre o processo de solidificação e o sistema ternário Al-Fe-Si, já que a liga de alumínio estudada nesse trabalho apresenta o $\mathrm{Si}$ e o $\mathrm{Fe}$ como elementos de liga.

\subsection{O processo de solidificação e o sistema Al-Fe-Si}

No processo de resfriamento (utilizando o processo de produção de chapas $T R C$ ), partículas com diâmetros de poucos $\mu \mathrm{m}$ (refinadores de grãos), são inseridas como 'sementes' de nucleação para o crescimento. Quando a velocidade de 
crescimento dos grãos é maior numa direção, surge o crescimento dendrítico, onde três patamares no espaço tridimensional são formados e chamados de braços da dendrita (STØREN, 1994).

A análise das microestruturas dendríticas, provenientes dos processos de lingotamento, é muito importante, devido à forte relação de dependência existente entre o espaçamento e entre os braços das dendritas que compõem a microestrutura, já que microestruturas dendríticas mais finas conferem melhores propriedades mecânicas ao material do que microestruturas dendríticas mais grosseiras (MONDOLFO, 1976). Dessa forma, diversos pesquisadores têm estudado a estrutura dendrítica, a fim de caracterizar o espaçamento (entre os braços primários e secundários das dendritas) em função da concentração de soluto presente na liga, bem como, em função da taxa de crescimento da ponta da dendrita e do gradiente de temperatura da frente de solidificação macroscópica (PERES et al, 2004; STØREN, 1994). Assim, o crescimento dendrítico dos cristais (grãos) em ligas de alumínio pode ocorrer durante o resfriamento do metal, no processo de obtenção das peças metálicas por lingotamento.

É relevante lembrar que as propriedades do metal solidificado são, fortemente, influenciadas pelo tamanho de grão, espaçamento da dendrita, poros e quantidade de impurezas (PERES et al, 2004; STØREN, 1994). Vale ressaltar que durante o resfriamento do alumínio e suas ligas pode ocorrer também o surgimento de tensões internas que levam ao aparecimento de trincas, resultando-se na fragilidade da peça na região dessas trincas.

Os diagramas de fases ternário Al-Fe-Si e binário Al-Si podem ser utilizados para estudar, controlar e localizar diferentes fases sólidas com a combinação de seus respectivos elementos em equilíbrio termodinâmico. Neste contexto, as ligas com composições próximas de $100 \%$ de alumínio, e localizadas na região rica em Al, podem apresentar diferentes fases em suas microestruturas. Como pode ser visto na Figura 2.3, na região menor que $2 \%$ em peso de Si e com o Fe fixado em $0,7 \%$, as diferentes fases ternárias $\mathrm{Y}\left(\mathrm{FeAl}_{3} \mathrm{Si}_{3}\right)$, $\alpha\left(\mathrm{Fe}_{2} \mathrm{Al}_{7,4} \mathrm{Si}\right)$ e $\beta\left(\mathrm{Fe}_{2} \mathrm{Al}_{9} \mathrm{Si}_{2}\right)$ juntamente com a fase binária $\mathrm{Al}_{3} \mathrm{Fe}$ podem ocorrer na matriz de $\mathrm{Al}$. Convém ressaltar, que as soluções sólidas ricas em alumínio podem dissolver aproximadamente 0,052 \% em massa de $\mathrm{Fe}(\mathrm{GHOSH}, 1992)$. As regiões de ocorrência das fases ternárias, no estado sólido, estão, em sua maioria, fora da faixa da cristalização primária, e, a finalização das reações peritéticas é necessária para o 
equilíbrio ser estabelecido. Por esta razão, na maioria das ligas comerciais, o sistema (composto pelos constituintes do material) pode não estar em equilíbrio, e, é comum encontrar ligas nas quais há a presença das fases $\mathrm{FeAl}_{6}, \mathrm{FeAl}_{3}, \mathrm{Fe}_{2} \mathrm{Al}_{8} \mathrm{Si}$, $\mathrm{FeAl}_{5} \mathrm{Si}$ e $\mathrm{FeAl}_{4} \mathrm{Si}_{2}$, que podem coexistir com outras fases e com o Si. No entanto, ainda não há dados completos das secções politérmicas na projeção solidus do sistema Al-Fe-Si. (GHOSH, 1992; ALLEN et al, 1998).

A Figura 2.3 apresenta o diagrama ternário Al-Fe-Si, com a quantidade de Fe em massa fixa em 0,7\%, quantidade similar às das chapas da liga AA4006 pesquisadas neste trabalho (MONDOLFO, 1976). Algumas fases intermetálicas podem surgir, caso o resfriamento ocorra em equilíbrio.

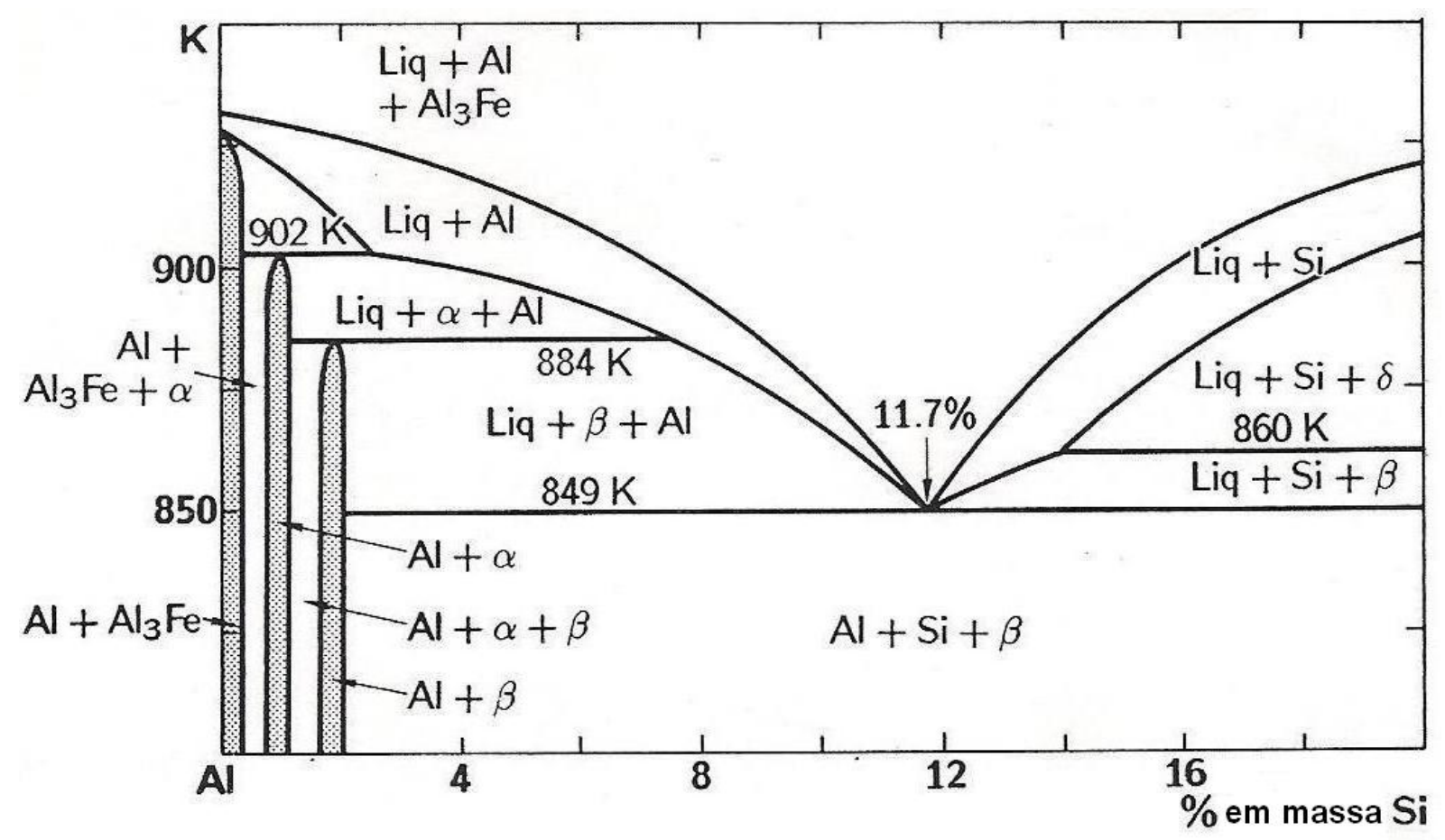

Figura 2.3 - Diagrama ternário Al-Fe-Si no canto rico em Al com a quantidade de Fe fixa em 0,7 \% em massa (GHOSH, 1992; MONDOLFO, 1976).

Vale lembrar que o Si é conhecido como um soluto de solubilidade intermediária (> 1 e $<10 \%$ atômico), já o Fe como um soluto de solubilidade baixa (<1\% atômico) (PADILHA; PLAUT, 2003). É interessante ressaltar que em ligas de Al-Fe-Si endurecidas por envelhecimento, o silício precipita nos planos (100) e (111), na rede do $\mathrm{Al}$, e, $\mathrm{FeAl}_{3}$ como agulhas nos planos (110) da matriz (GHOSH, 1992). Convém lembrar aqui que a migração de contornos de alto ângulo, durante o 
recozimento de ligas de alumínio brutas de fundição induz à redistribuição de soluto por difusão ao longo do contorno de grão (FALLEIROS, 1972).

Portanto, após esta análise microestrutural de seus constituintes, e, sabendose que 0 tratamento térmico e 0 tratamento mecânico podem mudar a microestrutura, torna-se relevante fazer uma abordagem sobre o processamento termomecânico do material tratado e suas mudanças nas propriedades estruturais.

\subsection{Fatores que afetam a estrutura dos metais deformados}

O conhecimento da ocorrência de defeitos microestruturais envolvendo os constituintes da estrutura de um metal é de fundamental importância para a compreensão de suas mudanças microestruturais. Alguns defeitos puntiformes são causados por átomos de soluto dissolvidos na matriz (impurezas substitucional e intersticial), além disso, eles podem aumentar a resistência mecânica de uma liga (endurecimento por solução sólida). Num cristal, a deformação plástica, quando há a movimentação ou o rearranjo de alguns átomos de uma parte (no plano cristalino) deste cristal que deslizou e uma parte que não deslizou, ocorre com a participação de uma discordância (defeito de linha). $\mathrm{O}$ aumento da quantidade de discordâncias na estrutura do metal melhora sua resistência mecânica, enquanto que, a presença de poros, trincas e inclusões (defeitos de volume) podem diminuir a resistência do metal (PADILHA, 2000).

Os planos arranjados, seqüencialmente, na estrutura cristalina podem apresentar alterações locais, devido à deformação plástica, assim como devido à aglomeração de defeitos puntiformes. Assim, defeitos de empilhamento, que são limitados por discordâncias parciais, podem surgir num arranjo de planos. A energia de defeito de empilhamento (EDE) pode ser medida experimentalmente através das medidas das distâncias entre as discordâncias parciais. Um metal com baixa EDE, após deformação plástica, tem maior densidade de discordâncias com distribuição mais uniforme, tem também, uma maior energia armazenada na deformação, apresentando, geralmente, maior taxa de encruamento, uma maior resistência à fluência e uma considerável suscetibilidade à corrosão sob tensão, quando comparado com um material com EDE alta (alumínio, por exemplo) e deformado nas mesmas condições (PADILHA, 2000). Vale ressaltar que os valores de EDE dos metais ainda não são valores definitivos, já que para a obtenção da EDE de um 
metal ou de uma liga diferentes métodos de determinação podem gerar variados valores de EDE para cada material (CAMPOS; FARIAS; PADILHA, 1999).

Em um policristal, durante a deformação plástica, ocorre a mudança de forma e de orientação dos grãos, podendo-se adquirir orientação preferencial (textura de deformação), há também, o aumento da quantidade dos contornos de grão por unidade de área, bem como o aumento significativo da quantidade de defeitos puntiformes e de discordâncias por unidade de volume (PADILHA; SICILIANO, 2005).

Num metal de baixa EDE as discordâncias apresentam baixa mobilidade, devido ao afastamento médio entre as discordâncias parciais, as quais tendem a ter uma distribuição homogênea na estrutura do metal. De outra forma, metais com alta EDE, apresentam discordâncias parciais próximas umas das outras com alta mobilidade, que tendem a se movimentarem em planos de baixos índices de Miller, e, eventualmente, se anularem com outras discordâncias de sinal oposto. Assim, a distribuição das discordâncias ocorre de forma heterogênea, havendo-se a formação de células de deformação, também denominadas células de discordâncias, no interior do grão (PADILHA; SICILIANO, 2005).

A EDE é alterada quando átomos de soluto são adicionados em um metal puro, influenciando-se na distribuição e na mobilidade das discordâncias, havendose, também, um aumento gradativo na densidade de discordâncias e da energia armazenada na deformação, bem como, levando-se à diminuição gradativa do tamanho médio das células de deformação. Contudo, evidências mostraram que a densidade de discordâncias pode assumir valores maiores em grãos de tamanhos menores, e, que a temperatura de deformação do metal influencia na distribuição e na densidade de discordâncias, bem como na energia armazenada na deformação. Dessa forma, temperaturas decrescentes, na deformação, causam a diminuição da mobilidade das discordâncias e a diminuição da EDE do metal, contribuindo também, para a formação de células (subgrãos) menores e menos definidas. É relevante lembrar que pequenas variações na temperatura de deformação levam a grandes mudanças na subestrutura de discordâncias, a qual é menos influenciada pela velocidade de deformação (PADILHA; SICILIANO, 2005).

A resistência mecânica de um metal pode ser melhorada, utilizando-se técnicas de processamento que envolvam os mecanismos de endurecimento por deformação ou encruamento (produção de outras discordâncias), de endurecimento 
por solução sólida (envolvendo átomos de soluto), de endurecimento por precipitação (precipitados coerentes com a matriz), de endurecimento por dispersão (precipitados incoerentes com a matriz) e de endurecimento por refino de grão (diminuição do tamanho de grão envolvendo os contornos de grão e de subgrão) (PADILHA, 2000). Os fatores que afetam a microestrutura dos metais deformados podem gerar heterogeneidades e mudanças na estrutura do material durante os processos de deformação, como será abordado a seguir.

\subsection{Evolução microestrutural durante a deformação e suas heterogeneidades}

As ligas de alumínio comercial (Al-Fe-Si) são exemplos típicos de ligas que não são endurecidas por precipitação, onde os elementos de liga ou impurezas são encontrados como precipitados de segunda fase. O alumínio puro apresenta uma EDE relativamente alta, devido a isto, quando ele é submetido ao trabalho a frio, pequena parte da energia empregada é armazenada na forma de defeitos de rede. Assim, uma subestrutura celular pode ser formada, já que a densidade e a distribuição desses defeitos acontecem de forma heterogênea como ocorre nas ligas de alumínio. Dessa forma, o alumínio e suas ligas podem apresentar grandes heterogeneidades na distribuição de seus defeitos de rede, chamadas de bandas de deformação, onde acontece preferencialmente o inicio da recristalização (nucleação) (PADILHA, 2000).

As bandas de deformação (bandas de transição) presentes na estrutura deformada de um metal são formadas por partes de um mesmo grão que sofreram rotações diferentes (com diferenças de orientações) em sistemas de escorregamento de planos cristalinos distintos. Já, na formação das bandas de cisalhamento ocorre o escorregamento de planos cristalinos em regiões de máxima tensão macroscópica de cisalhamento, bem como nos planos de menor resistência à deformação. Esse tipo de heterogeneidade não se limita a um determinado grão (PADILHA; SICILIANO, 2005).

Em metais deformados, utilizando-se os processos como laminação, forjamento, tensão, compressão e carregamento cíclico, pode haver a ocorrência desses tipos de heterogeneidades. Vale lembrar que as bandas de cisalhamento podem se formar no material como um todo, e sua ocorrência depende muito da velocidade, da quantidade e do modo de deformação. Já as bandas de transição se 
formam devido às diferenças de deformação a nível microestrutural, e, são delimitadas por cada grão individual (PADILHA; SICILIANO, 2005).

Outra forma muito conhecida de mudança microestrutural, ou heterogeneidade na deformação plástica, é a maclação mecânica. Ela surge quando a deformação se torna muito difícil por deslizamento de planos cristalinos em cada grão, devido à restrição do número de sistemas de escorregamento desses planos, assim como, devido às deformações a altas velocidades e a baixas temperaturas. Na maclação mecânica ocorrem pequenos movimentos coordenados de átomos, e, ela raramente se forma em metais de estrutura cúbica de face centrada. É relevante ressaltar que essas heterogeneidades desempenham um importante papel no início da recristalização em metais (PADILHA; SICILIANO, 2005). A ocorrência de maclas de recozimento e/ou de deformação, em metais com estrutura cristalina CFC, e alta EDE (como alumínio e suas ligas) é pouco freqüente e pouco relevante.

\subsection{O tratamento térmico de homogeneização e a laminação a quente}

A recristalização pode ser vista como uma mudança (transformação) de fases envolvendo a nucleação e o crescimento durante o recozimento de um metal deformado plasticamente. A diminuição da quantidade de defeitos puntiformes, a aniquilação de discordâncias, o encolhimento de anéis de discordâncias, o rearranjo de discordâncias para configurações de menor energia e a formação de contornos de grão de alto ângulo são classificadas como modificações da microestrutura do metal que ocorrem na recuperação. Enquanto, a absorção de defeitos puntiformes e de discordâncias por contornos de alto ângulo, e o aumento da área total dos contornos de grãos no refinamento de grão, são modificações que ocorrem na recristalização, já no crescimento de grão, há a redução da área total dos contornos de grãos num determinado volume (RIOS et al, 2005).

Durante a movimentação ou o rearranjo da interface transformada/nãotransformada, através da transferência de átomos, há a formação de uma região livre de defeitos (núcleo) circundada por um contorno de alto ângulo. Durante o crescimento desse núcleo, através da migração do contorno de alto ângulo sobre a matriz encruada (deformada), há a ocorrência da recristalização de forma a eliminar os defeitos cristalinos, já que o potencial termodinâmico para a recristalização é a energia armazenada na deformação (DOHERTY, 1997; PADILHA; SICILIANO, 
2005). Convém lembrar que a geração de novos contornos de alto ângulo pode ocorrer através da migração de contornos de baixo ângulo (subcontornos) ou pela coalescência ou rotação de subgrãos (PADILHA; PLAUT, 2003).

Estes fenômenos mudam, completamente, a microestrutura de uma peça metálica bruta de fusão e/ou vazada em placas (com estrutura dendrítica, por exemplo). A mudança microestrutural ocorre também devido à distribuição dos elementos de liga, por difusão, de forma mais homogênea na microestrutura, e, novos grãos, com forma diferenciada da microestrutura anterior, aparecem (STØREN, 1994). Dessa forma, este efeito de recozimento do material leva à diminuição da dureza do mesmo, influenciando-se as suas propriedades mecânicas. O efeito da homogeneização na recristalização da liga de alumínio AA4006 foi estudado por Lee e Yeung (1998). Eles reportaram que, após a homogeneização, a temperatura de recristalização pode ser afetada de forma significativa, o que facilita o trabalho a frio. Para a homogeneização, os autores sugeriram a temperatura de $600{ }^{\circ} \mathrm{C}$ e uma duração de 12 horas (YEUNG; LEE, 1998).

Durante o tratamento térmico do material metálico, os processos de recuperação (nas micro-regiões menos deformadas) e recristalização (nas microregiões mais deformadas) podem ocorrer simultaneamente, pois os fenômenos de distribuição heterogênea de defeitos cristalinos e a competição entre recuperação e recristalização, freqüentemente, se relacionam. Assim, nos materiais com alta EDE, há a facilidade de ocorrência da recuperação nas regiões ainda não recristalizadas, e, em materiais de baixa EDE a recuperação é quase não detectada, devido à acentuada ocorrência de recristalização. Neste contexto, na Figura 2.4, pode ser visto que o cobre (de EDE menor) quase que, unicamente, amolece por recristalização, por outro lado, o alumínio (de EDE maior) apresenta uma grande parte do seu amolecimento por recuperação (PADILHA; SICILIANO, 2005). 


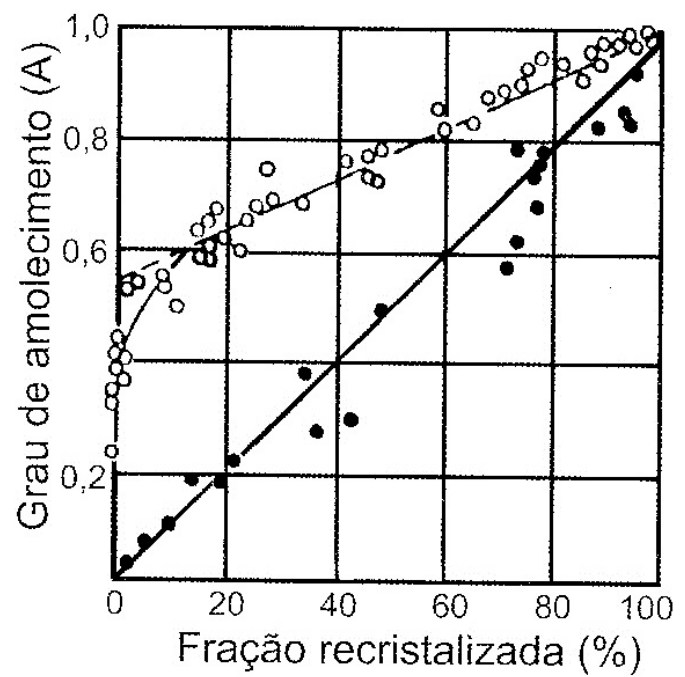

Figura 2.4 - Relação entre a fração amolecida e a fração recristalizada para o alumínio (cujo símbolo na figura é ${ }^{\circ}$ ) e para o cobre (cujo símbolo na figura é •) (PADILHA; SICILIANO, 2005).

A recuperação dinâmica e a recristalização dinâmica ocorrem no material metálico quando o mesmo está submetido à deformação a quente. Dessa forma, o encruamento, a recuperação e a recristalização contribuem para as alterações microestruturais simultâneas que ocorrem no material. Na recuperação dinâmica, o número de defeitos cristalinos aumenta durante a deformação a quente, permitindo, em um dado momento, que a quantidade de defeitos gerados seja compensada pela quantidade de defeitos eliminados, atingindo-se um estágio estacionário de estabilização da tensão (steady state stress), na curva tensão-deformação a quente (Figura 2.5a). Metais de alta EDE, como o alumínio, apresentam rápida cinética de recuperação dinâmica, a qual contribui para a diminuição do potencial termodinâmico para a recristalização, possibilitando-se, de forma mais provável, a recuperação dinâmica. Em metais de baixa EDE a cinética de recuperação é lenta mantendo-se a quantidade de defeitos sempre alta no decorrer da deformação, favorecendo-se a recristalização dinâmica, já que existe potencial termodinâmico suficiente (Figura 2.5b) (PADILHA; SICILIANO, 2005). 


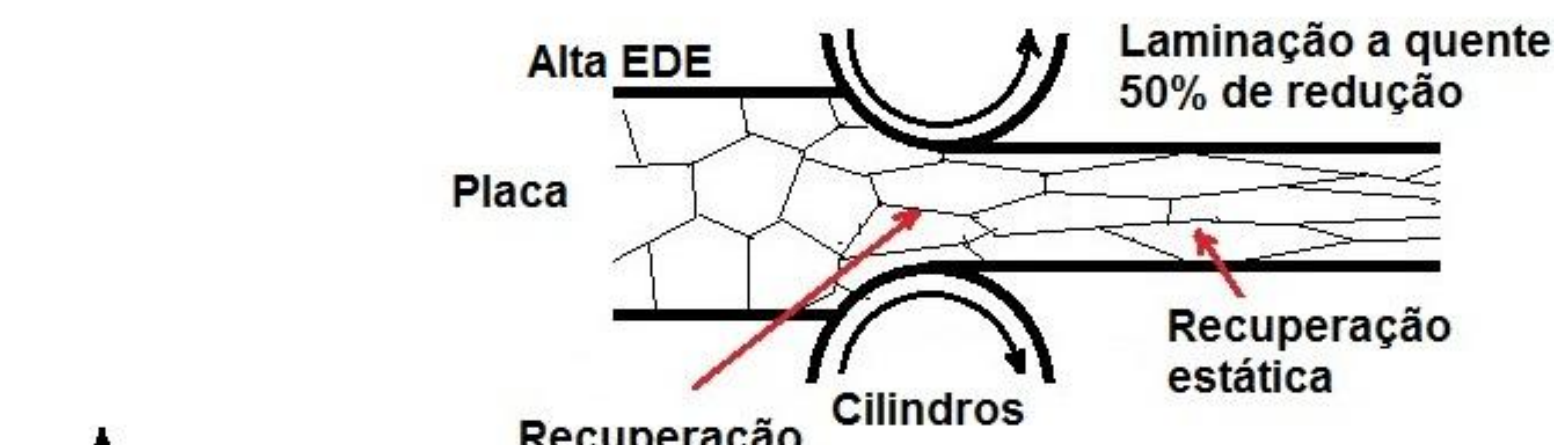

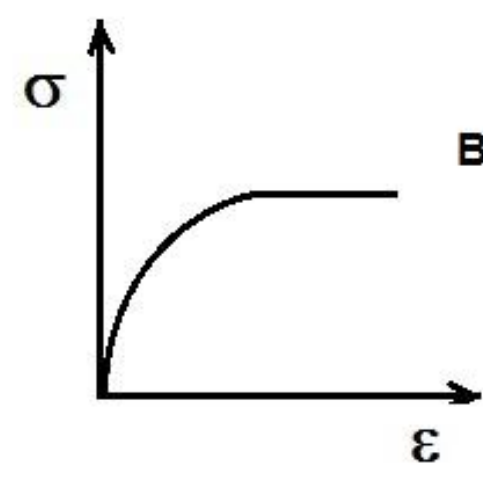

(a)
Recuperação dinâmica
Cilindros

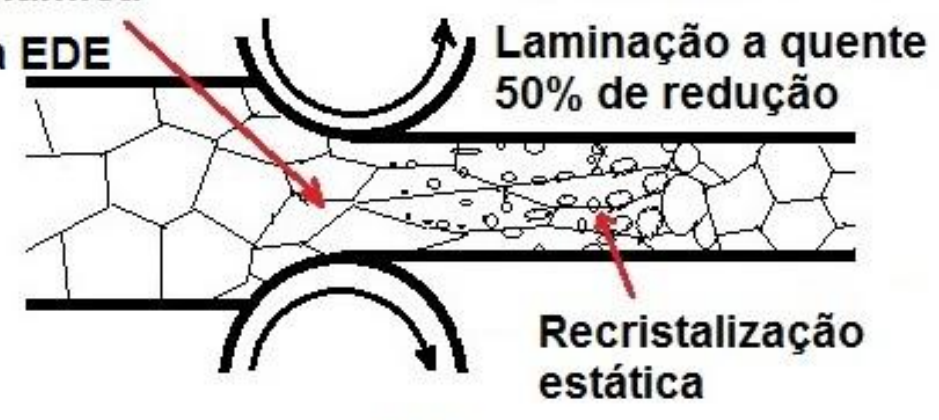

(b)

Figura 2.5 - (a) Curva tensão-deformação a quente com ocorrência somente de recuperação dinâmica. Mecanismos de restauração (recuperação e recristalização) possíveis durante a recuperação a quente (b) na laminação em baixas deformações para metais com alta EDE e baixa EDE (PADILHA; SICILIANO, 2005).

A adição de soluto em um metal pode causar a diminuição de sua EDE, bem como causar a formação de atmosferas de soluto próximo às discordâncias, diminuindo-se a mobilidade das mesmas. A recristalização pode iniciar de forma dinâmica, e após a deformação do material, os grãos podem continuar a crescer de forma estática, com ausência de tensões. Esse fenômeno é conhecido como recristalização metadinâmica, no qual os núcleos surgem durante a deformação e crescem após a ausência de trabalho mecânico. Vale ressaltar que a curva da tensão média de escoamento TME em função do inverso da temperatura é muito útil para estudar um material aquecido e conformado, já que as transformações microestruturais, que ocorrem simultaneamente, podem ser detectadas e conseqüentemente analisadas.

Em outros estudos foi relatado que o amaciamento do alumínio de alta pureza ocorre devido à recristalização durante a deformação. Um estado estacionário mecânico (steady state) também foi estudado, anteriormente, e visto como um 
balanço entre a recuperação dinâmica e o encruamento do material (KASSNER et al, 1994). Dessa forma, durante as etapas de fabricação dos metais (lingotamento contínuo e lingotamento semi-contínuo para ligas de $\mathrm{Al}$, por exemplo) no processo de deformação a quente pode haver a ocorrência dos mecanismos de restauração. Logo, as alterações microestruturais simultâneas que ocorrem no material são decorrentes dos processos de recuperação dinâmica e recristalização dinâmica.

\subsection{Recuperação e recristalização de ligas metálicas}

A velocidade de migração do contorno de alto ângulo, na recristalização, pode variar com a diferença de orientação cristalográfica entre os grãos (ângulo de desorientação). Assim, a velocidade de migração dos contornos pode ser descrita pela relação:

$V=m \Delta P$

onde $m$ é a mobilidade do contorno, a qual pode ser medida utilizando a técnica de Raios X (GOTTSTEIN et al, 1995), e $\Delta P$ o potencial termodinâmico para a recristalização, o qual pode ser medido por calorimetria. Como já reportado na literatura, o potencial termodinâmico devido ao encruamento, o potencial termodinâmico devido aos contornos de grão, o potencial termodinâmico devido à precipitação descontínua e as forças retardadoras devido a partículas e a átomos de soluto são as principais forças que podem atuar na frente de reação (migração de contornos) na recristalização. A força retardadora devido a partículas (dispersão de precipitados) atua aplicando uma pressão oposta à migração dos contornos. A força retardadora devido a átomos de soluto pode ser entendida, de forma geral, como uma aproximação do modelo que envolve o mecanismo da força retardadora devido a partículas (RIOS et al, 2005).

As impurezas ou elementos de liga podem ser vistas na matriz como microestruturas compostas de solução sólida (microestrutura monofásica) e compostas de solução sólida supersaturada, podendo-se precipitar-se durante o recozimento. Elas podem ser vistas também como uma dispersão de precipitados 
indeformáveis em relação à matriz, bem como na forma de uma segunda fase de elevada fração volumétrica, onde ambas as fases são deformáveis (microestrutura dúplex). Vale lembrar que os elementos de liga podem conduzir à formação de uma microestrutura que se recristaliza em fases ordenadas.

A diminuição da energia de defeito de empilhamento de um metal, o aumento da dificuldade do movimento e rearranjo de discordâncias, bem como 0 aparecimento de uma força retardadora que dificulta o movimento de contornos (formados por discordâncias) são fenômenos que podem ocorrer devido à adição de soluto em uma matriz metálica. Isto retarda o início da recristalização, já que a formação de células de deformação e a formação de grandes diferenças de orientação no reticulado cristalino, que contribuem para a nucleação, ficam prejudicadas, devido ao aumento da força motriz para a recristalização e da densidade de discordâncias.

Durante, antes e após a recristalização de uma liga, numa solução sólida supersaturada, pode ocorrer precipitação de partículas de segunda fase numa determinada temperatura quando o tempo é crescente. Assim, a precipitação de partículas antes da recristalização influi no rearranjo de discordâncias durante a recuperação e na migração de contornos de grão, e, o diagrama ou curva TTT é essencial para a interpretação destes fenômenos (PADILHA; SICILIANO, 2005).

As ligas de Al apresentam considerável quantidade de elementos de liga em sua constituição como elementos formadores de partículas. Neste sentido, o diâmetro médio das partículas e o espaçamento entre elas influenciam diretamente na deformação e na recristalização de uma liga. Uma liga com dispersão de partículas grosseiras apresenta uma densidade de discordâncias maior que numa liga isenta de partículas. Dessa forma, quanto maior a distância entre os precipitados mais alta é a desorientação no reticulado, e a nucleação da recristalização é favorecida em torno da partícula. A recristalização é acelerada se o espaçamento interpartículas for grande o suficiente para não interferir muito na movimentação de subcontornos e na formação do núcleo, já que a fração volumétrica de partículas é aumentada. No entanto, partículas finas com diâmetro médio menor que $1 \mu \mathrm{m}$ e distribuídas homogeneamente levam ao aumento da distribuição de defeitos ancorando os subcontornos, e conseqüentemente, dificultando a nucleação da recristalização. Vale ressaltar que a nucleação nas vizinhanças das partículas depende do grau de deformação do metal e do diâmetro da partícula, isto é, para um 
alto percentual de redução pode haver a nucleação em partículas menores ( 3 $\mu \mathrm{m})$ e para baixos percentuais a partícula precisa ser grande (> $10 \mu \mathrm{m})$ para ocorrer nucleação (RIOS et al, 2005; PADILHA; PLAUT, 2003).

Conforme Zener, a força máxima de resistência por unidade de área do contorno que uma partícula esférica exerce no mesmo dificultando o seu movimento, é diretamente proporcional à fração de volume da partícula $F_{v}$ e inversamente proporcional ao raio $r$ da mesma, conforme a equação:

$F_{\max }=\frac{3}{4}\left[\gamma\left(\frac{F_{V}}{r}\right)\right]$

Assim, a resistência ao movimento do contorno, devido ao precipitado, é proporcional ao fator $\frac{F_{V}}{r}$, e $\gamma$ é a energia de superfície do contorno (PADILHA; PLAUT, 2003). Em 1987, Rios reportou que há um segundo mecanismo com uma força retardadora maior que a força calculada por Zener (RIOS, 1987):

$F_{p}=\left(3 \gamma \frac{F_{V}}{r}\right)$

Na recristalização dinâmica pode haver a ocorrência de refino de grão ou de engrossamento de grão, já que as mudanças no tamanho de grão final dependem do tamanho de grão inicial (PADILHA; SICILIANO, 2005). Vale ressaltar que vários autores (HUMPHREYS, 1977; ENGLER; VATNE; NES,1996; ENGLER, 1997; DOHERTY, 1997; ENGLER; HIRSCH, 2002) estudaram a interdependência que há entre os precipitados e as texturas cristalográficas presentes em diferentes matrizes metálicas (como por exemplo, o desenvolvimento de uma textura específica através da nucleação estimulada por partículas de segunda fase em chapas de Al). Portanto torna-se interessante discorrer sobre a textura cristalográfica em ligas de alumínio.

\subsection{Importância da textura cristalográfica nos metais}

Agregados policristalinos, em metais com orientações distribuídas aleatoriamente (ausência de textura cristalográfica), são raramente encontrados, já 
que a textura de um metal ou liga se desenvolve durante uma ou mais operações de processamento e obtenção (como fundição, conformação mecânica e recozimento). A textura de deformação ocorre durante uma conformação mecânica, devido ao escorregamento de determinados planos cristalinos, os quais mudam a orientação cristalográfica durante a deformação, causando a rotação do reticulado cristalino. Esta rotação ocorre devido ao escorregamento de planos, ou por maclação, favorecendo-se orientações especificas (PADILHA; SICILIANO, 2005).

Dentre os principais tipos de textura, a textura de chapa é analisada através da observação da orientação da maioria dos grãos, em um determinado plano cristalográfico (hkl), aproximadamente, paralelo ao plano da superfície da chapa e com uma determinada direção [uvw] do plano (hkl), aproximadamente, paralelo à direção de laminação. Agregados policristalinos podem apresentar precipitados grosseiros $(>1 \mu \mathrm{m})$ antes da deformação, que levam ao aparecimento de uma textura ao acaso, ou seja, textura cristalográfica muito fraca (LÖW, 2000).

Vale ressaltar que o estudo do controle da textura de cada liga pode levar à compreensão da aplicação prática desta liga, bem como conduzir à obtenção de conclusões importantes sobre os mecanismos de mudança da microestrutura policristalina envolvidos nos processos térmicos e mecânicos durante a produção e otimização das propriedades do alumínio e de suas ligas. Por isso, a textura é uma ferramenta muito importante para o estudo dos mecanismos que ocorrem nos processos metalúrgicos (deformação plástica, recristalização, solidificação, etc.) (HJELEN; ORSUND; NES, 1991; LÜCKE; ENGLER, 1990). Como pode ser observado, a textura cristalográfica contém informações sobre o histórico de produção do material e de seu posterior desempenho (STÜWE; FAUSTMANN, 1969; SOUZA et al, 2011).

Os métodos de difração de raios $X$, nêutrons ou elétrons podem ser utilizados para investigar a textura cristalográfica. A técnica de difração de raios $X$ é a mais utilizada, já que ela permite a análise de um número grande de grãos em amostras com dimensões razoáveis (com áreas da ordem de $\mathrm{mm}^{2}$ ), além de ser relativamente rápida e barata. A partir da análise de difração por raios $X$, ou pela técnica de EBSD, pode ser obtida a Função de Distribuição de Orientações $f(g)$ que é calculada a partir de figuras de pólos diretas. Ela pode ser representada graficamente por seções com $\varphi_{2}$ constante e com curvas de níveis de mesmo valor, a fim de obter a interpretação através dos ábacos em diferentes graus. 
Durante a deformação a frio das ligas de alumínio a forma do grão inicial é transformada numa forma microestrutural de grãos alongados com orientações preferenciais. Assim, é muito comum o aparecimento de diversas texturas de deformação e de recristalização, que ocorrem a partir de processos que dependem da deformação mecânica no processamento de chapas metálicas. Esta diversificação pode ocorrer também devido à composição da liga e da variação da temperatura de recristalização. Vale ressaltar que as principais componentes de textura de laminação e de recristalização observadas em ligas de alumínio são cobre, S, Goss, cubo, R, P e Q (ENGLER; LÜCKE, 1992; DOHERTY, 1997).

Utilizando um difratômetro de raios $X$ e uma fonte de radiação monocromática, as intensidades dos picos de difração de uma amostra que apresenta textura são comparadas com as intensidades dos respectivos picos de uma amostra praticamente isenta de textura, e determinadas, experimentalmente, utilizando-se uma amostra na forma de pó compactado. As intensidades também podem ser calculadas com excelente precisão, utilizando-se fórmulas e fatores adequados (CULLITY; STOCK, 2001; KLUG; ALEXANDER, 1974). A textura pode ser determinada, experimentalmente, pelos métodos de transmissão e de reflexão. No presente trabalho foi utilizado o método de reflexão mostrado na Figura 2.6. Um goniômetro de textura é acoplado a um difratômetro de raios X. Desta forma, temos quatro graus de liberdade representados pelos ângulos $(\theta, \phi, \chi$ e $\omega)$. $O$ feixe de raios $X$ é incidido na amostra submetida às rotações dos eixos perpendiculares $\phi$, $\chi$ e $\omega$, onde o eixo $\omega$ coincide com o $\theta$ (Figura 2.6). Na geometria de reflexão, a amostra com superfície plana e polida é posicionada em um porta amostras com a direção normal paralela ao eixo de rotação $\phi$. Então, a amostra é girada em torno de seu próprio plano, ao redor do eixo normal $\phi$, dessa forma, 0 ângulo $\phi$ corresponde ao ângulo de rotação azimutal $\beta$ de um pólo da figura de pólo. Ao completar esta rotação, a amostra é inclinada ao redor do eixo $\chi$, o qual está relacionado ao ângulo de rotação radial $\alpha\left(\alpha=90^{\circ}-\chi\right)$, já que $\chi$ e a figura de pólo do ângulo radial a são definidos na direção oposta (RANDLE; ENGLER, 2000). 


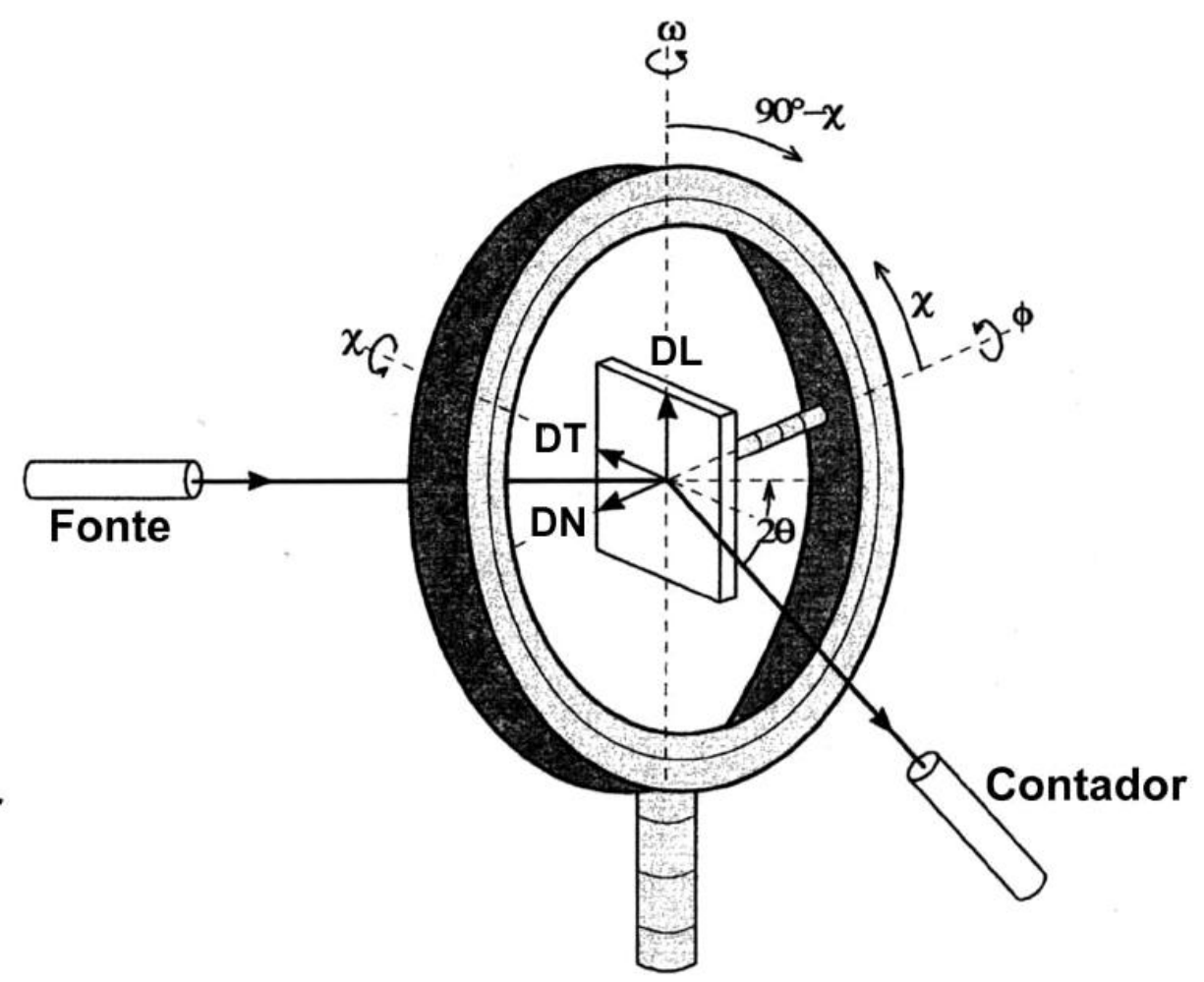

Figura 2.6 - Goniômetro de textura com a geometria de reflexão (RANDLE; ENGLER, 2000).

A composição de uma liga podem influenciar fortemente as texturas de recristalização do material submetido a trabalhos mecânicos (ENGLER; LÜCKE, 1992). Os processos de deformação podem conferir às ligas de alumínio diferentes componentes típicas de textura de laminação. Durante o passe de laminação, o atrito entre os cilindros e a chapa metálica, bem como o conseqüente gradiente de temperatura ao longo de sua espessura, geram estados de deformação heterogêneos (variações geométricas), que conduzem ao aparecimento de diferentes texturas de laminação (plane strain deformation textures) em diferentes camadas da chapa ao longo de sua espessura. Isto leva a mudanças geométricas que influenciam nas diferentes velocidades do fluxo de metal antes e após o ponto neutro (em relação à velocidade de rotação dos cilindros de laminação). Além disso, uma textura de cisalhamento aparece próxima à superfície da chapa, devido às forças de cisalhamento decorrentes do atrito entre os cilindros de laminação e a superfície da chapa metálica (GRAS; MEREDITH; HUNT, 2005; ENGLER; HUH; TOMÉ, 2000; INUOE; TAKASUGI, 2001; SOUZA et al, 2011). 


\section{MATERIAIS E MÉTODOS}

Neste capítulo são descritos o material pesquisado, os métodos experimentais e as principais técnicas de análise microestrutural, bem como de análise da textura cristalográfica.

\subsection{Material}

\subsubsection{Composição química}

As amostras da liga de alumínio AA4006 tiveram sua composição química analisada em um espectrômetro de emissão óptica, marca ARL, modelo 3460 instalado na Companhia Brasileira de Alumínio - CBA. Essas amostras foram preparadas com o lixamento para polimento superficial, desbaste até $1 / 4$ da espessura e desbaste até o centro, com lixa d'água de grão 600 , a fim de verificar se havia variação significativa da composição química ao longo da espessura das chapas.

\subsubsection{Processamento das chapas da liga de alumínio AA4006}

As amostras da chapa obtida pelo processo TRC foram retiradas de uma bobina (com $8 \mathrm{~mm}$ de espessura e $1360 \mathrm{~mm}$ de largura) vazada no equipamento Caster da Companhia Brasileira de Alumínio (CBA). As amostras da chapa obtida pelo processo $D C$ foram retiradas de uma chapa de $8 \mathrm{~mm}$ de espessura e $1360 \mathrm{~mm}$ de largura, a qual foi obtida de uma placa ( $240 \mathrm{~mm}$ de espessura) vazada (via método Direct chill, homogeneizada por 7 horas a $530{ }^{\circ} \mathrm{C}$, e laminada a quente num laminador duo reversível, também na CBA. A temperatura do último passe de laminação foi em torno de $410^{\circ} \mathrm{C}$, na entrada, e em torno de $380{ }^{\circ} \mathrm{C}$, na saída da chapa.

\subsection{Métodos}




\subsubsection{Recozimento inicial}

As amostras da liga de alumínio AA4006 foram recozidas, inicialmente no estado como recebido, em um forno com termopar digital acoplado da marca QUIMIS, modelo Q - 318 D21, instalado no Centro de Ciência e Tecnologia dos Materiais (CCTM) do Instituto de Pesquisas Energéticas e Nucleares (IPEN). A partir de medições de condutividade elétrica nestas amostras das chapas (no estado como recebido) obtidas pelos processos $D C$ e TRC pode-se compreender melhor o efeito da solubilidade sólida em função da temperatura, especialmente do Si no Al. As amostras foram colocadas no forno somente após a temperatura do forno ser estabilizada na temperatura desejada. Elas foram recozidas durante os tempos de 2

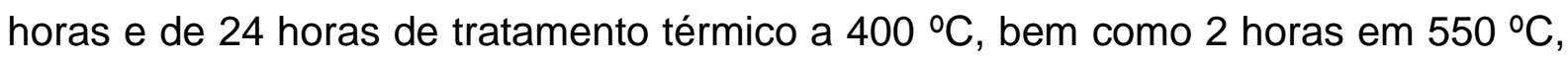
pois solubilidade do Si no alumínio (solubilidade máxima: 1,65\% em massa em 577 ${ }^{\circ} \mathrm{C}$ ) seria alcançada. Foi usado esfriamento rápido (têmpera $\sim 100^{\circ} \mathrm{C} / \mathrm{s}$ ) em água (a $20 \stackrel{\circ}{\circ}$ ) para o 'congelamento' da microestrutura na temperatura desejada para posterior efeito comparativo.

\subsubsection{Laminação a frio}

A laminação a frio foi efetuada na temperatura ambiente, sendo realizada em um laminador instalado no Departamento de Metalurgia e de Materiais (PMT) da Escola Politécnica da Universidade de São Paulo EPUSP com o intuito de se estudar os fenômenos de encruamento, recuperação, recristalização e crescimento de grão, em cada uma das amostras da liga AA4006, com suas respectivas microestruturas e texturas, já que esta liga não é tratável termicamente, isto é, suas propriedades mecânicas somente podem ser melhoradas por trabalho a frio. A direção de laminação escolhida para as amostras foi a direção semelhante à utilizada pelo fabricante. Durante a laminação, foram utilizados três passes de laminação para cada amostra obtida das chapas produzidas pelos processos $D C \mathrm{e}$ TRC com reduções entre $30 \%$ e $40 \%$ em cada passe, a fim de se obter a espessura final desejada (amostra da chapa obtida pelo processo $D C$ : de $8,20 \mathrm{~mm}$ para 2,45 \pm $0,01 \mathrm{~mm}$ e amostra da chapa obtida pelo processo TRC: de $8,10 \mathrm{~mm}$ para 2,42 \pm $0,01 \mathrm{~mm}$ ). Logo, o percentual de deformação nas amostras foi de $70 \%$ de redução em área. 


\subsubsection{Tratamento térmico das amostras laminadas}

As amostras encruadas por laminação a frio foram tratadas termicamente em diferentes temperaturas e tempos, no mesmo forno utilizado anteriormente no tratamento térmico inicial. A fim de estudar os fenômenos de recuperação, encruamento e recristalização, as amostras laminadas com $70 \%$ de redução em espessura foram submetidas a tratamentos isócronos a 150, 250, 300, 350, 400, 450, 500 e $550{ }^{\circ} \mathrm{C}$ por 1 hora, com resfriamento repentino em água. As amostras foram colocadas no forno somente após a temperatura do forno ser estabilizada na temperatura desejada.

\subsection{Técnicas de análise microestrutural}

Para o presente trabalho foram utilizadas diversas técnicas complementares de análise microestrutural e de textura cristalográfica que são apresentadas a seguir:

\subsubsection{Preparação metalográfica}

Para o polimento mecânico, as amostras foram cortadas no sentido transversal e longitudinal, no tamanho aproximado de 8 - $12 \times 12 \mathrm{~mm}$, e preparadas da seguinte forma: em quatro etapas: lixamento com lixa d'água de grão 400, 1000 , 2400 e 4000 polimento grosso com pano MD-Largo de $6 \mu \mathrm{m}$ (Struers) com solução de $6 \mu \mathrm{m}$ (Struers), polimento fino com pano MD-Mol de $3 \mu \mathrm{m}$ (Struers) com solução de $3 \mu \mathrm{m}$ (Struers) e polimento final com pano MD-Nap (Struers) com solução de sílica coloidal OP-S (Struers).

No polimento eletrolítico as amostras foram cortadas no sentido transversal e longitudinal, com o mesmo tamanho anterior, e, lixadas com lixas de grão 600, 800, 1200 e 2400, seguido do polimento eletrolítico. O polimento eletrolítico foi realizado em um aparelho Kristal 620 da ATA GmbH instalado no Laboratório de Metalografia do Departamento de Metalurgia e de Materiais (PMT) da EPUSP. As condições do polimento (TEGART, 1956; DAVIS, 1973) foram: catodo de aço inoxidável, eletrólito: $700 \mathrm{~mL}$ de álcool etílico, $120 \mathrm{~mL}$ de água destilada, $100 \mathrm{~mL}$ de butil glicol, $68 \mathrm{~mL}$ de ácido perclórico (70\%), voltagem de 35 Volts e tempo aproximado de 45 segundos. 
A temperatura do eletrólito foi mantida em baixa temperatura (abaixo de $0{ }^{\circ} \mathrm{C}$ ). Foi utilizada também para o polimento eletrolítico, outra solução composta por $30 \%$ de acido nítrico e $70 \%$ de etanol com diferença de potencial entre 20 e 23 Volts e tempo entre 15 e 30 segundos, com o surgimento de uma corrente que variou de 1,8 a 2,5 A.

Após o polimento mecânico em quatro etapas, as amostras das chapas obtidas pelos processos $D C$ e $T R C$ da liga AA4006 sofreram o ataque químico para a revelação microscópica da morfologia e quantidade dos precipitados. Utilizou-se o seguinte ataque químico: $200 \mathrm{~mL}$ de água destilada e $1 \mathrm{~mL}$ de ácido fluorídrico num tempo de 20 segundos. Após o polimento eletrolítico, as amostras sofreram o ataque eletrolítico de anodização para a revelação da estrutura dos grãos sob luz polarizada (SLÁMOVÁ; OČENÁŠEK; VOORT, 2004). A anodização foi realizada em uma fonte DC POWER SUPPLY - PS3006CD da DAWLER instalada no Laboratório de Metalografia da Companhia Brasileira de Alumínio - CBA. Para este ataque (BARKER, 1950) foram utilizados um catodo de chapa de alumínio, um anodo sendo a própria amostra, um eletrólito de ácido fluobórico 1,8\% em água destilada, e uma voltagem de 20,3 Volts durante um tempo de 360 segundos.

\subsubsection{Microscopia óptica (MO)}

A análise preliminar das microestruturas das amostras das chapas obtidas pelos processos $D C$ e $T R C$ foi feita utilizando a técnica de microscopia óptica, para a observação da morfologia e distribuição dos precipitados. O microscópio utilizado foi o Neophot 30 Carl Zeiss instalado no Laboratório de Metalografia do Departamento de Engenharia Metalúrgica e de Materiais da Escola Politécnica da Universidade de São Paulo (EPUSP).

\subsubsection{Microscopia óptica com luz polarizada}

A microscopia óptica com luz polarizada foi utilizada para a observação da estrutura dos grãos. Para esta análise foi utilizado o microscópio óptico Olympus BX51M e uma câmara fotográfica digital Olympus DP12 acoplada ao microscópio, ambos, instalados no Laboratório de Metalografia da Companhia Brasileira de Alumínio - CBA. As amostras foram preparadas utilizando polimento mecânico 
seguido do ataque eletrolítico (anodização). O ataque visa depositar um filme de $\mathrm{Al}_{2} \mathrm{O}_{3}$ com espessuras características das superfícies de cada grão, pois em materiais policristalinos, a espessura do filme formado depende da orientação cristalográfica do grão que revela os grãos. Quando visto com iluminação polarizada passado através de um analisador, o filme pode girar o plano de polarização considerando a orientação do grão subjacente, produzindo assim várias sombras de preto, cinza ou branco (contraste) que são convertidas em contraste colorido, devido à inserção anterior de uma tintura sensível do polarizador. As amostras foram analisadas nas seções normal, transversal e longitudinal.

\subsubsection{Microscopia eletrônica de varredura (MEV)}

As análises por microscopia eletrônica de varredura foram realizadas em um aparelho modelo XL-30 da Philips, no Laboratório de Microscopia do Departamento de Metalurgia e de Materiais (PMT) da EPUSP. Este equipamento dispõe dos detectores de elétrons secundários (SE) e elétrons retroespalhados (BSE), de analisador de raios $X$ por dispersão de energia (EDS) e de analisador por difração de elétrons retroespalhados (EBSD).

Imagens das microestruturas foram feitas nos modos de elétrons retroespalhados. As amostras foram preparadas por polimento mecânico, sem polimento eletrolítico. A técnica de espectroscopia por dispersão de energia $E D S$, acoplada ao MEV, foi utilizada para a determinação qualitativa das composições químicas dos precipitados presentes nas amostras. As amostras foram preparadas por polimento mecânico, sem polimento eletrolítico.

\subsubsection{Difração de raios X (DRX)}

Para o estudo da macrotextura utilizou-se um goniômetro automático de textura acoplado a um difratômetro Rigaku, modelo DMAX-2000 instalado no Laboratório de Difração de Raios $X$, no Centro de Ciência e Tecnologia dos Materiais (CCTM) do Instituto de Pesquisas Energéticas e Nucleares (IPEN). Utilizou-se radiação $\mathrm{MoKa}_{1}(\lambda=0,7093 \AA)$, passo angular de $5^{\circ}$ e tempo de contagem de 5 segundos. As amostras foram cortadas nas dimensões de $8-10 x$ $15 \mathrm{~mm}$ e preparadas por polimento mecânico e eletrolítico. 
Os planos cristalográficos escolhidos (típicos da estrutura CFC) para levantamento das figuras de pólo foram: (111), (200), (220) e (420) ou (311). A partir dos dados gerados pelas figuras de pólo, foram determinadas as funções de distribuição de orientação (FDO's), utilizando o programa PAT desenvolvido pelo Dr. Nelson Batista de Lima e Eguiberto Galego (LIMA, 1991; GALEGO, 2004).

Análises de textura foram feitas em três posições diferentes (superfície, 1/4 da espessura e centro) no estado como recebido e em duas posições (superfície e centro) nas tiras laminadas das amostras de alumínio de pureza comercial no estado como recebido e após laminação a frio com $70 \%$ de redução em área, a fim de verificar se havia variação significativa da textura cristalográfica, ao longo da espessura.

\subsubsection{Condutividade elétrica}

Utilizou-se essa técnica com a finalidade de estudar a relação entre a condutividade elétrica e os elementos de liga em solução sólida, especialmente do elemento silício na matriz de alumínio. A condutividade elétrica foi medida com auxílio de um condutivímetro digital, modelo DC-9 instalado na Companhia Brasileira de Alumínio - CBA. O condutivímetro é um instrumento para ensaio não destrutivo que mede a condutividade elétrica de metais em \%IACS. A unidade \%IACS (International Annealed Copper Standard) expressa a condutividade dos metais como percentual da condutividade do cobre puro padrão. A precisão dos resultados do condutivímetro é garantida através da calibração do mesmo em um padrão de alumínio em 58,2 \%IACS que fornece valores de condutividade a $20 \stackrel{\circ}{ }$ C. As amostras foram cortadas em aproximadamente $5 \times 5 \mathrm{~cm}$ e possuíam uma superfície limpa e plana, não sendo necessário um polimento. Para o tratamento estatístico de cada amostra da liga de alumínio AA4006 foram realizadas dez medidas. O resultado da condutividade elétrica para cada alumínio é a média das dez medidas realizadas, e para a medida do grau de dispersão dos valores em relação ao valor médio (a média) foi utilizada a função do desvio padrão.

\subsubsection{Microdureza Vickers (HV) e dureza Brinell}

Devido à facilidade e rapidez de realização de medidas de dureza, a dureza 
Vickers é uma das medidas mais utilizadas em análise microestrutural, já que ela cobre toda a faixa de dureza dos metais e também permite a medida em fases individuais, tais como, região recristalizada e região não recristalizada.

A fim de estudar os fenômenos de encruamento, recuperação e recristalização, foi utilizada esta técnica. As medidas de microdureza foram feitas em um microdurômetro Zwick instalado no Departamento de Metalurgia e de Materiais (PMT) da EPUSP. Foi utilizada uma carga de 300 gramas e feito dez medidas por análise, o resultado da dureza para cada alumínio é a média das dez medidas realizadas, e para a medida do grau de dispersão dos valores em relação ao valor médio (a média) foi utilizada a função do desvio padrão. As amostras foram preparadas por polimento mecânico, sem ataque.

Ensaios de dureza Vickers foram feitos, ao longo da espessura, na seção transversal em relação à direção de laminação $D L$, para avaliar se havia variação da dureza ao longo da espessura da chapa obtida pelo processo TRC. As amostras no estado como recebido e tratadas termicamente, nas temperaturas de 150, 250, 300, $350,400,450,500$, e $550 \stackrel{\circ}{C}$ foram ensaiadas no microdurômetro de dureza Vickers, para obtenção da temperatura de recristalização e da curva de amolecimento.

A dureza Brinell é a mais utilizada na engenharia. $O$ ensaio desta medida de dureza, basicamente, consiste em comprimir uma esfera de aço sobre a superfície plana e polida da amostra limpa durante um tempo determinado. Após isto, uma impressão permanente no formato de uma calota esférica produz um diâmetro, o qual é medido com o auxílio de um micrômetro óptico. Utilizando a relação de O’Neil (limite de resistência $\approx 0,40 \mathrm{HB}$ ) os valores aproximados dos limites de resistência das ligas produzidas nos dois processos (TRC e DC) podem ser obtidos a partir dos resultados de dureza Brinell (SOUZA, 1982).

As amostras no estado como recebido e tratadas, por 2 horas e 24 horas a

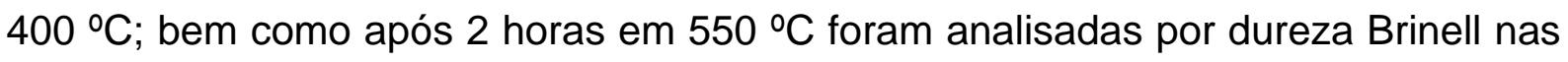
três posições diferentes nas secções normal, longitudinal e transversal, em relação à direção de laminação DL, a fim de verificar se havia variação significativa nas distintas superfícies. Como não houve variação, o tratamento estatístico foi feito sem distinção das posições nas três seções (DT, DN e DL).

\subsubsection{Difração de elétrons retroespalhados EBSD}


A técnica de difração de elétrons retroespalhados (Electron back scatter diffraction) é feita utilizando um aparato (aparelho de microscopia eletrônica de varredura - MEV) de obtenção da figura (padrões) de Kikuchi. Os padrões de Kikuchi são gerados a partir de informações locais da interação da radiação eletrônica do feixe de elétrons na rede cristalina da amostra. A posição da amostra deve estar compreendida entre 70 e $80^{\circ}$ com relação ao feixe de elétrons. As linhas de Kikuchi são captadas por uma tela de fósforo, e, a identificação dessas linhas pode ser feita através da mensuração dos ângulos formados entre elas, bem como comparadas com uma tabela dos ângulos teóricos correspondentes aos planos que difratam a radiação do sistema cristalino analisado (PINTO; LOPES, 2001).

A Figura 3.1 apresenta, de forma esquemática, a realização da técnica de $E B S D$, onde o feixe de elétrons, os padrões de Kikuchi e a amostra na posição (com as direções DN direção normal, DT direção transversal e DL direção de laminação) de análise podem ser vistos.

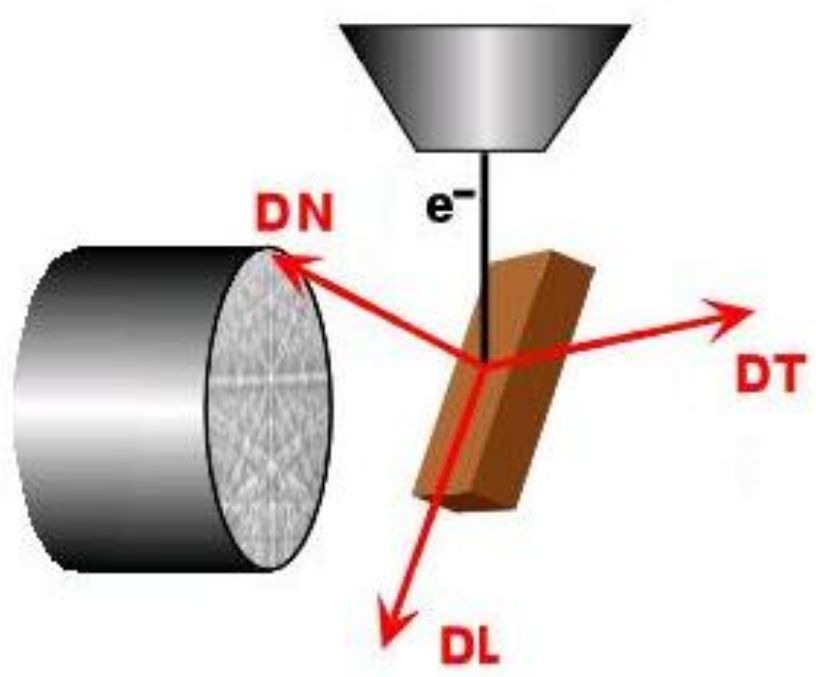

Figura 3.1 - Desenho esquemático da realização da técnica de EBSD.

Duas amostras foram coletadas nas chapas produzidas pelos processos TRC e $D C$ e, posteriormente, laminadas a frio com $70 \%$ de redução em área, seguidas de recozimento a $400 \stackrel{\circ}{\circ}$ (tratamento para a recristalização), por uma hora, e, submetidas à análise de EBSD no MEV. 


\section{RESULTADOS E DISCUSSÕES}

Os resultados e discussões serão divididos e apresentados conforme os seguintes itens:

- caracterização das microestruturas e das texturas cristalográficas das amostras das chapas obtidas pelos processos TRC e DC da liga de alumínio AA4006, amostras no estado como recebido e amostras sob recozimento a $400 \stackrel{\circ}{\circ}$ durante 2 e 24 horas, bem como a $550 \stackrel{\circ}{C}$ por 2 horas, para estudar a dureza e a condutividade elétrica (no estado como recebido);

- laminação a frio (encruamento) das amostras, com $70 \%$ de redução em área, seguida de tratamentos térmicos isócronos (150, 250, 300, 350, 400, 450, 500 e 550 @C por 1 hora), com posterior determinação das curvas de amolecimento para os materiais obtidos pelos métodos $T R C$ e $D C$; microanálise e extração de precipitados presentes na matriz de alumínio; determinação da temperatura de recristalização; obtenção da condutividade elétrica das amostras submetidas a tratamentos térmicos isócronos, para análise de precipitação e dissolução de soluto em solução sólida na matriz, com o auxílio das curvas TTT de precipitação-recristalização;

- determinação da textura (macrotextura) das amostras laminadas a frio, bem como das amostras recozidas a $400{ }^{\circ} \mathrm{C}$ por uma hora (recristalizadas), utilizando-se raios X; e obtenção da microtextura e mesotextura nestas amostras recozidas (recristalizadas), utilizando-se EBSD.

\subsection{Microestruturas das amostras das chapas obtidas pelos processos $D C$ e $T R C$ no estado como recebido}

\subsubsection{Composição química}

A Tabela 4.1 apresenta as composições químicas, em porcentagem em massa, das amostras das chapas obtidas pelos processos TRC e $D C$, utilizadas neste trabalho, da liga de alumínio AA4006. As análises foram realizadas em três posições, ao longo da espessura (superfície, a $1 / 4$ da espessura e no centro), utilizando-se a técnica de espectrometria de emissão óptica (num espectrômetro da 
marca ARL, modelo 3460, instalado na Companhia Brasileira de Alumínio CBA).

Tabela 4.1 - Composições químicas (\% em massa) ao longo da espessura (8 mm) de amostras das chapas obtidas pelos processos $D C$ e TRC da liga AA4006.

\begin{tabular}{cccccccccc}
\hline & Posição & $\mathrm{Si}$ & $\mathrm{Fe}$ & $\mathrm{Cu}$ & $\mathrm{Mn}$ & $\mathrm{Mg}$ & $\mathrm{Ni}$ & $\mathrm{Zn}$ & $\mathrm{Ti}$ \\
\hline \multirow{2}{*}{ DC } & superfície & 1,080 & 0,640 & 0,012 & 0,012 & 0,002 & 0,004 & 0,008 & 0,010 \\
& $1 / 4$ & 1,078 & 0,650 & 0,012 & 0,012 & 0,002 & 0,004 & 0,007 & 0,012 \\
& centro & 1,072 & 0,643 & 0,012 & 0,012 & 0,002 & 0,004 & 0,007 & 0,013 \\
\hline \multirow{3}{*}{ TRC } & superfície & 1,175 & 0,748 & 0,005 & 0,017 & 0,002 & 0,004 & 0,008 & 0,011 \\
& $1 / 4$ & 1,150 & 0,727 & 0,005 & 0,017 & 0,002 & 0,003 & 0,007 & 0,012 \\
& centro & 1,167 & 0,742 & 0,006 & 0,017 & 0,002 & 0,004 & 0,007 & 0,012 \\
\hline
\end{tabular}

Apesar da grande diferença na forma de distribuição dos precipitados ao longo da espessura da tira metálica produzida pelo método $T R C$, como pode ser visto adiante na análise microestrutural, não foi constatada uma variação significativa na quantidade dos elementos constituintes em amostras das ligas (TRC e $D C$ ). Na Tabela 1 pode ser visto que na amostra da liga TRC há maior presença dos solutos $\mathrm{Si}$ e Fe na amostra da liga $D C$.

\subsubsection{Microestruturas das chapas}

As Figuras 4.1 e 4.2, apresentam uma visão geral das microestruturas vistas com o auxílio da microscopia óptica de luz polarizada, com as distribuições granulométricas nas respectivas amostras das chapas obtidas pelos processos $D C \mathrm{e}$ $T R C$, nas secções normal $\mathrm{DN}$, longitudinal $\mathrm{DL}$ e transversal $\mathrm{DT}$, em relação à direção de laminação $D L$, enquanto que, nas Figuras 4.3 e 4.4, estão apresentadas as micrografias, que revelam as distribuições de precipitados (nas mesmas amostras das Figuras 4.1 e 4.2), obtidas por microscopia eletrônica de varredura. 


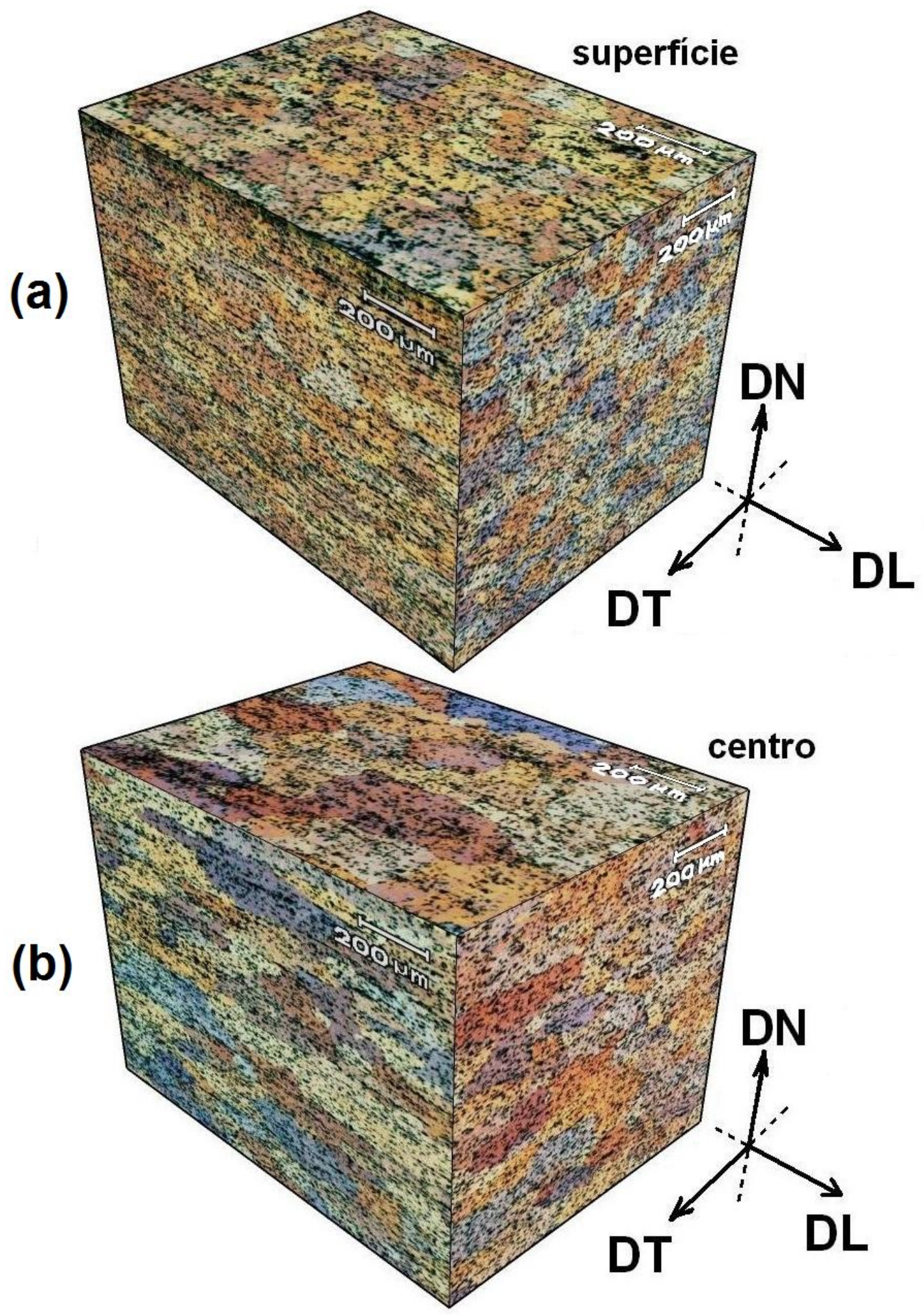

Figura 4.1 - Microestruturas obtidas por MO nas regiões (a) próxima à superfície e (b) central da chapa da liga AA4006 (no estado como recebido) obtida pelo processo $D C$. 


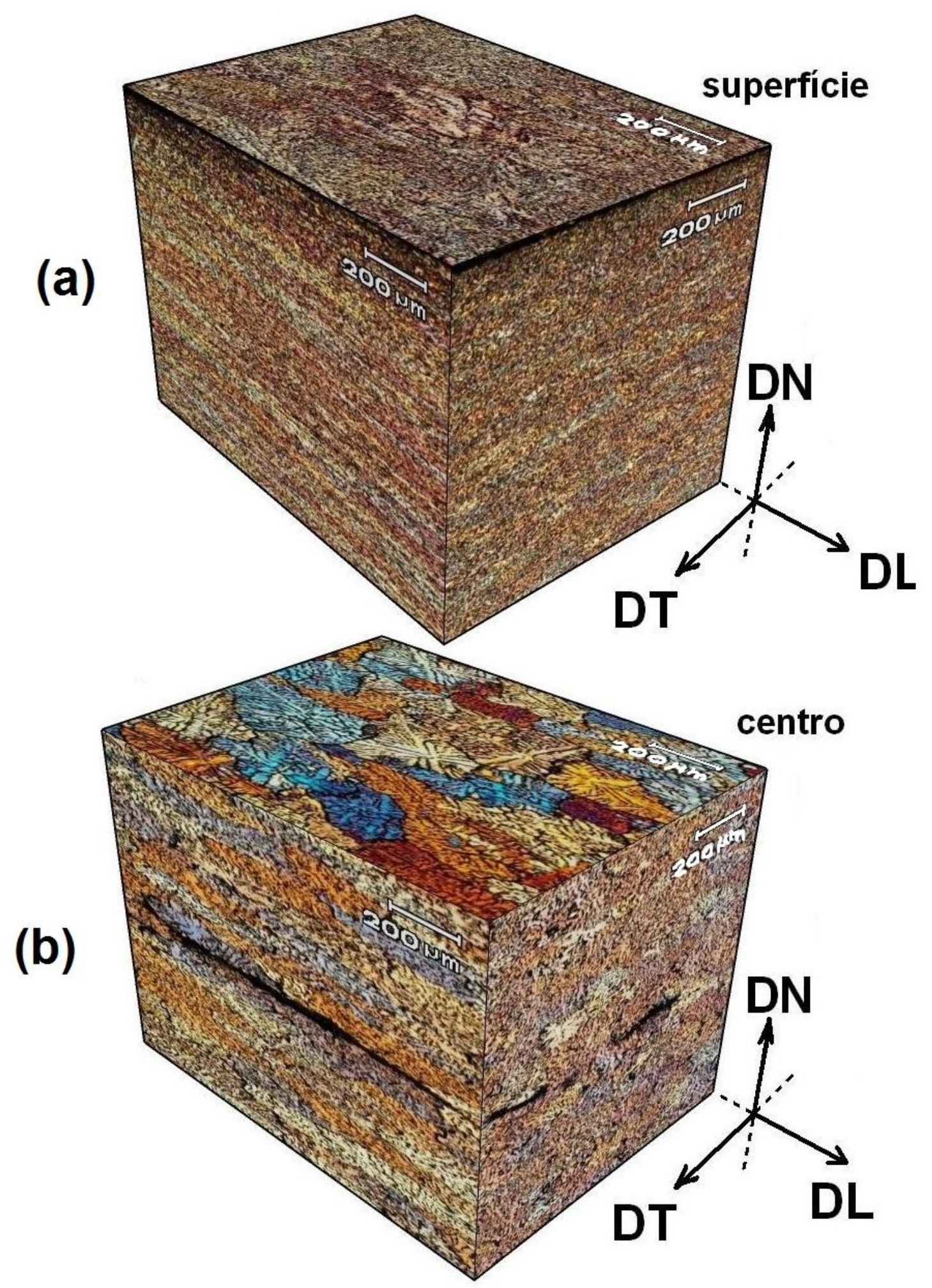

Figura 4.2 - Microestruturas obtidas por MO nas regiões (a) próxima à superfície e (b) central da chapa da liga AA4006 (no estado como recebido) obtida pelo processo TRC. 


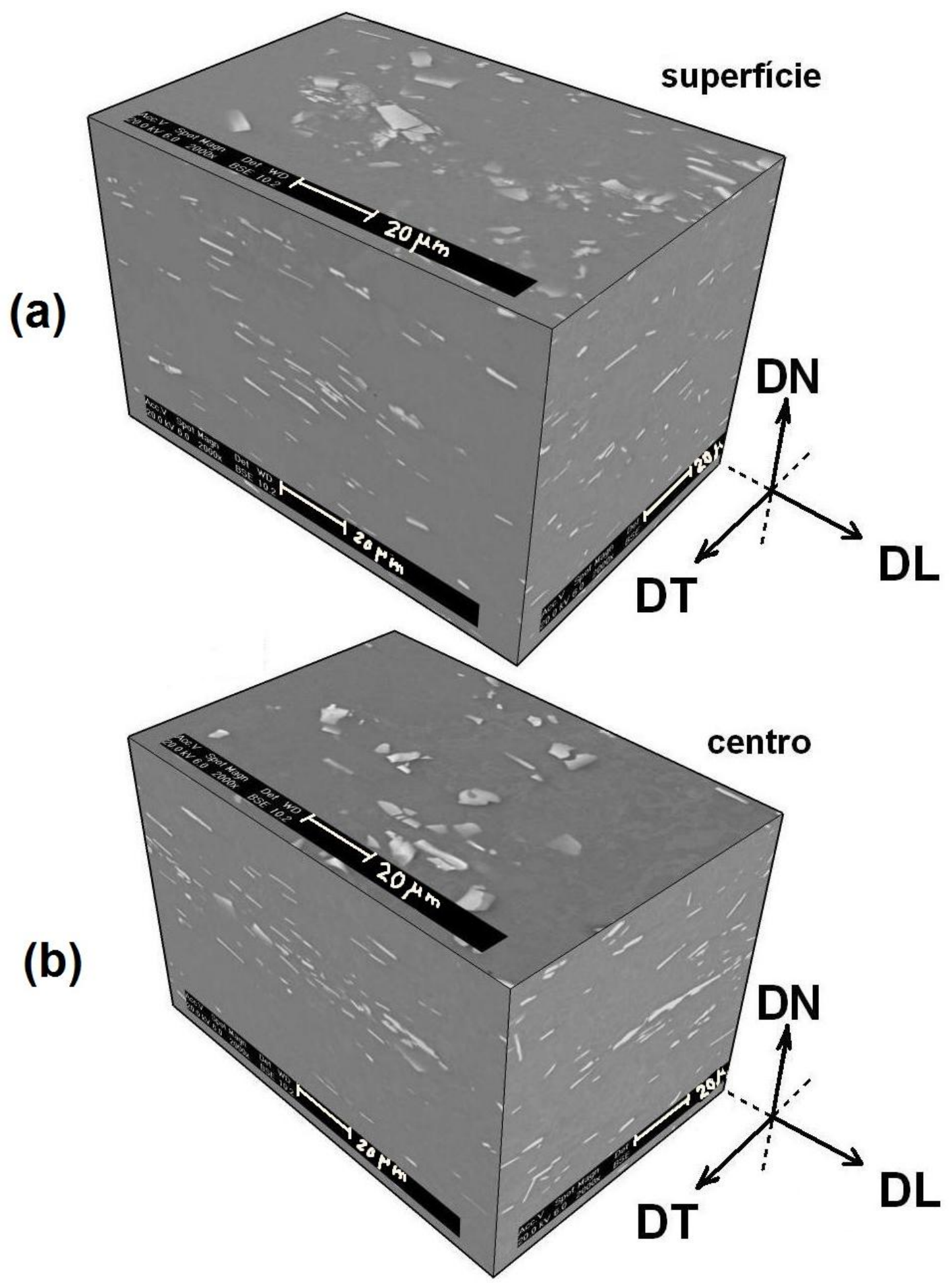

Figura 4.3 - Micrografias obtidas por MEV mostrando a distribuição dos precipitados nas regiões (a) próxima à superfície e (b) central da chapa da liga AA4006 (no estado como recebido) obtida pelo processo $D C$. 


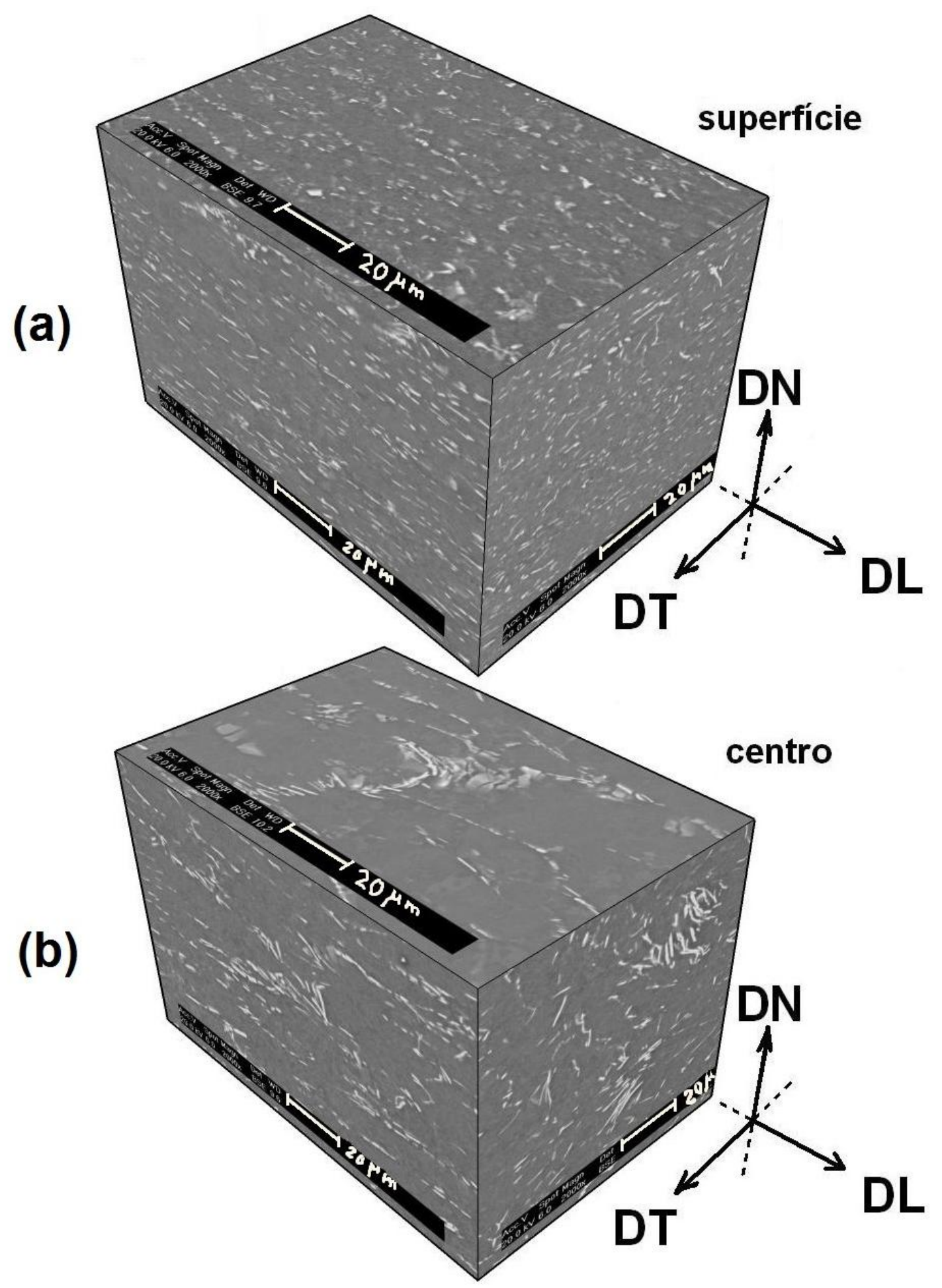

Figura 4.4 - Micrografias obtidas por MEV mostrando a distribuição dos precipitados nas regiões (a) próxima à superfície e (b) central da chapa da liga AA4006 (no estado como recebido) obtida pelo processo $T R C$.

A amostra da chapa produzida pelo processo DC apresentou uma microestrutura formada por grãos maiores (não dendríticos) do que os grãos da 
amostra obtida por lingotamento contínuo (processo TRC), bem como uma relativa homogeneidade, ao longo da espessura, como pode ser visto na Figura 4.1. O gradiente de temperatura ao longo da espessura da chapa obtida pelo processo $D C$, submetida às diferentes etapas de processamento envolvidos no método $D C$, é diferente do gradiente de temperatura na chapa obtida pelo processo TRC (vide Figura 4.7), pois, as diferenças microestruturais entre os dois processos são devidas às etapas de homogeneização além da laminação a quente que são aplicadas no método $D C$.

$\mathrm{Na}$ Figura $4.2 \mathrm{a}$ e $4.2 \mathrm{~b}$, uma microestrutura constituída por grãos alongados pode ser vista na amostra da chapa obtida pelo processo TRC, sendo que nas proximidades da superfície da chapa os grãos são bem mais alongados do que na região central. Nas Figuras 4.3 e 4.4, as distribuições dos precipitados nas chapas obtidas pelos processos DC e TRC podem ser comparadas. Na Figura 4.5 as distribuições dos precipitados no centro das chapas produzidas pelos dois processos podem ser vistas, de forma mais ampla. Nestas imagens, na 'chapa $D C$ ', nota-se a presença de precipitados alongados e orientados na direção de laminação, conforme ilustram as fotomicrografias nas Figuras 4.3a e 4.3b. Na microestrutura próxima à superfície, na amostra da chapa obtida pelo processo TRC (Figura 4.4a), pode ser visto uma dispersão de precipitados mais finos, devido à alta supersaturação do soluto, pode ser visto também a distribuição de grandes quantidades de soluto nas bordas dos grãos dendríticos (Figura 4.5b).

As diferenças de morfologia e distribuição de precipitados, observadas nas amostras da chapa obtida pelo processo TRC, ao longo da espessura, ocorrem, devido à refrigeração com água dos cilindros de laminação, acarretando em alta taxa de resfriamento na superfície, seguida da deformação, logo após a rápida solidificação, como detectado em outras ligas de alumínio (FERNANDES; PADILHA, 2008; MARTINS; PADILHA, 2006). Nas regiões mais distantes da superfície da chapa obtida pelo processo TRC, onde a taxa de resfriamento é mais lenta, a microestrutura é formada por grãos de solidificação dendrítica, como pode ser visto na Figura 4.4b. Dessa forma, a rejeição ou expulsão de soluto, durante o crescimento das dendritas, pode conduzir à microssegregação no centro da chapa que prejudica a utilização do material na forma de folhas, já que esta linha central de segregação de soluto pode causar pequenas perfurações em folhas durante a laminação (ROBERT; SANDERS, 2012; JACOBS, 1999). 
$\mathrm{Na}$ região central da liga AA4006 TRC foi constatado o aparecimento de colônias de precipitados com uma microestrutura lamelar e a incidência de colônias lamelares eutéticas, situadas nas regiões inter-dendríticas (Figuras 4.2b e 4.4b). Próximo à superfície, há a surgimento de precipitados intermetálicos menores, conforme ilustrado na Figura 4.4a. Já nas fotomicrografias da Figura 4.6a, pode ser vista a microestrutura numa região que abrange toda a espessura da chapa obtida pelo processo $T R C$, e a região central lamelar, bem como a forma dos precipitados nesta região que pode ser vista em micrografia ampliada obtida por microscopia óptica MO com ataque químico utilizando HF (Figura 4.6b). 


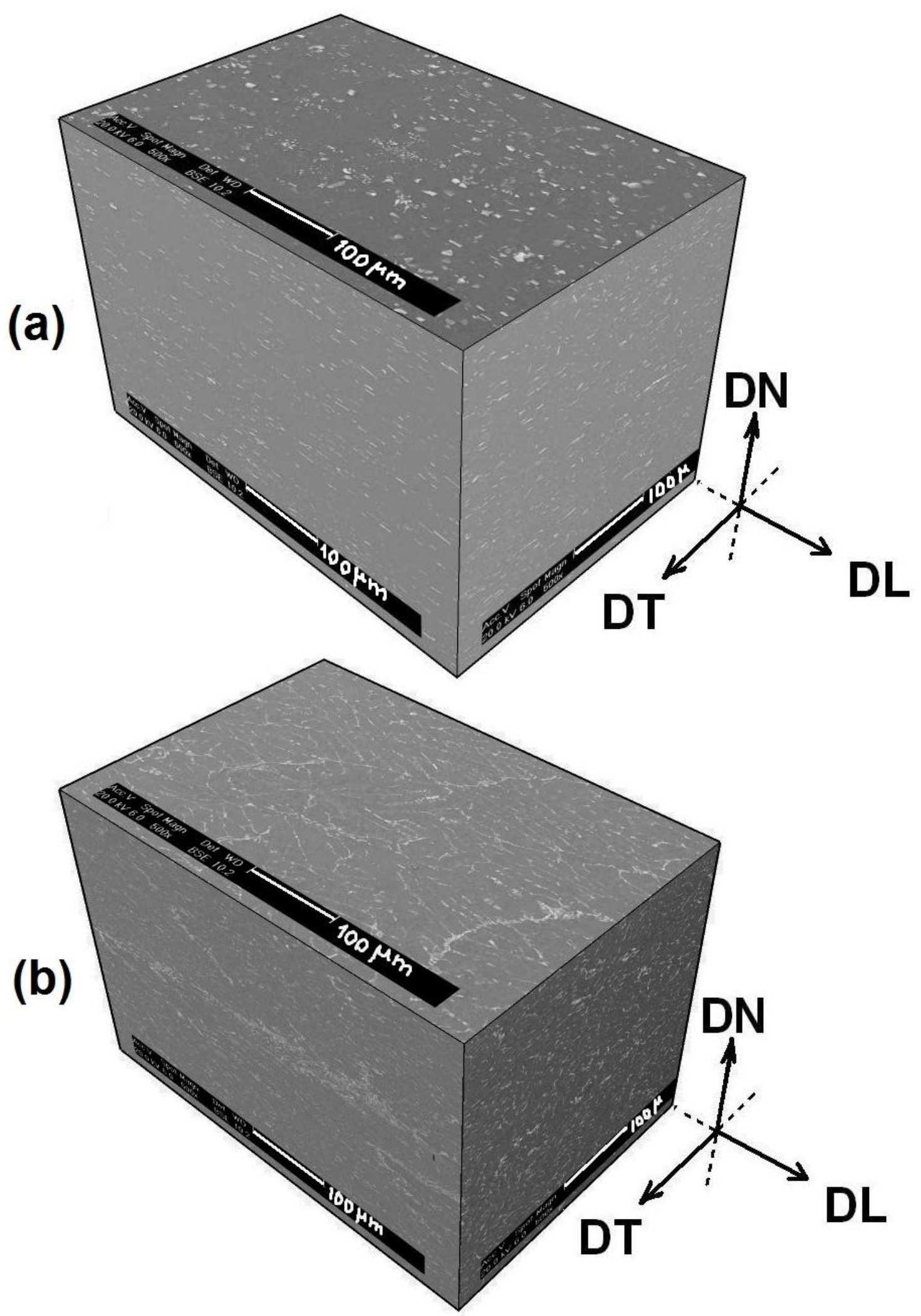

Figura 4.5 - Micrografias obtidas por MEV mostrando a distribuição dos precipitados na região central das chapas da liga AA4006 (no estado como recebido) obtidas pelos processos (a) $D C$ (b) $T R C$. 


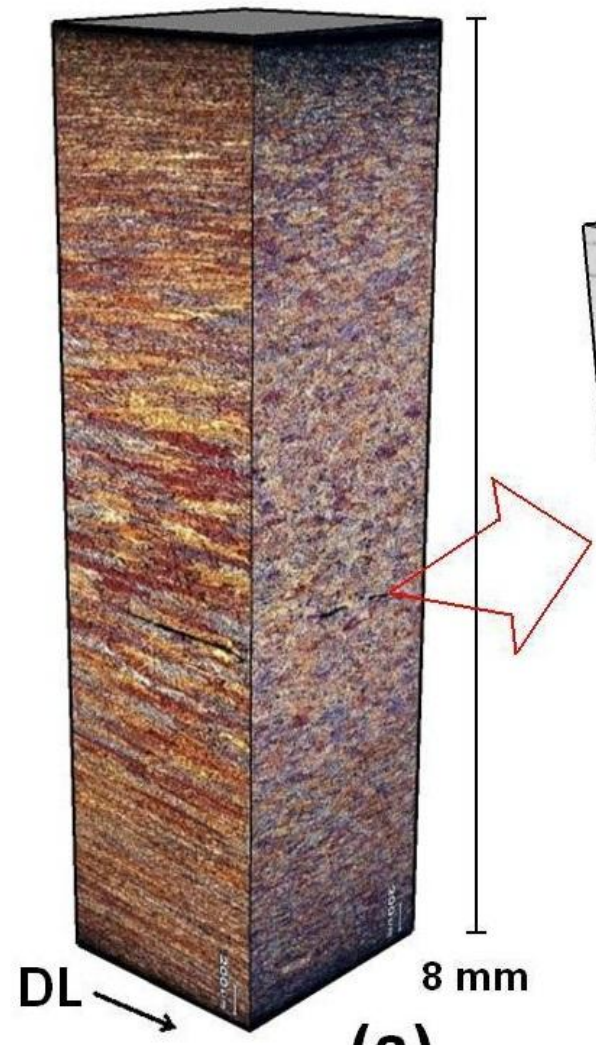

(a)

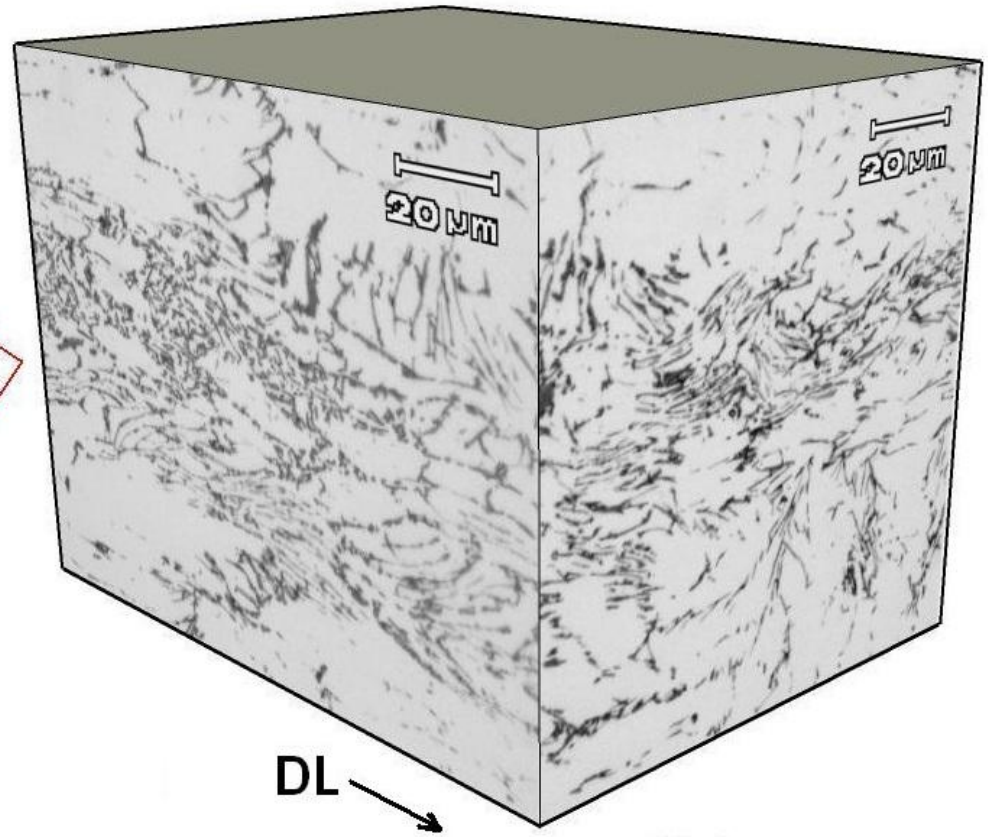

(b)

Figura 4.6 - (a) Microestrutura obtida por MO da espessura (amostra anodizada com solução contendo $\mathrm{HBF}_{4}$ ) e (b) micrografia com maior aumento obtida por $\mathrm{MO}$ (ataque químico em solução contendo HF) mostrando a distribuição lamelar dos precipitados na região central da chapa da liga AA4006 (no estado como recebido) obtida pelo processo TRC.

Durante a solidificação da liga, as mudanças na taxa de resfriamento local podem influenciar o tamanho das dendritas. A Figura 4.7 apresenta o tamanho da estrutura dendrítica (tamanho médio de dendritas e/ou de braços dendríticos encontrados numa seção planar na amostra com polimento metalográfico) em função da taxa de resfriamento de ligas de alumínio, onde pode ser visto que o tamanho da estrutura dendrítica torna-se menor, gradativamente, à medida que a taxa de resfriamento é aumentada (SPEAR; GARDNER, 1963). 


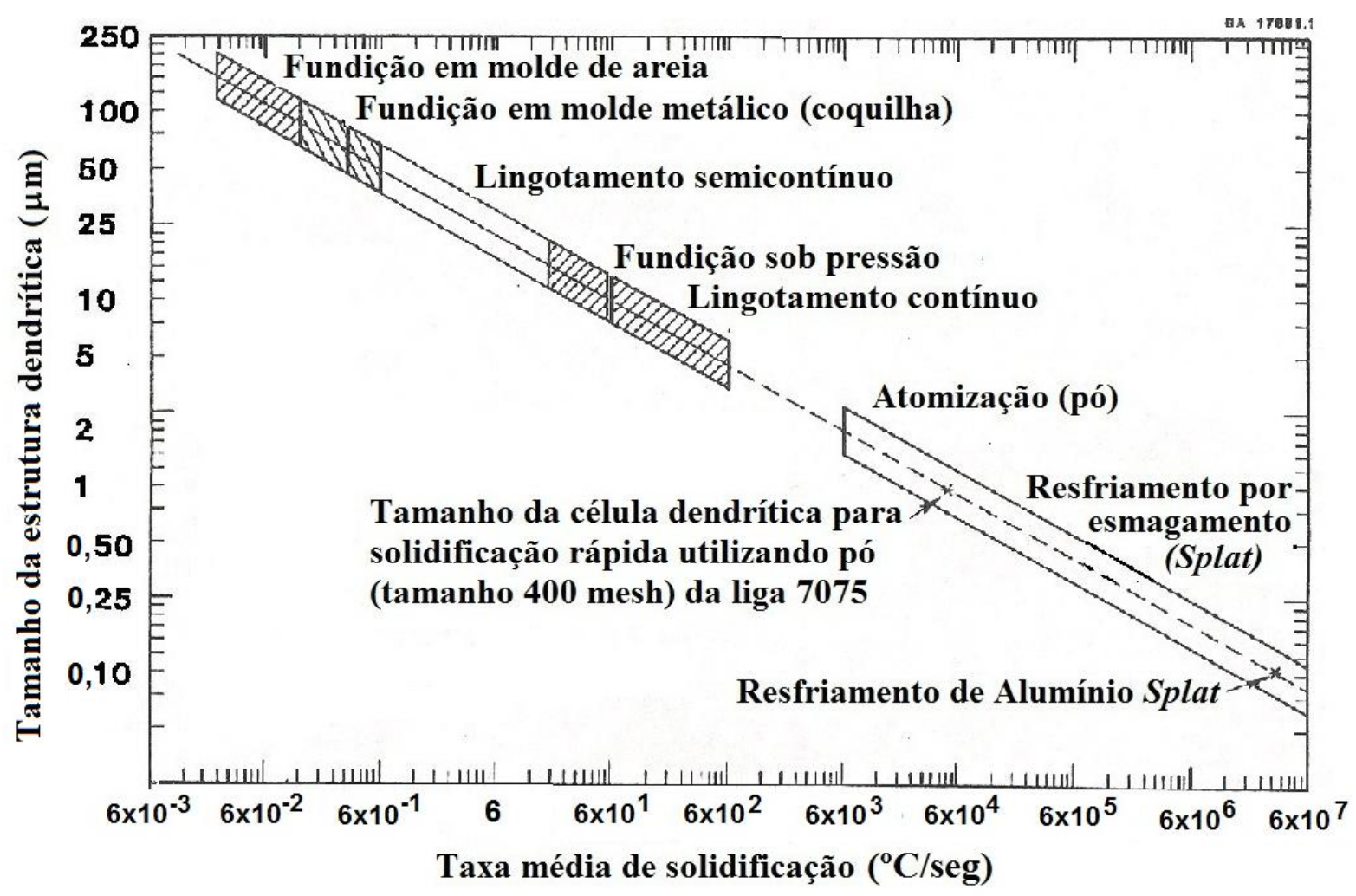

Figura 4.7 - Relação entre o tamanho da estrutura dendrítica e a taxa de solidificação para ligas de alumínio (SPEAR; GARDNER, 1963).

Os diagramas de fases ternário Al-Fe-Si e binário Al-Si podem ser utilizados para estudar, controlar e localizar diferentes fases sólidas com a combinação de seus respectivos elementos em equilíbrio termodinâmico. Neste contexto, as ligas com composições próximas de $100 \%$ de alumínio, e localizadas na região da borda do $\mathrm{Al}$, podem apresentar diferentes fases em suas microestruturas. Com o objetivo de justificar esses comportamentos microestruturais, na Figura 4.8, foram dispostos dois diagramas de fases ternários Al-Fe-Si e um binário Al-Si. A Figura 4.8c apresenta o diagrama ternário Al-Fe-Si com a quantidade de Fe em massa fixa em $0,7 \%$, quantidade similar às das chapas da liga AA4006 pesquisadas neste trabalho (MONDOLFO, 1976). A região marcada com um contorno na cor vermelha nesta figura sugere uma possível região com as composições da liga AA4006, onde as fases intermetálicas citadas podem ocorrer, caso o resfriamento permitisse que 0 equilíbrio termodinâmico no sistema ternário fosse atingido.

A Figura 4.8 (a) apresenta o diagrama binário Al-Si onde pode ser visto que em altas temperaturas ( $570 \stackrel{\circ}{\circ}$ com \% Si menor que 1,65$)$ o Si está dissolvido na matriz de Al (JACOBS, 1999). A solubilidade do Fe no alumínio é muito menor 
(solubilidade máxima: 0,052\% em massa em $655^{\circ} \mathrm{C}$ ) do que a solubilidade do Si no alumínio (solubilidade máxima: 1,65\% em massa em $577 \stackrel{\circ}{\circ}$ e 0,05\% a $250 \stackrel{\circ}{\circ}$ ) (PADILHA; PLAUT, 2003). A reação eutética, líquido produzindo $\mathrm{Al}+\mathrm{Fe}_{4} \mathrm{Al}_{13}$ (ou $\mathrm{Al}_{3} \mathrm{Fe}$ ), ocorre à medida que a solidificação avança, em seguida, as duas reações peritéticas ternárias, líquido $+\mathrm{Fe}_{4} \mathrm{Al}_{13}$ transformando em $\mathrm{Al}+\mathrm{Fe}_{2} \mathrm{SiAl}_{8}$ (fase $\alpha$ ) e líquido $+\mathrm{Fe}_{2} \mathrm{SiAl}_{8}$ transformando em $\mathrm{Al}+\mathrm{FeSiAl}_{5}$ (fase $\beta$ ), bem como uma eutética ternária, líquido mudando para $\mathrm{Al}+\mathrm{FeSiAl}_{5}$, ocorrem em ligas do sistema $\mathrm{Al}-\mathrm{Fe}-\mathrm{Si}$ no canto rico em Al (Figura 4.8 b) (ALLEN et al, 1998).
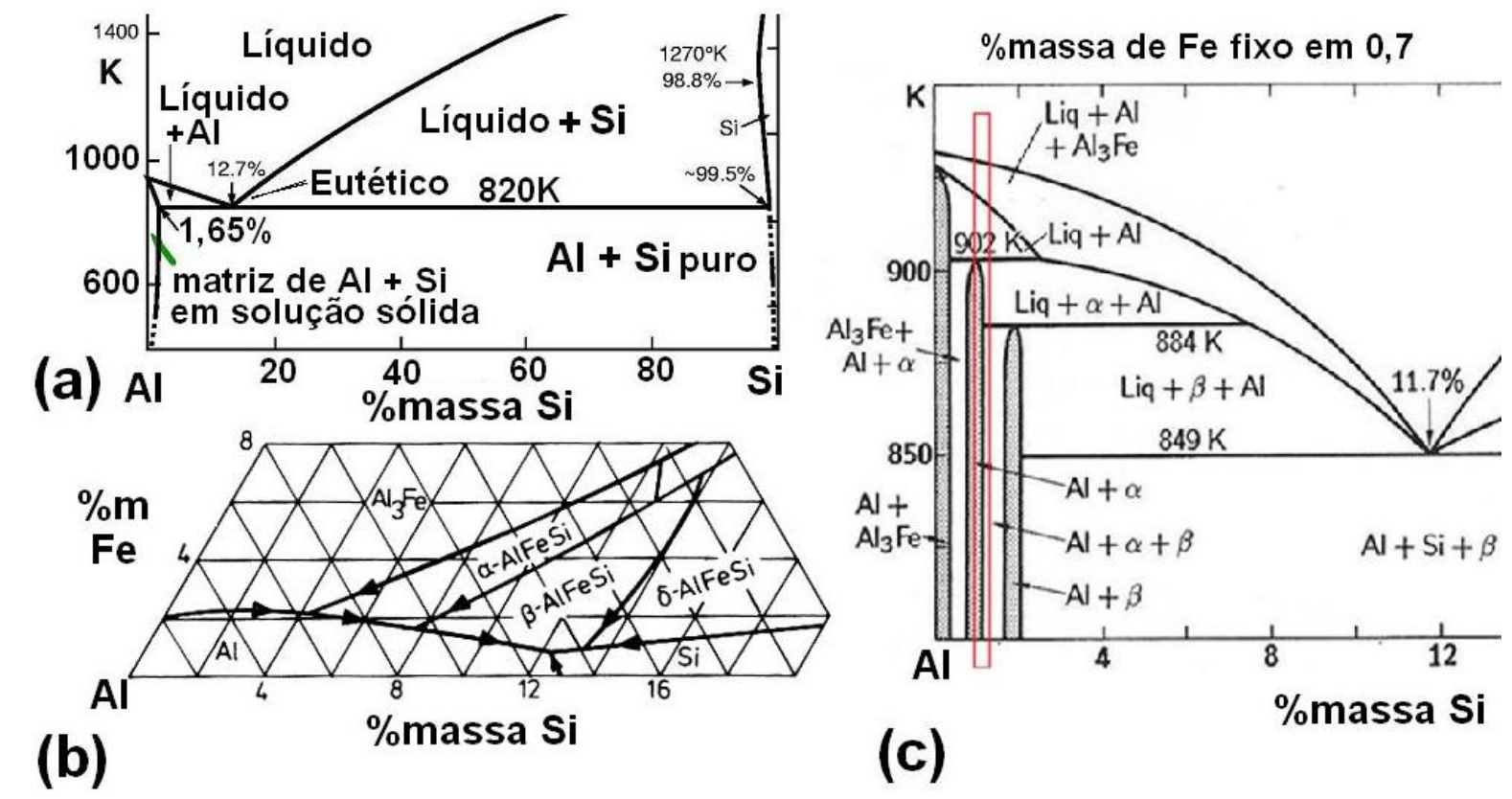

Figura 4.8 - (a) Diagrama binário de equilíbrio Al-Si (JACOBS, 1999), (b) superfície liquidus do diagrama ternário Al-Fe-Si no canto rico em Al (ALLEN et al, 1998) e (c) diagrama ternário $\mathrm{Al}-\mathrm{Fe}-\mathrm{Si}$ no canto rico em $\mathrm{Al}$ com a quantidade de Fe fixa em 0,7 \% em massa (GHOSH, 1992; MONDOLFO, 1976).

Estas fases de equilíbrio também podem surgir em condições onde a solidificação acontece fora do equilíbrio, como no caso de chapas obtidas em processos industriais, e o líquido se torna rico em Si, devido à distribuição do Si no líquido interdendrítico. Dessa forma, a tendência de formação das fases ternárias é grande. Além disso, distintas variantes estruturais destas fases $\alpha\left(\mathrm{Fe}_{2} \mathrm{SiAl}_{8}\right)$ e $\beta$ $\left(\mathrm{FeSiAl}_{5}\right.$ ) são observadas em 'ligas $D C$ ', assim como precipitados do tipo $\mathrm{Fe}_{4} \mathrm{Al}_{13}$ (ou $\mathrm{Al}_{3} \mathrm{Fe}$ ), como reportado por alguns autores (ALLEN et al, 1998; GHOSH, 1992; 
MONDOLFO, 1976). A Tabela 4.2 apresenta as principais fases sólidas vistas nos diagramas ternários $\mathrm{Al}-\mathrm{Fe}-\mathrm{Si}$, bem como as faixas de temperatura onde elas podem ser encontradas e seus respectivos parâmetros de rede, no intuito de mostrar que diferentes fases podem surgir em ligas de Al-Fe-Si .

Tabela 4.2 - Fases sólidas, suas faixas de temperatura e parâmetros de rede (GHOSH, 1992).

\begin{tabular}{|c|c|c|}
\hline Fases & Faixa de temperatura $\left({ }^{\circ} \mathrm{C}\right)$ & Parâmetros de rede (pm) \\
\hline (Al) & $\leq 660,5$ & $a=404,88$ \\
\hline$\alpha$ ou $(\alpha \mathrm{Fe})$ ou $(\alpha \delta \mathrm{Fe})$ & $\leq 1538$ & $a=286,65$ \\
\hline$(\mathrm{Si})$ & $\leq 1414$ & $a=543,09$ \\
\hline$\alpha_{1}$ ou $\mathrm{Fe}_{3} \mathrm{Al}$ & $\leq 552$ & $a=579,23$ \\
\hline$\alpha_{2}$ ou FeAl & $\leq 1310$ & $a=290,90$ \\
\hline$\varepsilon$ ou $\mathrm{Fe}_{2} \mathrm{Al}_{3}$ & $1215-1092$ & - \\
\hline$\zeta$ ou $\mathrm{FeAl}_{2}$ & $\leq 1154$ & $\begin{array}{l}a=487,80 b=646,10 c=880,00 \\
\alpha=91,75^{\circ} \beta=73,27^{\circ} \gamma=96,89^{\circ}\end{array}$ \\
\hline$\rho$ ou FeSi & $\leq 1410$ & $a=448,91$ \\
\hline$\eta$ ou $\mathrm{Fe}_{2} \mathrm{Al}_{5}$ & $\leq 1171$ & $a=767,50 b=640,30 c=420,30$ \\
\hline$\Theta$ ou $\mathrm{FeAl}_{3}$ & $\leq 1152$ & $\begin{array}{c}a=1548,90 b=808,30 c=1247,60 \\
\beta=107,72^{\circ}\end{array}$ \\
\hline к ou $\mathrm{Fe}_{5} \mathrm{Si}_{3}$ & $1060-825$ & $a=675,52 c=471,74$ \\
\hline$(\mathrm{\gamma Fe})$ ou $(\alpha \mathrm{Fe})$ & $\leq 1538$ & $a=286,65$ \\
\hline wh ou $\mathrm{Fe}_{2} \mathrm{Si}(\mathrm{h})$ & $1212-1040$ & $a=405,20 c=508,55$ \\
\hline $\mathrm{T}_{1}$ ou $\mathrm{Fe}_{3} \mathrm{Al}_{3} \mathrm{Si}_{2}$ & - & - \\
\hline $\mathrm{T}_{2}$ ou $\mathrm{Fe}_{2} \mathrm{Al}_{5} \mathrm{Si}_{2}$ & - & $a=1603,23$ \\
\hline $\mathrm{T}_{3}$ ou $\mathrm{Fe}_{5} \mathrm{Al}_{9} \mathrm{Si}_{5}$ & - & $a=768,00 b=1530,00 c=1600,00$ \\
\hline $\mathrm{T}_{4}$ ou $\mathrm{FeAl}_{3} \mathrm{Si}_{3}$ & - & $a=612,23 c=948,91$ \\
\hline $\mathrm{T}_{5}$ ou $\mathrm{Fe}_{2} \mathrm{Al}_{7,4} \mathrm{Si}$ & - & $a=1239,40 c=2621,00$ \\
\hline $\mathrm{T}_{6}$ ou $\mathrm{Fe}_{2} \mathrm{Al}_{9} \mathrm{Si}_{2}$ & - & $\begin{array}{c}a=612,23 b=612,23 c=4148,36 \\
\beta=91,00^{\circ}\end{array}$ \\
\hline $\mathrm{T}_{7}$ ou $\mathrm{Fe}_{22} \mathrm{Al}_{40} \mathrm{Si}_{38}$ & - & - \\
\hline $\mathrm{T}_{8}$ ou $\mathrm{Fe}_{32} \mathrm{Al}_{38} \mathrm{Si}_{30}$ & - & - \\
\hline $\mathrm{T}_{9}$ ou $\mathrm{Fe}_{36} \mathrm{Al}_{36} \mathrm{Si}_{28}$ & - & - \\
\hline $\mathrm{T}_{10}$ ou $\mathrm{Fe}_{5} \mathrm{Al}_{12} \mathrm{Si}_{3}$ & - & $a=752,60 c=763,20$ \\
\hline
\end{tabular}

As Figuras 4.9 e 4.10 apresentam imagens captadas utilizando elétrons 
retroespalhados na obtenção das micrografias por microscopia eletrônica de varredura (MEV) em ambas as chapas produzidas pelos dois processos TRC e $D C$, bem como os espectros de dispersão de energia (energy-dispersive spectroscopy; EDS) nas regiões indicadas nas micrografias para estas chapas no estado como recebido. As amostras para a obtenção destas imagens foram polidas mecanicamente. $\mathrm{Na}$ Figura $4.9 \mathrm{~b}$, podem ser vistos também, os valores característicos das energias de Ka e de K $\beta$ para os elementos Al, Si e Fe (CULLITY; STOCK, 2001; GOLDSTEIN et al, 1992).

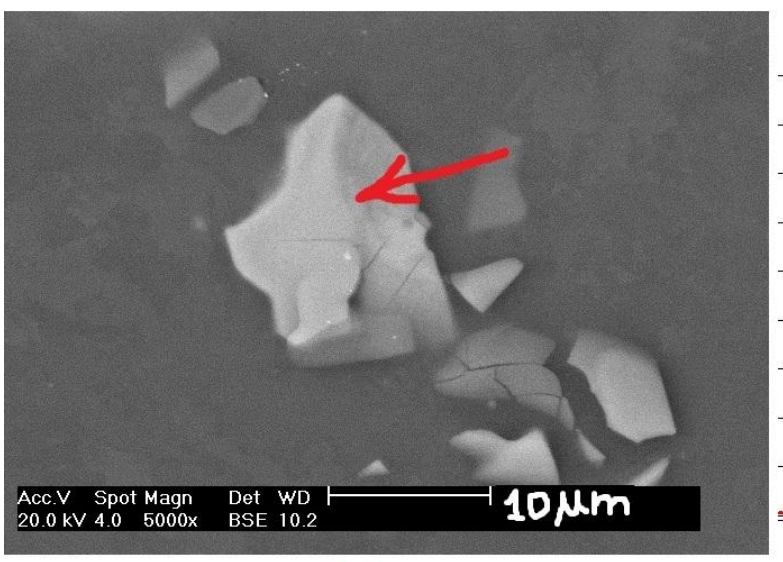

(a)

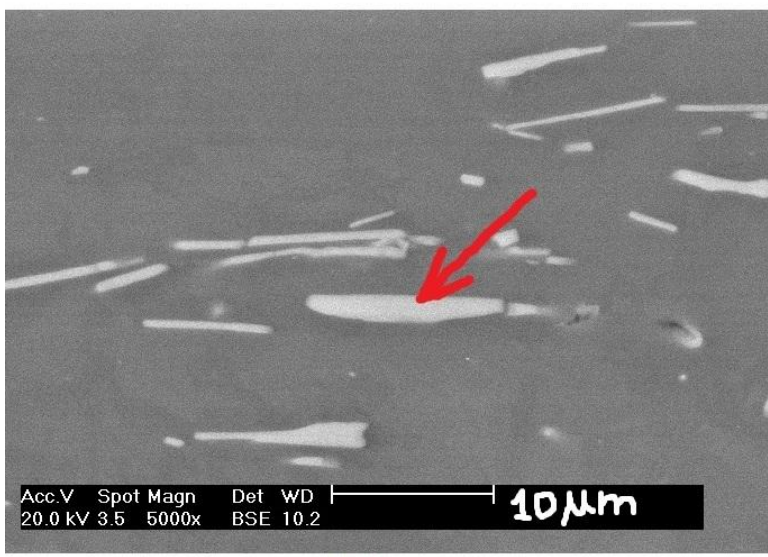

(c)

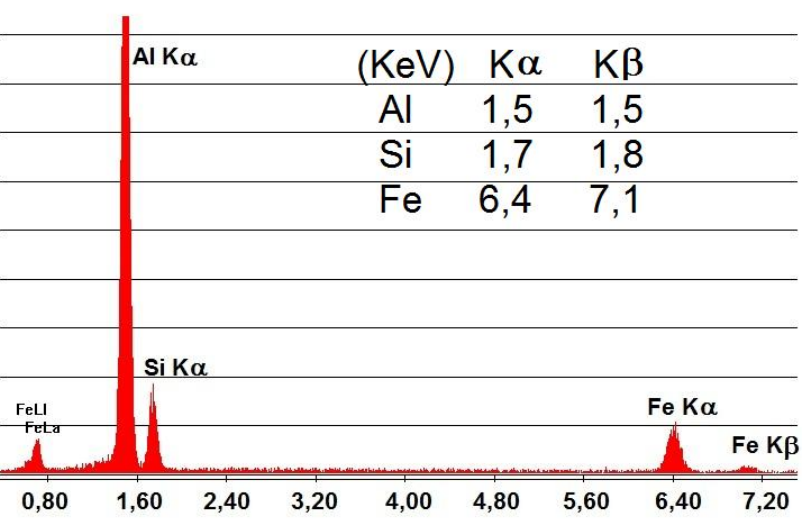

(b)

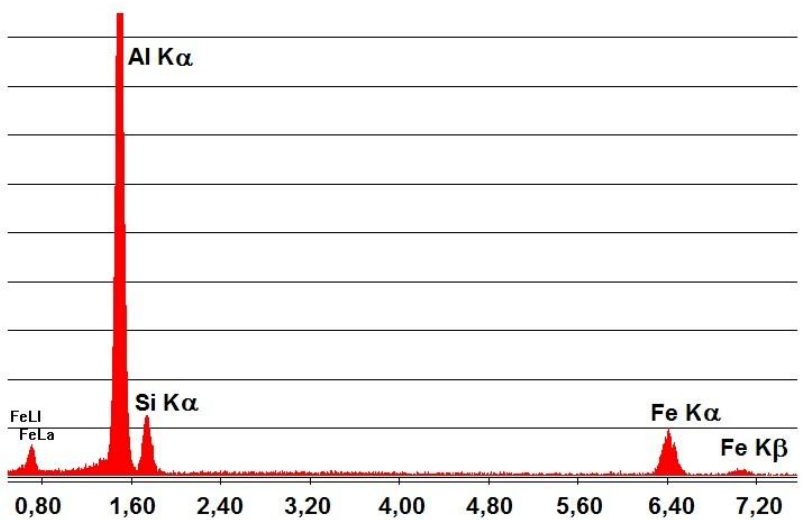

(d)

Figura 4.9 - Precipitados encontrados em amostras da região central da chapa da liga AA4006 (no estado como recebido) obtida pelo processo $D C$, (a) seção normal e (c) seção transversal. (b) e (d) Espectros de dispersão de energia (EDS) destes precipitados indicados pelas setas nas micrografias.

A análise qualitativa de elementos numa amostra é uma importante ferramenta para a microanálise química, já que elementos em quantidades bem 
pequenas, na composição média da liga, podem ser detectados, quando concentrados em microrregiões ou micro-partículas. Nas Figuras 4.9 e 4.10 pode ser visto que precipitados ou fases ternárias podem estar presentes na liga AA4006. A análise aqui feita com EDS é uma análise qualitativa, assim, durante a interação do feixe eletrônico com a amostra para determinação da composição química do precipitado, o elemento base da matriz (Al) ou até mesmo algum elemento (soluto) dissolvido na matriz pode ser detectado juntamente, ou seja, eles podem ser detectados e contados como parte do precipitado. Logo, não há relevância, neste caso, em quantificar as intensidades de energia nos espectros de EDS ou quantidades de cada elemento ( $\mathrm{Al}, \mathrm{Fe}$, e $\mathrm{Si}$ ) nestas amostras.

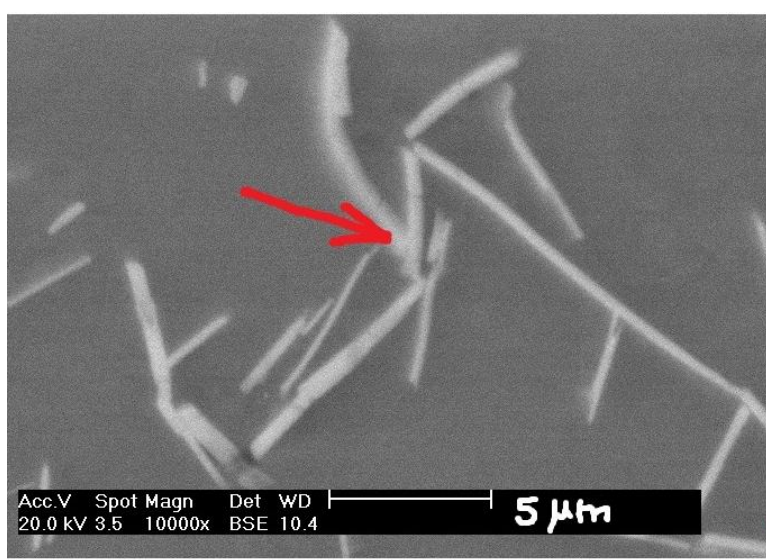

(a)

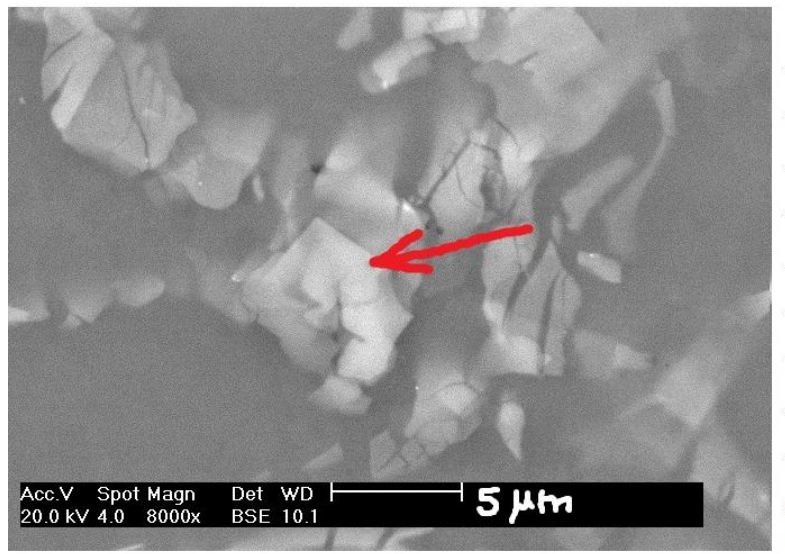

(c)

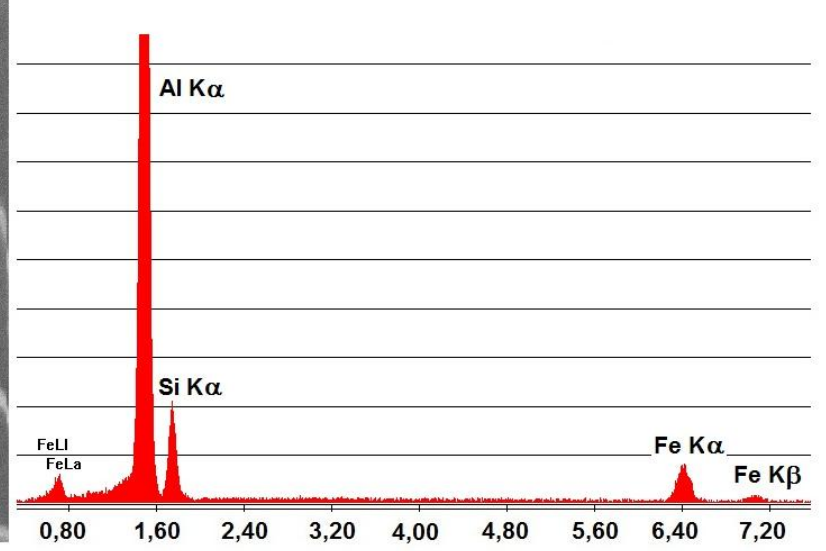

(b)

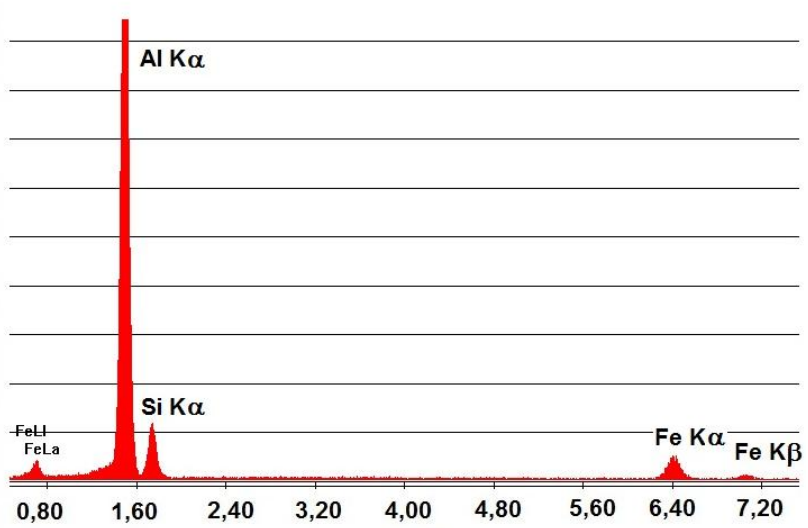

(d)

Figura 4.10 - Aglomerados de precipitados na seção transversal (a) encontrados em amostras da região central da chapa da liga AA4006 (no estado como recebido) obtida pelo processo TRC e na seção normal (c). Espectros de dispersão de energia (EDS) (b) e (d) destes precipitados indicados pelas setas nas micrografias. 


\subsubsection{Condutividade elétrica, dureza e tamanho de grão}

Com base na análise anterior, sobre os diagramas de fases, assim como do comportamento dos seus elementos e de suas fases constituintes convém estudar e compreender melhor o efeito da solubilidade sólida em função da temperatura, especialmente do Si no Al. Assim, foram realizadas medições de condutividade elétrica nas amostras das chapas obtidas pelos processos $D C$ e TRC. Na Tabela 4.3 as condutividades elétricas em \%IACS das amostras da liga AA4006 são apresentadas em quatro condições: no estado como recebido; após 2 horas e 24 horas de tratamento térmico a $400^{\circ} \mathrm{C}$; bem como após 2 horas em $550{ }^{\circ} \mathrm{C}$. As amostras tratadas termicamente, durante duas horas a $550 \stackrel{\circ}{ } \mathrm{C}$, apresentaram uma condutividade elétrica, consideravelmente, inferior às demais, indicando que parte do Si foi dissolvido na matriz de Al, já que a condutividade elétrica é muito sensível aos átomos de soluto (neste caso, Si), em solução sólida, como detectado em outras ligas de AI (OLIVEIRA; PADILHA, 2009) e conforme visto na Figura 4.8a.

Tabela 4.3 - Condutividades elétricas de amostras das chapas obtidas pelos processos $D C$ e $T R C$ da liga AA4006 em diferentes temperaturas e tempos.

\begin{tabular}{lllll}
\hline (\% IACS) & Como recebido & 2 horas $400^{\circ} \mathrm{C}$ & 24 horas $400^{\circ} \mathrm{C}$ & 2 horas $550{ }^{\circ} \mathrm{C}$ \\
\hline$D C$ & $54,0 \pm 0,1$ & $58,0 \pm 0,1$ & $58,9 \pm 0,1$ & $52,2 \pm 0,1$ \\
$T R C$ & $55,1 \pm 0,1$ & $57,9 \pm 0,1$ & $57,7 \pm 0,1$ & $51,6 \pm 0,1$ \\
\hline
\end{tabular}

Além da difusão no volume, durante o recozimento de ligas de alumínio brutas de fundição a migração de contornos de alto ângulo também pode induzir a redistribuição de soluto na matriz por difusão ao longo do contorno de grão (FALLEIROS, 1972). A resistividade elétrica de ligas de alumínio do sistema Al-Fe-Si depende fortemente da contribuição do soluto em solução sólida e em menor grau da densidade de defeitos cristalinos introduzidos na deformação plástica (OLIVEIRA; PADILHA, 2009). Por esta razão as amostras tratadas a $400 \stackrel{\circ}{\circ}$, com tempos suficientes (2 e 24 horas, nessa caso) para a difusão de soluto , apresentaram uma condutividade elétrica maior que as demais. Esse comportamento sugere que após o recozimento a $400{ }^{\circ} \mathrm{C}$ ocorreu saída de átomos de soluto (Si) (antes em solução sólida nas ligas $T R C$ e $D C$ supersaturas) da matriz de Al durante a precipitação. Por outro lado, na temperatura de $550^{\circ} \mathrm{C}$, provavelmente, ocorreu aumento de soluto em 
solução sólida, devido à dissolução parcial de precipitados, causando diminuição da condutividade elétrica.

A Tabela 4.4 apresenta as medidas de dureza Brinnell para as mesmas amostras. Estas medidas foram realizadas nas diferentes faces ou superfícies (longitudinal, transversal e normal) e não apresentaram variações significativas ao longo da espessura nem em faces discriminadas das chapas obtidas pelos dois processos. As diferenças observadas na dureza destas amostras, no estado como recebido, podem ser explicadas com base nos mecanismos de endurecimento. $O$ forte encruamento presente na chapa produzida pelo processo TRC resulta numa dureza maior que na chapa produzida pelo método $D C$, devido à maior densidade de discordâncias presentes na chapa TRC, como observado e discutido em trabalho anterior (MARTINS; CARVALHO; PADILHA, 2009).

Tabela 4.4 - Medidas de dureza Brinnell de amostras das chapas obtidas pelos processos $D C$ e $T R C$ da liga AA4006 em diferentes temperaturas e tempos.

\begin{tabular}{lllll}
\hline (HB) & Como recebido & 2 horas $400^{\circ} \mathrm{C}$ & 24 horas $400^{\circ} \mathrm{C}$ & 2 horas $550^{\circ} \mathrm{C}$ \\
\hline$D C$ & $30 \pm 1$ & $26 \pm 2$ & $28 \pm 2$ & $32 \pm 1$ \\
$T R C$ & $40 \pm 1$ & $35 \pm 1$ & $32 \pm 1$ & $33 \pm 2$ \\
\hline
\end{tabular}

Durante o tratamento térmico, os processos de recuperação e recristalização ocorrem no material e as discordâncias podem ser aniquiladas, rearranjadas para configurações de menor energia e absorvidas por contornos de alto ângulo em migração (PADILHA; SICILIANO, 2005). Estes fenômenos mudam a dureza de um dado metal e podem causar o amolecimento deste. Por esta razão, nas amostras tratadas termicamente da chapa produzida pelo processo TRC, devido aos processos de recuperação e recristalização, houve uma diminuição da dureza, ou

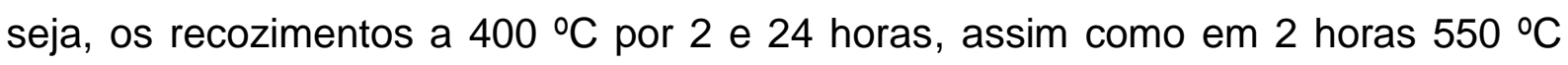
causaram a eliminação de boa parte das discordâncias introduzidas pela deformação plástica, durante o processo de produção $T R C$, proporcionando uma dureza ligeiramente menor nas amostras recozidas do que na amostra no estado como recebido. Nas amostras da chapa produzida pelo processo $D C$, não houve variação significativa entre as amostras no estado como recebido e recozidas, já que esta chapa havia sido laminada a quente acima da temperatura de recristalização durante o processo industrial $D C$. Nas amostras tratadas a $550{ }^{\circ} \mathrm{C}$, durante duas 
horas, pode ser observado que o efeito da solubilidade do Si pouco afeta a dureza do material. Vale lembrar que a liga AA4006 (não tratável termicamente) não é endurecível por precipitação coerente, apesar de alguns autores (YEUNG; LEE, 1998) reportarem, de forma errônea, que esta liga é tratável termicamente.

Na Tabela 4.5 são apresentados os valores do diâmetro médio dos grãos dos alumínios, no estado como recebido. Os valores foram obtidos medindo-se o número de intersecções de uma linha teste com os contornos de grão nas micrografias das amostras na direção transversal, pois na direção normal e na longitudinal a contagem dos tamanhos de grão se torna inviável, como pode ser visto na "amostra $T R C^{\prime}$, Figura 4.2a.

Tabela 4.5 - Diâmetro médio dos grãos na direção transversal de amostras das chapas obtidas pelos processos DC e TRC da liga AA4006 no estado como recebido.

\begin{tabular}{lll}
\hline Amostras & $\begin{array}{l}\text { Diâmetro médio }(\mu \mathrm{m}) \\
\text { Superfície / Centro }\end{array}$ & $\begin{array}{l}\text { Tamanho ASTM } \\
\text { Superfície / Centro }\end{array}$ \\
\hline$D C$ & $74 \pm 7 / 233 \pm 41$ & $4,1 \pm 0,4 / 0,8 \pm 0,1$ \\
$T R C$ & $41 \pm 6 / 156 \pm 24$ & $5,9 \pm 0,9 / 2,0 \pm 0,3$ \\
\hline
\end{tabular}

A liga produzida por $T R C$ apresentou granulação mais fina que a liga produzida por DC. As amostras produzidas pelos dois processos apresentaram tamanhos de grão relativamente grandes, principalmente na região central, pois as mesmas ainda não foram submetidas à laminação a frio, a qual reduz muito o diâmetro médio de grão, já que as amostras se encontram no estado como recebido.

\subsection{Texturas cristalográficas das chapas no estado como recebido}

\subsubsection{Textura nas amostras das chapas obtidas pelos processos DC e TRC}

Uma descrição mais completa e quantitativa da textura cristalográfica pode ser obtida com o auxílio da função distribuição de orientação dos grãos (FDO ou $O D F$ - Orientation Distribution Function). Estas funções especificam a freqüência de ocorrência de determinadas orientações em um espaço tridimensional. Este espaço 
é definido (vide Figura 4.11) por três ângulos de Euler. $\varphi_{1}$ (ou $\left.\phi_{1}\right), \Phi, \varphi_{2}$ (ou $\left.\phi_{2}\right)$.
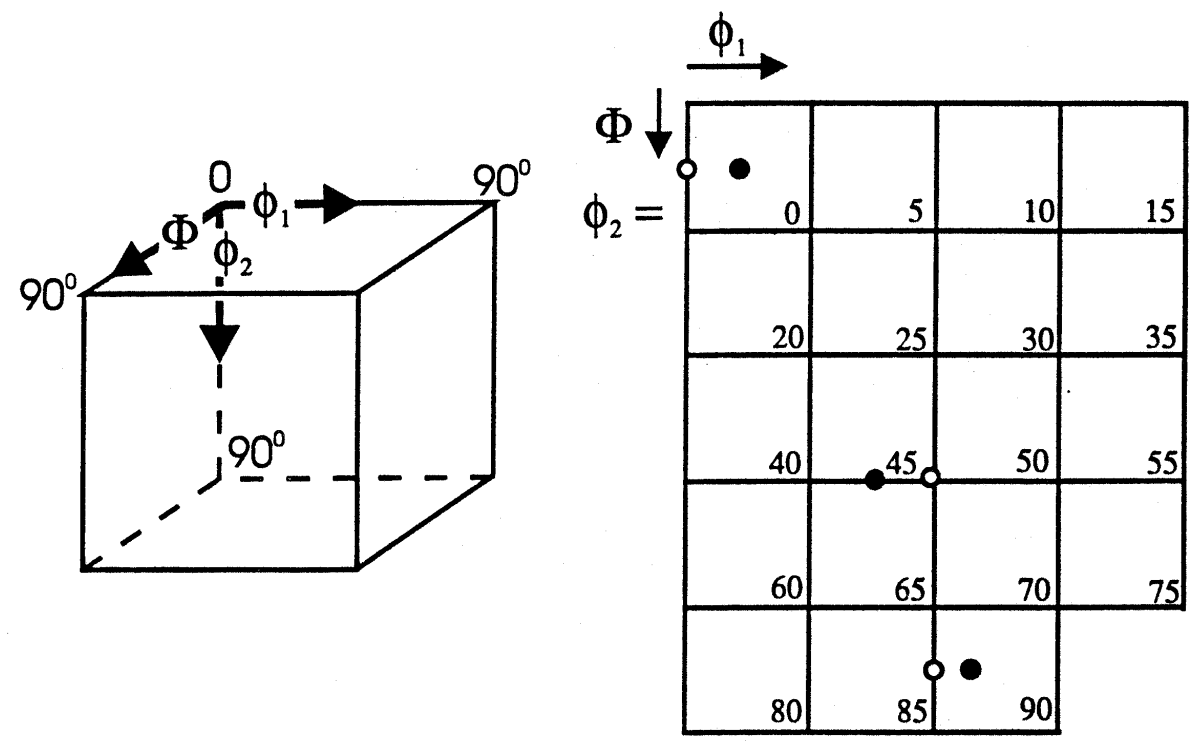

Figura 4.11 - Seções da FDO mostrando a localização das orientações $\{011\}<100>$ (cujo símbolo na figura é ${ }^{\circ}$ ) e $\{011\}<112>$ (cujo símbolo na figura é •) comumente encontradas em metais com estrutura cúbica. Para melhores detalhes ver referência (ALUMATTER, 2010).

A textura da chapa pode ser analisada através da observação da orientação dos grãos em um determinado plano cristalográfico $\{\mathrm{hkl}\}$, aproximadamente, paralelo ao plano da superfície da chapa e com uma determinada direção <uvw> do plano $\{h k l\}$, aproximadamente, paralelo à direção de laminação (LÖW, 2000). Na Figura 4.12 pode ser constatado que a superfície da chapa TRC da liga AA4006 apresentou as componentes de textura $\{001\}<100>$ cubo, $\{001\}<110>$ cubo rodado e $\{001\}<310>$ com intensidades de 9,97; 8,51 e 7,06, respectivamente. A textura cubo rodado (vista como textura de cisalhamento) de maior intensidade é uma componente que ocorre na superfície de chapas deformadas de ligas de alumínio. Ela é causada pelo atrito com o cilindro de laminação durante o processo de lingotamento contínuo TRC, como discutido por alguns autores (BENUM; ENGLER; NES, 1994; GRAS; MEREDITH; HUNT, 2005; SOUZA et al, 2011), enquanto que, a textura cubo aparece comumente em ligas de alumínio laminadas e recozidas (ENGLER; LÜCKE, 1992). 


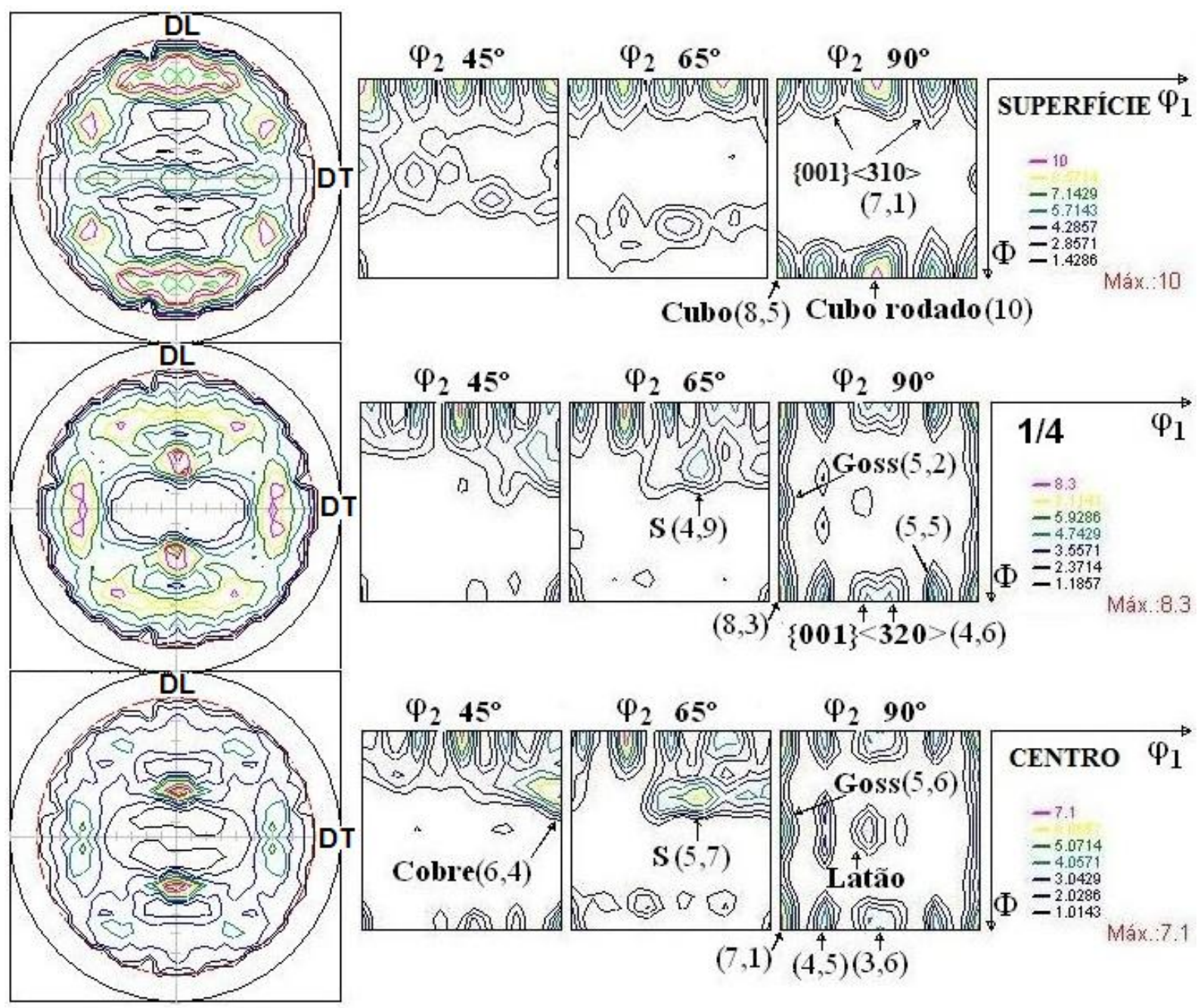

Figura 4.12 - Figuras de pólo (111) e FDO's para a superfície, 1/4 e centro da chapa produzida pelo processo TRC da liga AA4006.

Na Figura 4.12 também pode ser observado que na região de $1 / 4$ da espessura da chapa produzida pelo processo TRC as componentes de textura encontradas foram $\{001\}<100>$ cubo, com máxima intensidade $(8,3)$, bem como $\{011\}<100>$ Goss e $\{123\}<634>S$ com intensidades intermediárias 5,2 e 4,9 , respectivamente. A componente $\{001\}<310>$ aparece com uma intensidade 5,5. Ao invés da textura $\{001\}<110>$ cubo rodado, vista na superfície da chapa, a componente $\{001\}<320>$ foi aqui encontrada com intensidade 4,6. Além disso, são vistas as componentes Goss (intensidade intermediária), $\{112\}<111>$ cobre e $\{011\}<211>$ latão (com fracas intensidades). Já na região central da chapa, há o aparecimento das componentes vistas na superfície e em $1 / 4$ da espessura, porém a componente cubo rodado aparece com a intensidade bem inferior, e as componentes de textura de deformação planar Goss, latão, S e cobre aparecem com maiores intensidades, 
quando comparadas com suas intensidades relativas na região de 1/4 da espessura. Além disso, pode ser observado que a componente cubo rodado (textura de cisalhamento), em $1 / 4$ da espessura e no centro, aparece com intensidade bem mais fraca que na superfície, enquanto que, a componente de textura de deformação, cubo, aparece com maior intensidade nestas regiões ( $1 / 4$ da espessura e centro). Consequentemente, a fibra $\beta$ (componente cobre, $S$ e latão) aparece com intensidade considerável no centro da chapa produzida pelo processo TRC.

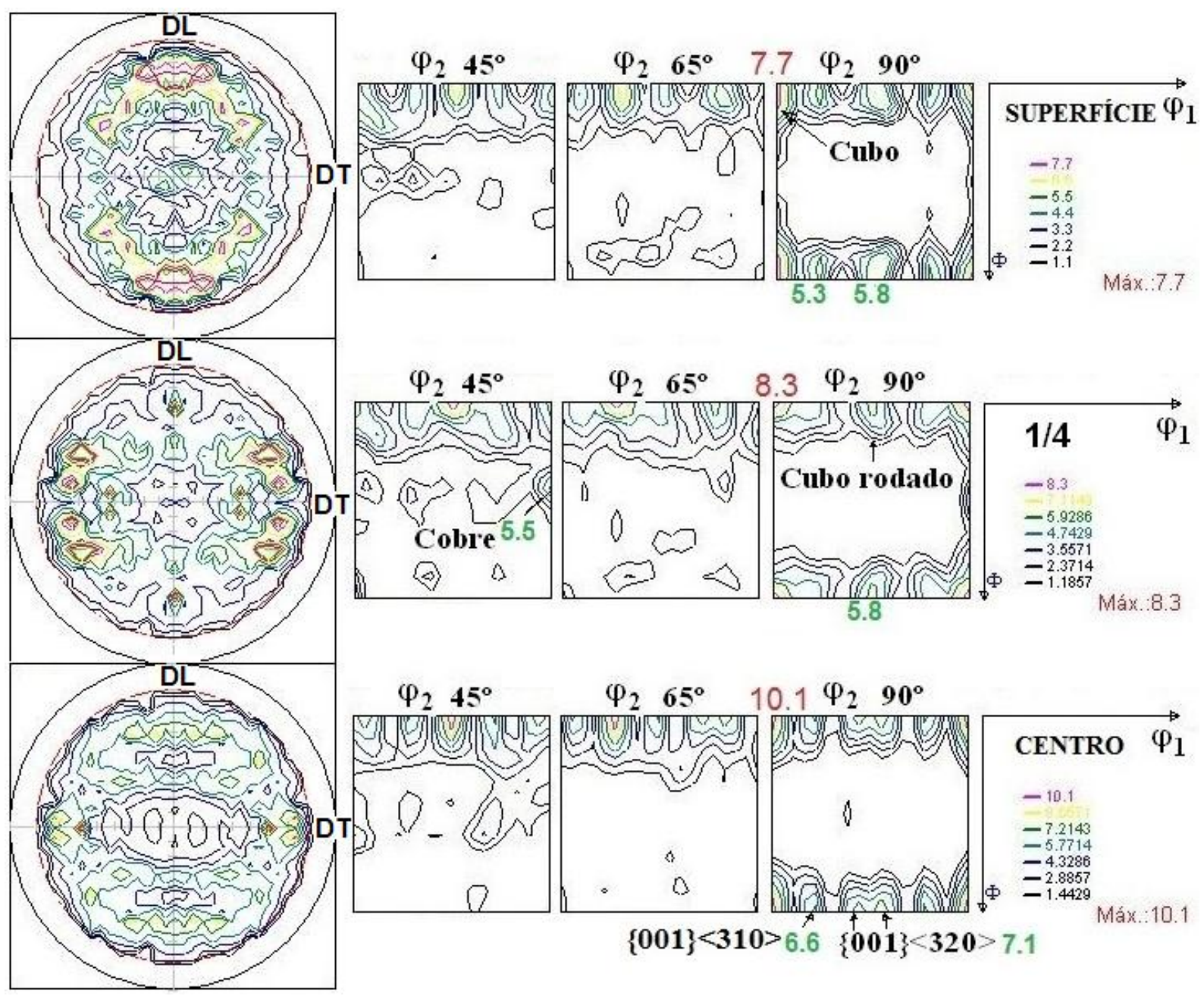

Figura 4.13 - Figuras de pólo (111) e FDO's para a superfície, 1/4 e centro da chapa produzida pelo processo $D C$ da liga AA4006.

$\mathrm{Na}$ Figura 4.13 pode ser visto que as componentes de textura vistas na chapa produzida pelo processo $D C$ também são vistas na chapa produzida pelo processo TRC da liga AA4006, porém as componentes Goss, S e latão não aparecem na chapa produzida pelo processo $D C$. É interessante observar que na superfície a 
componente cubo rodado (textura de cisalhamento) aparece com maior intensidade em relação a esta mesma componente nas regiões de $1 / 4$ e $\quad 1 / 2$ da espessura, isto, quando as intensidades das componentes cubo e cubo rodado são comparadas proporcionalmente. Este comportamento sugere que o fenômeno envolvendo a textura de cisalhamento e a textura de deformação planar, detectado na chapa produzida pelo processo $T R C$, pode acontecer na chapa produzida pelo processo $D C$, mas com menor intensidade, já que nesta última chapa os tratamentos térmicos e/ou mecânicos envolvidos (discutido anteriormente) durante a produção da mesma são diferentes dos que ocorrem na chapa produzida durante o processo TRC.

As texturas cristalográficas em chapas produzidas pelo processo $D C$, com laminação a quente (usando laminador duo reversível), das ligas de alumínio de pureza comercial AA1100, AA1050 e AA1070, foram caracterizadas, e, uma variação da textura ao longo da espessura também foi vista nestas ligas (OLIVEIRA, 2009), bem como na liga AA3003 produzida pelo mesmo processo (MARTINS, 2005), conforme apresentado na Tabela 4.5. Vale ressaltar que no alumínio e em suas ligas predominam as componentes de textura de deformação cobre, latão, Goss, $\mathrm{S}$ e de recristalização, textura cubo (a textura cubo é típica de recristalização e depende da pureza da liga), sendo que, as intensidades destas componentes podem variar muito com as condições de processamento (PADILHA; SICILIANO, 2005).

Tabela 4.6 - Componentes de textura ao longo da espessura de chapas produzidas pelo processo DC (laminadas a quente) das ligas AA1100, AA1050, AA1070 (OLIVEIRA, 2009) e AA3003 (MARTINS, 2005).

\begin{tabular}{llll}
\hline Ligas & Superfície & $1 / 4$ & Centro \\
\hline AA1100 & fibra $\{113\}$ & cubo e latão & cubo e latão \\
AA1050 & fibra $\{113\}$ & cubo & cubo \\
AA1070 & fibra $\{113\}$ & cubo rodado e cubo & cubo \\
AA3003 & cubo rodado & latão & cubo rodado
\end{tabular}

Resumidamente, as chapas da liga AA4006 obtida por lingotamento contínuo e semicontínuo apresentam uma textura de cisalhamento na região bem próxima à superfície, causada pelo atrito entre o cilindro de laminação e a superfície da chapa metálica, já nas regiões mais internas das chapas, o aparecimento das texturas de 
deformação pode ser causado pelas mudanças geométricas, advindas da deformação e do gradiente de temperatura envolvidos nos processos de produção, devido à ocorrência dos estados de deformação heterogêneos em diferentes camadas ao longo da espessura das chapas. Finalmente, deve-se lembrar que os valores de intensidade das texturas também é dependente do programa computacional empregado na análise.

\subsection{Extração dos precipitados nas amostras das duas chapas no estado 'como recebido'}

Precipitados ou partículas das diferentes fases presentes nas microestruturas de ligas de alumínio podem ser extraídos e estudados para melhor compreensão da forma e constituição dos mesmos (GOULART et al, 2010).

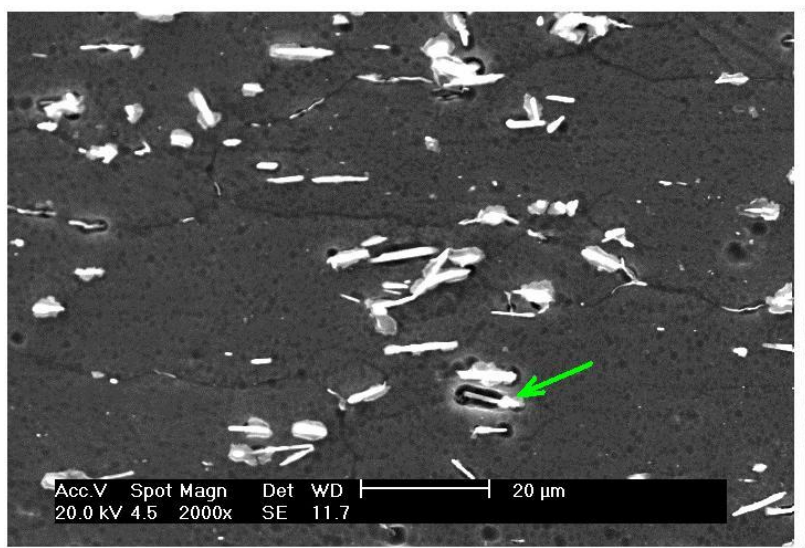

(a) DC, direção transversal

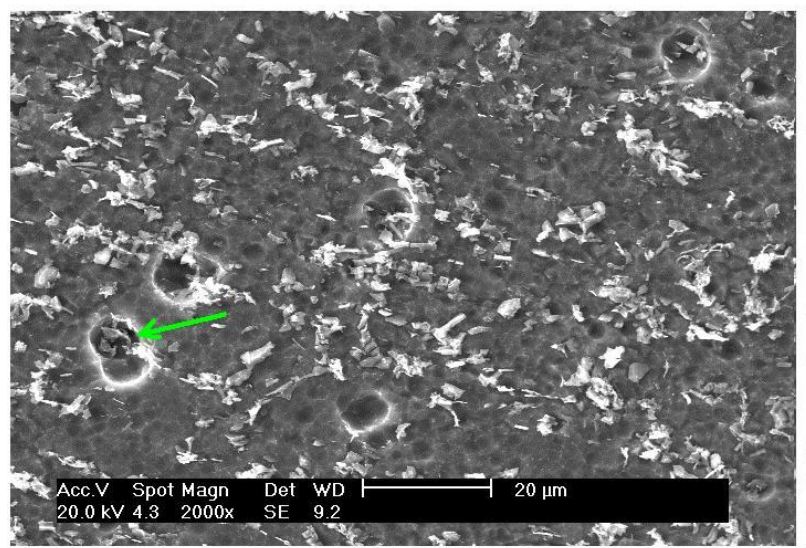

(c) TRC, próximo á superfície

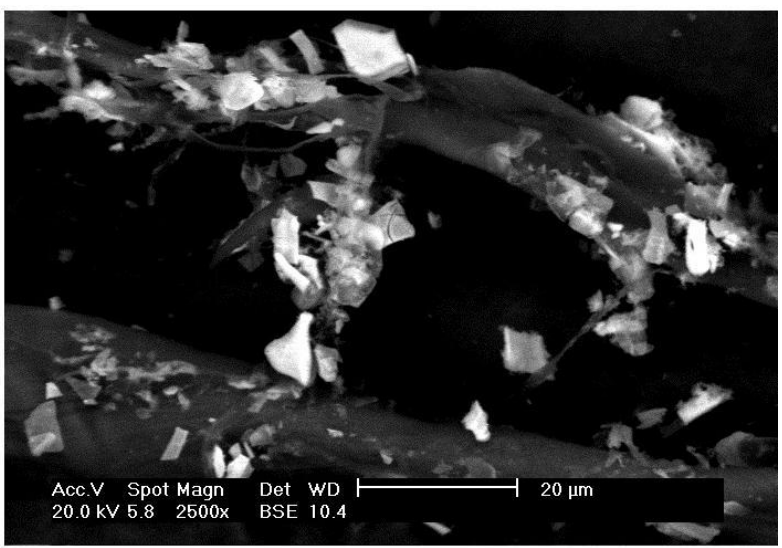

(b) DC

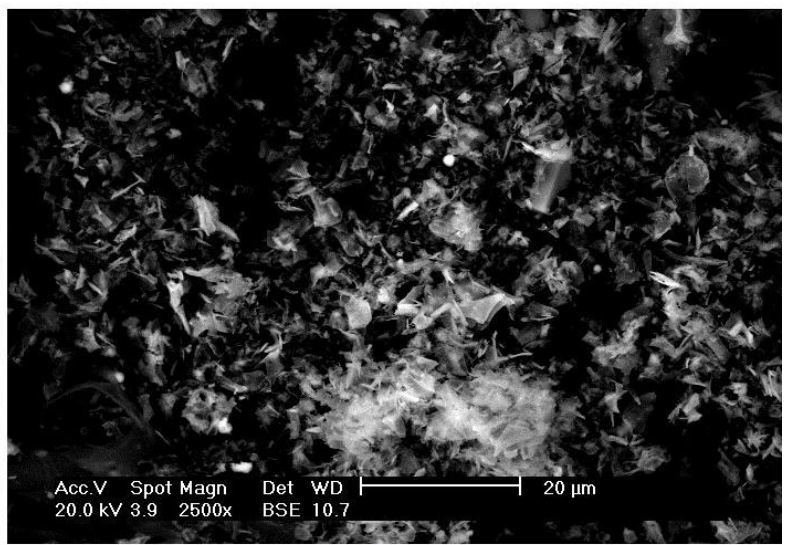

(d) TRC

Figura 4.14 - Micrografias obtidas por ataque profundo nas amostras das duas chapas (a) e (c) e micrografias dos precipitados extraídos destas amostras (b) e (d). 
Na Figura 4.14 estão dispostas as micrografias obtidas por MEV, a partir das quais, podem ser vistos o tamanho dos precipitados, a morfologia e a distribuição destas partículas na microestrutura das chapas obtidas pelos dois processos.
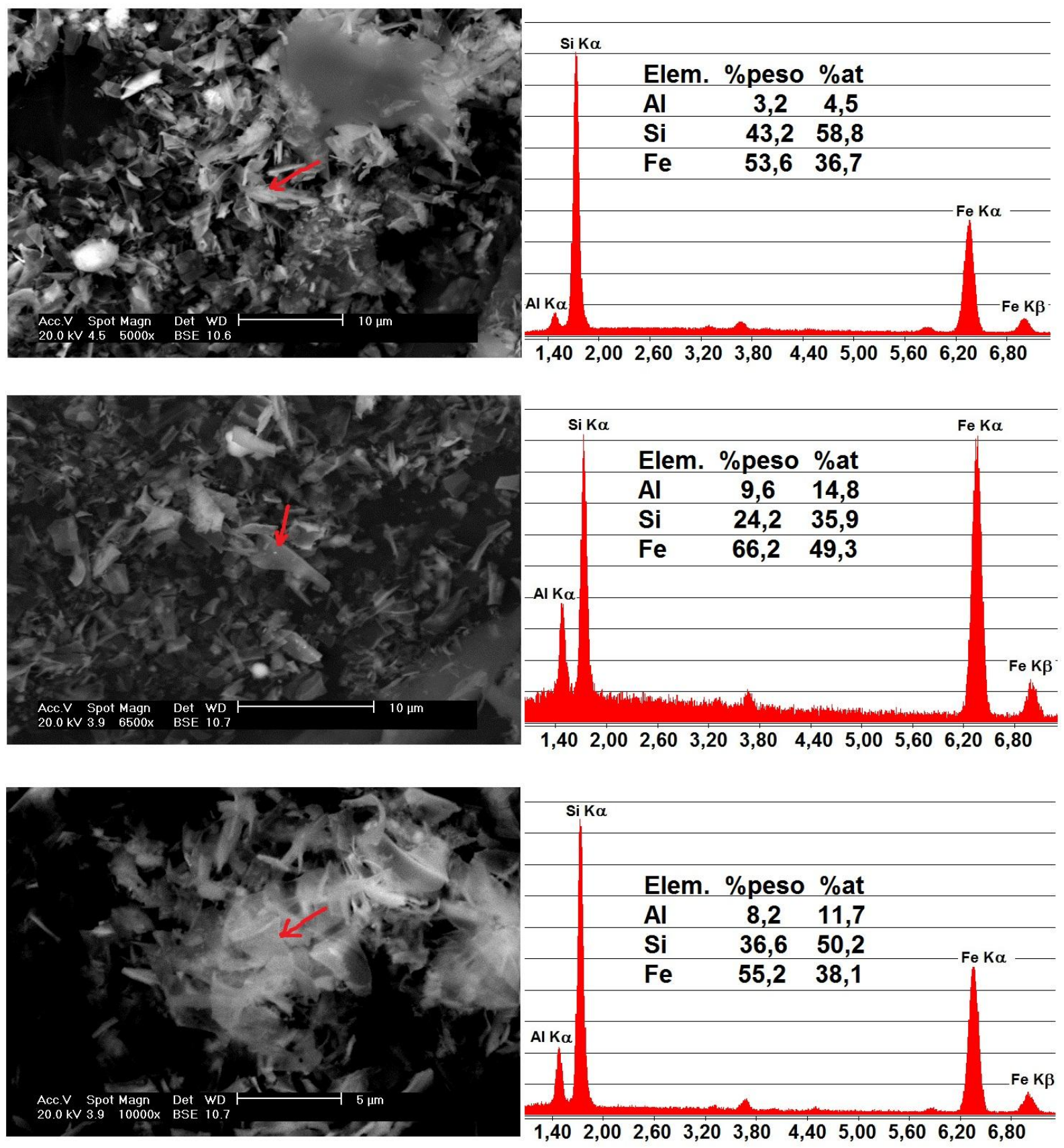

Figura 4.15 - Aglomerados de precipitados encontrados em amostras da chapa da liga AA4006 (no estado como recebido) obtida pelo processo TRC com seus respectivos espectros de dispersão de energia (EDS) destes precipitados indicados pelas setas nas micrografias. 

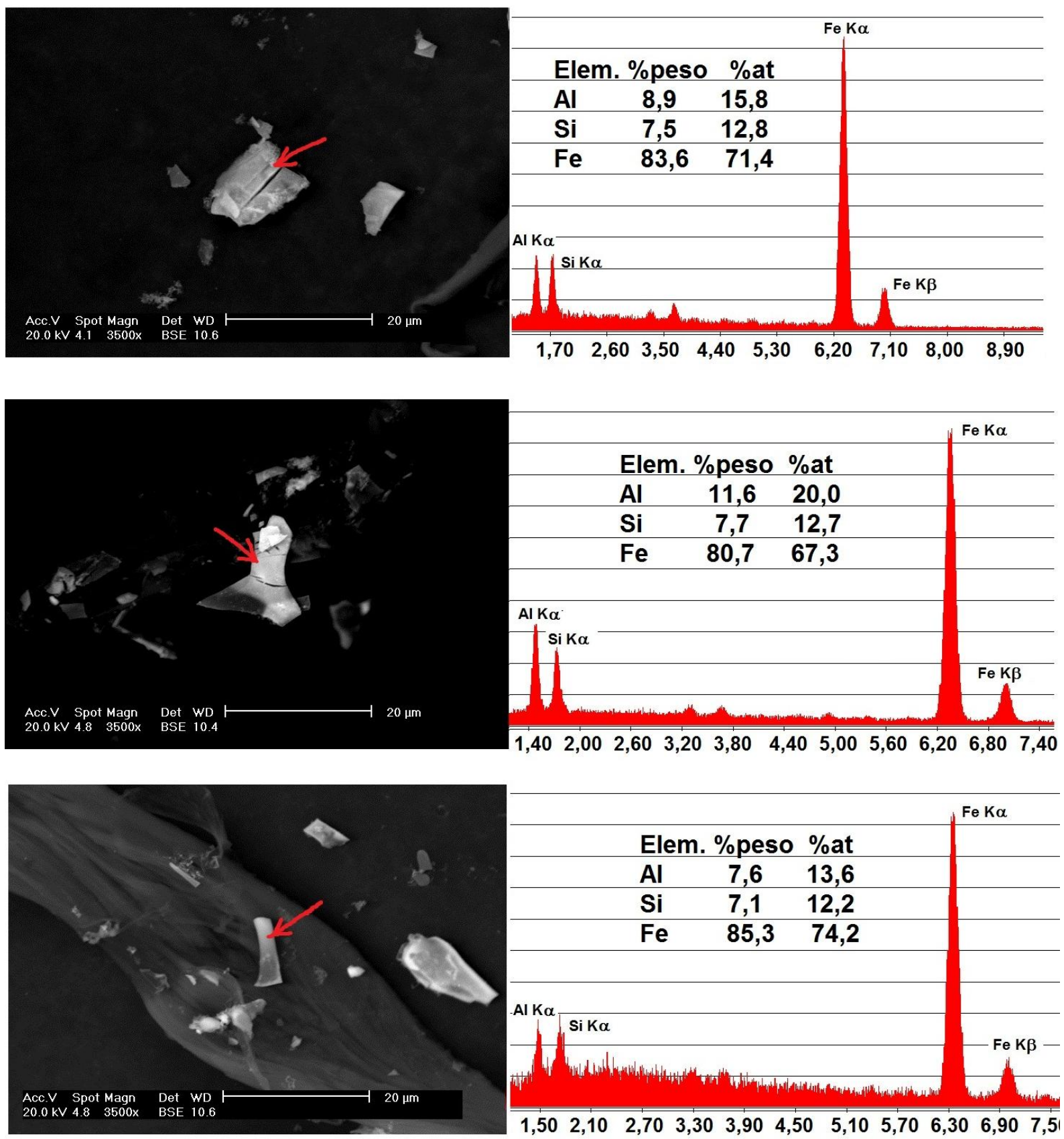

Figura 4.16 - Precipitados encontrados em amostras da chapa da liga AA4006 (no estado como recebido) obtida pelo processo $D C$ com seus respectivos espectros de dispersão de energia (EDS) destes precipitados indicados pelas setas nas micrografias.

Nas Figuras 4.15 e 4.16 podem ser vistos que diferentes fases ou precipitados ternários e ou aglomerado de precipitados com distintos percentuais de cada elemento, principalmente na "chapa $T R C$ ", podem ser encontrados nas duas 
chapas.

Para a obtenção desses precipitados, extraídos da liga AA4006 nas duas chapas, foi utilizada uma solução aquosa $(50 \mathrm{~mL})$ com hidróxido de sódio $(5 \mathrm{~g})$ e com ferricianeto de potássio $(5 \mathrm{~g})$. Os precipitados extraídos foram lavados e filtrados com água destilada. Nas Figuras 4.14, 4.15 e 4.16 pode ser visto que os precipitados se encontram na forma de plaquetas e que as regiões (como as indicadas por setas na cor verde) próximas às partículas são mais corroídas ou atacadas pela solução, como pode ser visto nas micrografias na Figura 4.14a e 4.14c. É razoável salientar que nestas regiões há uma alta densidade de defeitos cristalinos, como discordâncias, que surgiram durante o processamento das chapas. Portanto, para uma análise mais precisa e detalhada dos precipitados, como por exemplo, na obtenção da composição química de cada precipitado, há a necessidade da utilização de técnicas complementares de microanálise química, bem como de difração de raios $\mathrm{X}$, para adquirir os parâmetros de rede de cada fase, além disso, deve haver um minucioso procedimento de separação do precipitado durante a extração, e depois de extraído, para não contaminá-lo quer seja com o solvente usado na extração quer seja com a matriz de alumínio.

\subsection{Recristalização e microdureza nas amostras das duas chapas laminadas a frio e recozidas}

A migração dos contornos de grão durante o recozimento de uma liga metálica é dificultada, devido à dispersão de precipitados e/ou átomos de soluto, pois parte do potencial termodinâmico disponível para a recristalização é consumida na passagem do contorno de grão através da partícula. Os solutos tendem a formar atmosferas de átomos em solução sólida próximas das discordâncias, dificultandose a movimentação e o rearranjo destas, devido à força retardadora de arraste que aparece (PADILHA; SICILIANO, 2005).

A Figura 4.17 apresenta a mudança da dureza nas amostras da liga de alumínio AA4006 produzidas pelos processos $D C$ e $T R C$ laminadas a frio (encruadas), com redução de 70\%, à medida que a temperatura é aumentada. Essa Figura apresenta também as micrografias captadas por microscopia óptica (da distribuição dos precipitados) das 'amostras TRC e $D C$ ' (laminadas e tratadas termicamente a $400{ }^{\circ} \mathrm{C}$ durante 1 hora) antes $\left(150{ }^{\circ} \mathrm{C}\right)$ e após $\left(400{ }^{\circ} \mathrm{C}\right)$ a 
recristalização das mesmas. As partes na cor cinza escuro são os precipitados. A amostra da "chapa $T R C$ ", laminada a frio seguida de tratamentos térmicos, evidenciou uma queda dos valores de dureza posterior, porém, mais acentuada do que a amostra produzida pelo processo $D C$ (Figura 4.17), isto indica que, para a chapa produzida pelo processo $T R C$, a nucleação da recristalização foi dificultada, e, o intervalo de temperatura para a recristalização é um pouco menor que na "chapa $D C^{\prime \prime}$, isto é, a cinética de recristalização é favorecida nesta primeira. A ocorrência de precipitação antes da recristalização pode ter causado o atraso na recristalização da liga produzida por TRC. Esta hipótese será estudada e testada neste trabalho com auxílio de medidas de condutividade elétrica.

$\mathrm{Na}$ tabela 4.7 podem ser vistos os resultados de microdureza Vickers obtidos em diferentes temperaturas (com suas respectivas faixas de erros) usados para plotar as curvas vistas na Figura 4.17.

Tabela 4.7 - Medidas de microdureza Vickers das amostras das chapas obtidas pelos processos $D C$ e TRC da liga AA4006 tratadas em diferentes temperaturas durante uma hora.

\begin{tabular}{llllllllll}
\hline HV & $30\left({ }^{\circ} \mathrm{C}\right)$ & 150 & 250 & 300 & 350 & 400 & 450 & 500 & 550 \\
\hline TRC & 63,5 & 60,5 & 58,4 & 43,9 & 33,8 & 33,7 & 34,0 & 35,2 & 36,7 \\
& $\pm 0,4$ & $\pm 0,4$ & $\pm 0,5$ & $\pm 0,5$ & $\pm 0,2$ & $\pm 0,2$ & $\pm 0,3$ & $\pm 0,1$ & $\pm 0,2$ \\
DC & 63,1 & 61,0 & 52,6 & 38,8 & 30,5 & 29,5 & 28,3 & 30,7 & 32,9 \\
& $\pm 0,3$ & $\pm 0,4$ & $\pm 0,6$ & $\pm 0,6$ & $\pm 1,8$ & $\pm 0,3$ & $\pm 0,3$ & $\pm 0,2$ & $\pm 0,2$ \\
\hline
\end{tabular}




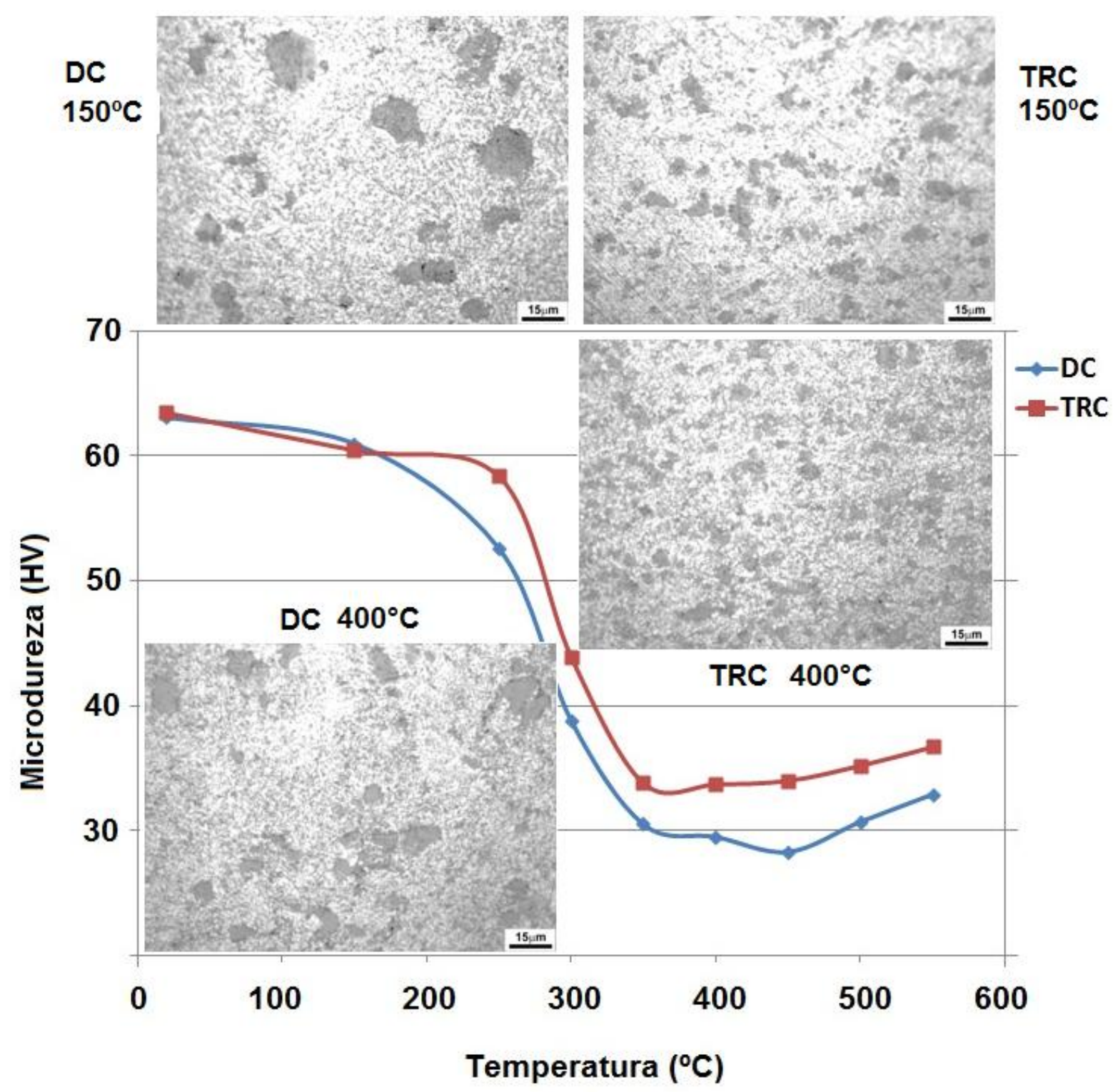

Figura 4.17 - Curvas da variação da microdureza (HV) das amostras obtidas das chapas produzidas pelos processos $D C$ e TRC da liga AA4006 laminadas a frio com $70 \%$ de redução em área, em função da temperatura e micrografias das distribuições dos precipitados antes e após a recristalização.

A força retardadora atribuída às partículas distribuídas nas microestruturas das chapas dificulta a movimentação dos subcontornos de grão, atrasando-se o início da recristalização na chapa produzida pelo processo TRC (com precipitados de distribuição mais fina que na 'chapa $D C$ '). Isto sugere que a quantidade maior de Si e Fe nesta chapa (ver Tabela 4.1) do que na chapa produzida pelo processo $D C$ (com precipitados maiores e mais separados que na 'chapa TRC) contribui para o atraso da nucleação da recristalização na "chapa $T R C$ ". Além disso, partículas mais 
finas (como visto na Figura 4.17) e distribuídas, homogeneamente, levam ao aumento da distribuição de defeitos ancorando os subcontornos, e, conseqüentemente, dificultando a nucleação para a recristalização. Logo, na "chapa $T R C^{\prime}$, uma vez nucleados os grãos, a recristalização acontece numa faixa de temperatura menor que na "chapa $D C$ ", pois a energia armazenada na deformação (potencial termodinâmico disponível para ocorrência da recristalização) é maior nesta primeira chapa. Pode ser sugerido que na amostra da chapa $D C$ há a ocorrência dos fenômenos da recuperação numa maior faixa de temperatura que na $T R C$, pois a recristalização da chapa $D C$ inicia antes da $T R C$ e termina quase que na mesma temperatura da TRC. Assim, em temperaturas maiores que 0,2 da temperatura de fusão absoluta, pode ocorrer a aniquilação de intersticiais e lacunas e a migração de defeitos puntiformes para os contornos e para as discordâncias. Em temperaturas entre 0,2 e 0,3 pode haver a possibilidade de rearranjo e anulação de discordâncias de sinais opostos delineando contornos de baixo ângulo, já em temperaturas maiores que 0,4 da temperatura de fusão absoluta ocorre a formação de subgrãos.

Na Figura 4.18 pode ser visto o diagrama TTT esquemático (Figura 4.18a), que indica o comportamento de uma liga (Al-Mn-Si-Fe) supersaturada, que foi deformada a frio e depois recozida em diferentes tempos e temperaturas (Figura 4.18b), englobando-se a ocorrência da precipitação e da recristalização, as quais podem acontecer simultaneamente ou não. Nas temperaturas de tratamento térmico acima de $T_{1}$ ocorre apenas recristalização com o decorrer do tempo, já entre $T_{1}$ e $T_{2}$ a recristalização acontece antes, por fim, abaixo de $\mathrm{T}_{2}$ é a precipitação que acontece primeiro (Figura 4.18a), a qual influi no arranjo de discordâncias durante a recuperação, na migração dos contornos de baixo ângulo, bem como dos contornos de alto ângulo, causando atraso na recristalização (KOSTER, 1974; TANGEN et al, 2010). 


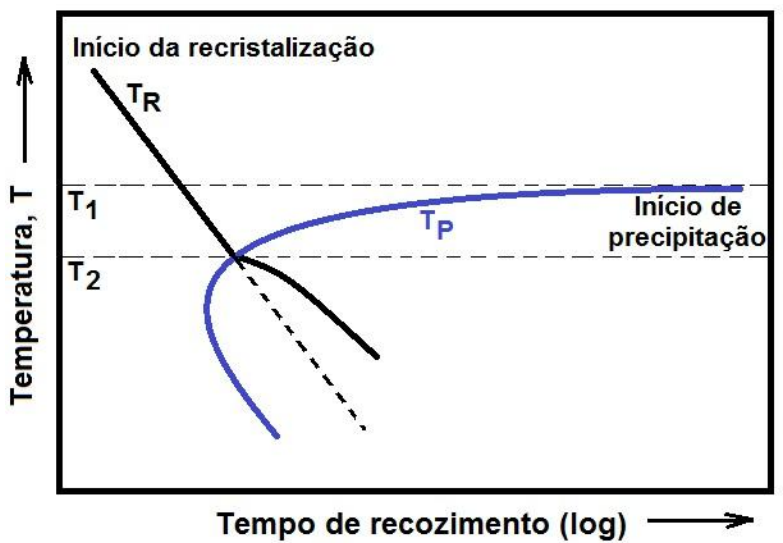

(a)

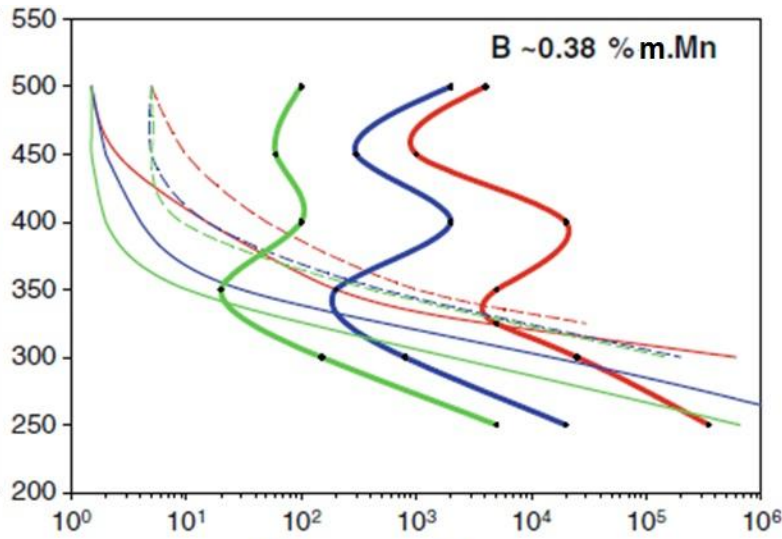

(b) Tempo $[\mathrm{s}]$

Figura 4.18 - Diagrama esquemático de tempo, temperatura e transformação (TTT) (KOSTER, 1974) (a) e diagramas TTT de uma liga (Al-Mn-Fe-Si) que foi inicialmente submetida ao tratamento térmico de solubilização (supersaturada), em seguida foi deformada a frio e finalmente recozida (TANGEN et al, 2010) (b).

$\mathrm{Na}$ Figura 4.18b o inicio da recristalização está representado pelas linhas delgadas, o fim, pelas linhas pontilhadas e o começo da precipitação pelas linhas espessas, bem como as cores vermelha, azul e verde representam as deformações verdadeiras de 0,5, 1,5 e 3,0, respectivamente. Na Figura 4.18b também pode ser visto que para altas taxas de resfriamento (> $3^{\circ} \mathrm{C} / \mathrm{s}$, por exemplo) não há a ocorrência de precipitação.

A Tabela 4.8 apresenta as condutividades elétricas das amostras, com $70 \%$ de redução em área e tratadas termicamente nas temperaturas de 150, 250, 300, $350,400,450,500$ e $550 \stackrel{\circ}{C}$ por 1 hora. As curvas de amolecimento destas amostras e a temperatura de recristalização podem ser vistas na Figura 4.17.

Tabela 4.8 - Condutividades elétricas de amostras das chapas obtidas pelos processos $D C$ e TRC da liga AA4006 tratadas em diferentes temperaturas durante uma hora.

\begin{tabular}{llllllllll}
\hline IACS(\%) & $30\left({ }^{\circ} \mathrm{C}\right)$ & 150 & 250 & 300 & 350 & 400 & 450 & 500 & 550 \\
\hline TRC & 52,7 & 52,3 & 57,0 & 57,3 & 58,3 & 57,5 & 55,7 & 53,7 & 51,2 \\
& $\pm 0,3$ & $\pm 0,5$ & $\pm 0,2$ & $\pm 0,4$ & $\pm 0,1$ & $\pm 0,2$ & $\pm 0,2$ & $\pm 0,1$ & $\pm 0,1$ \\
\multirow{2}{*}{ DC } & 52,6 & 53,4 & 58,3 & 58,1 & 58,6 & 57,9 & 56,6 & 53,1 & 52,0 \\
& $\pm 0,3$ & $\pm 0,1$ & $\pm 0,2$ & $\pm 0,3$ & $\pm 0,2$ & $\pm 0,1$ & $\pm 0,1$ & $\pm 0,4$ & $\pm 0,2$ \\
\hline
\end{tabular}


Com base nesta tabela, pode-se dizer que a precipitação na amostra da 'chapa $T R C$, laminada a frio com $70 \%$ de redução, acontece principalmente antes da recristalização, podendo haver um pouco de ocorrência também durante a recristalização, e na amostra da 'chapa $D C$ ' há possibilidade da ocorrência da precipitação antes e durante a recristalização (ver Figura 4.17), pois nas temperaturas entre $150^{\circ} \mathrm{C}$ e $250^{\circ} \mathrm{C}$, nas duas amostras ( $D C$ e $T R C$ ), há um aumento significativo da condutividade elétrica, a qual se mantém alta (por volta de $58 \%$ IACS) até $400 \stackrel{\circ}{\circ}$, voltando-se a cair após esta temperatura. Isto ocorre devido à precipitação do soluto $(\mathrm{Si})$, que volta a se dissolver na matriz em temperaturas acima de $400 \stackrel{\circ}{\circ}$. Em suma, as medidas de condutividade elétrica corroboram a suposição de que a ocorrência de precipitação, antes da recristalização na liga produzida por $T R C$, contribuiu para dificultar o rearranjo das discordâncias e a migração de sub-contornos, postergando o início da recristalização.

$\mathrm{Na}$ chapa da liga de alumínio AA4006 (supersaturada no estado 'como recebido') obtida pelo processo TRC há a ocorrência de precipitados com diferentes distribuições, ao longo da espessura, já que a taxa de resfriamento durante a solidificação do metal pode influenciar na agregação dos elementos constituintes das partículas ao longo da espessura do material (Figura 4.4). Assim, a recristalização da "chapa $T R C$ " pode ser atrasada, caso a precipitação ocorra primeiro.

A nucleação da recristalização em regiões próximas às partículas foi estudada inicialmente por Doherty e Martin (1962-63), e, estes estudos foram posteriormente detalhados por Humphreys (1977), que concluiu que a recristalização se origina em regiões de alta densidade de defeitos, como discordâncias (discutido neste trabalho, com base nas micrografias da Figura 4.14a e 4.14c.), e com elevados ângulos de desorientação entre grãos. Assim, a recristalização segue com um processo rápido de poligonização que pode resultar em grãos com orientações próximas das orientações dos grãos na estrutura anteriormente deformada. O espaçamento entre as partículas e o diâmetro da partícula também podem influenciar no processo de recristalização (DOHERTY, MARTIN, 1962-63; HUMPHREYS, 1977). Com base nesse contexto, sugere-se que a nucleação em partículas pode ocorrer nas duas chapas produzidas pelos processos $D C$ e TRC, pois na liga de alumínio AA4006 partículas grosseiras (maiores que $1 \mu \mathrm{m}$ ) são vistas em sua microestrutura (Figura 4.14). 


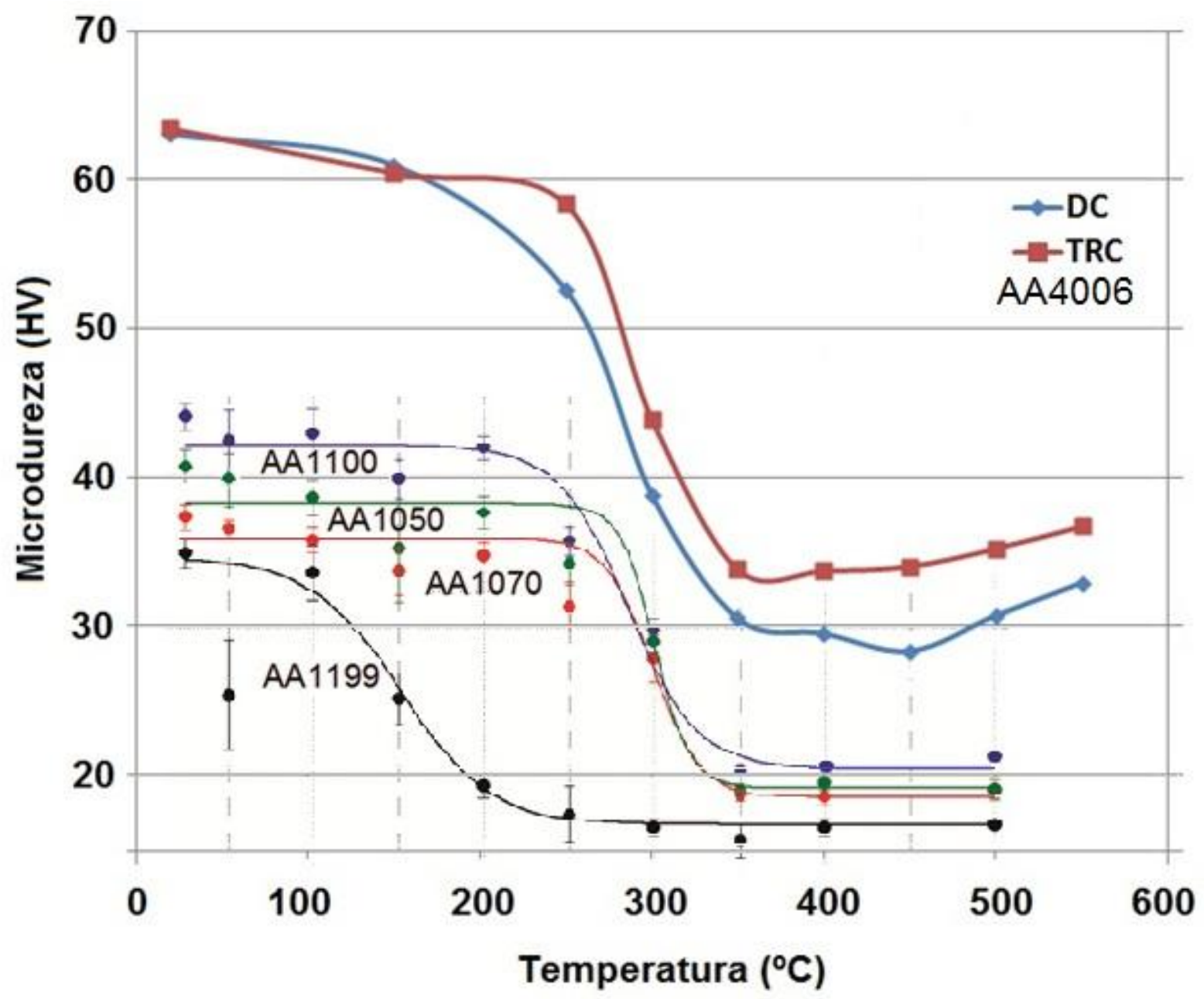

Figura 4.19 - Curvas da variação da microdureza (HV) de alumínios recozidos após laminação a frio com $70 \%$ de redução em área (OLIVEIRA, 2009) e das ligas AA4006 TRC e $D C$, em função das temperaturas do tratamento térmico.

Para efeito de comparação, juntamente com as curvas (da liga AA4006 TRC e $D C)$ da Figura 4.17, a Figura 4.19 apresenta, também, a mudança da microdureza com o aumento da temperatura (curvas de amolecimento) em amostras de diferentes alumínios de pureza comercial (AA1050, AA1070 e AA1100), produzidos pelo processo $D C$, e alumínio de alta pureza, obtido em laboratório, todos eles, laminados a frio (redução de $70 \%$ em área) (OLIVEIRA, 2009).

Ao fazer a comparação das amostras da liga AA4006 produzidas pelos processos $D C$ e TRC (Figura 4.17) com as amostras destes diferentes alumínios de pureza comercial produzidos pelo processo $D C$ (Figura 4.19) pode-se notar que as temperaturas de recristalização destas diferentes ligas de alumínio AA1050, 
AA1070, AA1100 são relativamente parecidas. Já o alumínio de alta pureza, que não apresenta precipitados e/ou átomos de soluto em sua microestrutura, tem um início de queda da dureza, na curva dureza versus temperatura (Figura 4.19), bem abaixo da região de queda nas curvas das ligas AA1050, AA1070, AA1100 e AA4006, evidenciando-se que o soluto retarda a movimentação de contornos de grão, como já discutido. Além disso, a liga AA4006 apresenta uma dureza superior às demais em toda a faixa de temperatura analisada devido aos maiores teores dos solutos $\mathrm{Si}$ e Fe na liga aqui estuda do que nos demais alumínios.

A temperatura de recristalização de uma liga pode ser obtida a partir das curvas apresentadas na Figura 4.20 através da derivada da taxa de variação da microdureza. Assim, os valores aproximados da temperatura para o início da recristalização, bem como para $50 \%$ de amolecimento são facilmente visualizados (Figura 4.20).

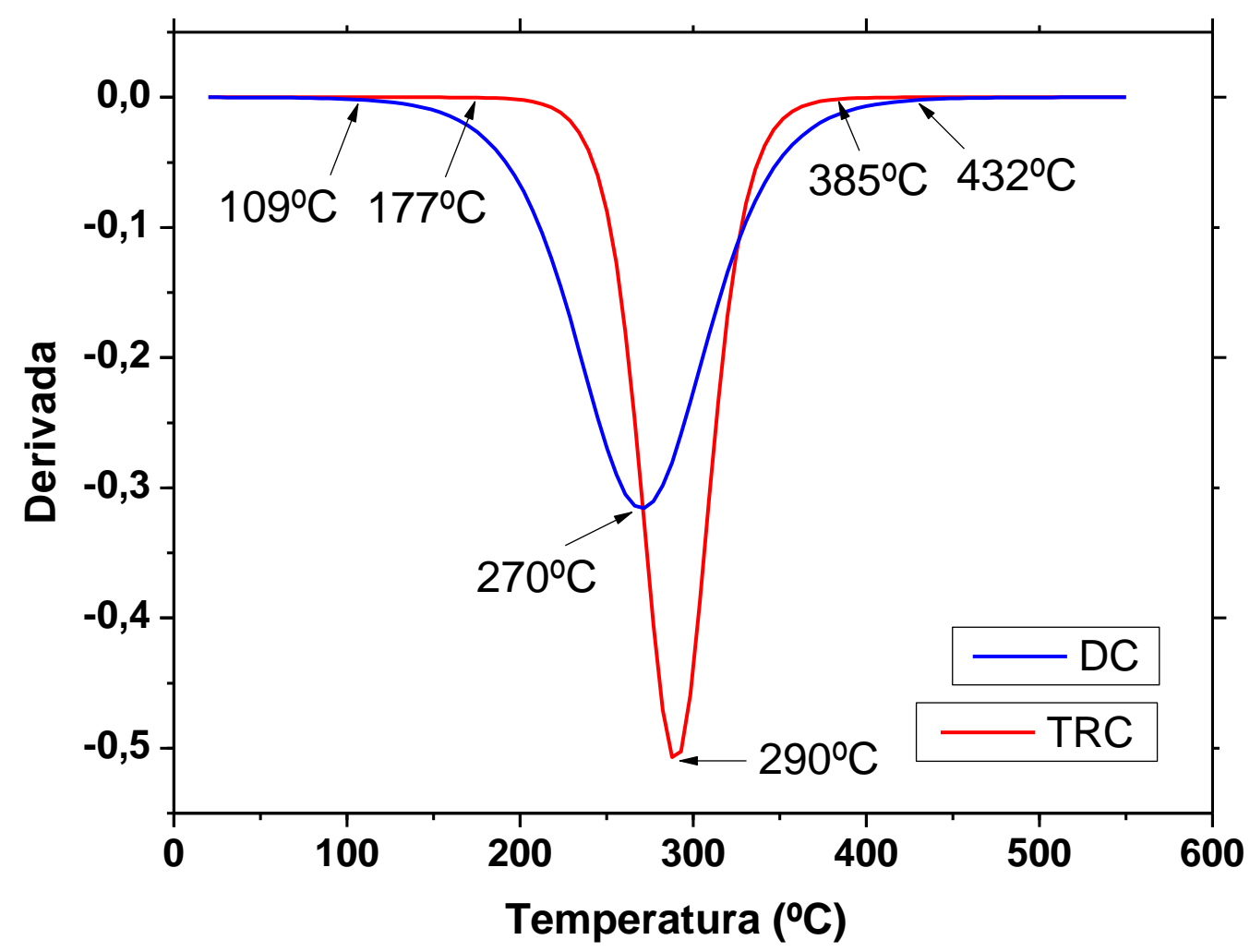

Figura 4.20 - Curvas (derivadas) das taxas de variação da microdureza em função da temperatura $(\mathrm{dHV} / \mathrm{dT})$ para as amostras obtidas das chapas produzidas pelos processos $D C$ e $T R C$ da liga AA4006 laminadas a frio com $70 \%$ de redução em área. 
As temperaturas para $50 \%$ de amolecimento nas amostras foram em torno de $270 \stackrel{\circ}{\circ}$ para a amostra da chapa produzida pelo processo $D C$ e $290 \stackrel{\circ}{\circ}$ para a amostra da chapa produzida pelo processo $T R C$, e, as temperaturas de início da recristalização foram encontradas por volta de $109^{\circ} \mathrm{C}$ e $177^{\circ} \mathrm{C}$, respectivamente (Figura 4.20).

\subsection{Texturas cristalográficas (obtidas por difração de raios X) em amostras das chapas laminadas a frio e recristalizadas}

Durante processamentos térmicos e/ou mecânicos de chapas de diferentes ligas de alumínio a textura cristalográfica pode variar tanto ao longo da espessura quanto com a mudança da temperatura e do grau de deformação na laminação. Neste contexto, numa chapa laminada a frio, seguida de recristalização (recozimento), as componentes de textura, típicas de laminação, podem mudar gradualmente para as componentes de textura, típicas de recristalização durante o recozimento (LIU; MORRIS, 2002; ENGLER; KIM; HUH, 2001).

A lubrificação dos cilindros de laminação e a velocidade de laminação das chapas metálicas também influenciam na mudança da textura, isto é, em estudos anteriores chapas da liga AA1050 apresentaram uma diminuição nas intensidades da textura de cisalhamento com o aumento da velocidade de laminação, além disso, para altas velocidades de laminação, e utilizando lubrificante, a textura mudou significativamente da textura de cisalhamento para a fibra $\beta$ (BENUM; ENGLER; NES, 1994). Vale lembrar que a presença da fibra $\beta$ é muito comum em ligas de alumínio laminadas (ENGLER, 1996; SOUZA et al, 2011).

Na Figura 4.21 pode ser visto que a superfície da amostra laminada, da chapa TRC da liga AA4006, apresentou as componentes de textura $\{001\}<110>$ cubo rodado com maior intensidade, bem como a $\{001\}<100>$ cubo e a $\{001\}<310>$ com intensidades menores. Já na Figura 4.22 pode ser visto que na região central desta amostra a textura típica de laminação, fibra $\alpha$ (envolvendo as componentes latão e Goss), juntamente, com a fibra $\beta$ apareceu, de forma expressiva.

A textura cubo rodado (vista como textura de cisalhamento) e a fibra $\{100\}$ foram encontradas na região superficial da amostra laminada, da chapa $D C$ da liga AA4006, com intensidades baixas, porém, a fibra $\beta$ foi encontrada com intensidade 
mais alta (Figura 4.23). Nesta mesma amostra, pode ser visto que a fibra $\{100\}$ apareceu na região central, com maior intensidade que na superfície, e a fibra $\beta$ foi vista com baixa intensidade no centro (Figura 4.24). A Figura 4.25 apresenta a distribuição da intensidade da fibra $\{100\}$ ao longo de $\Phi$ na superfície e no centro da amostra laminada (com redução de $70 \%$ em área) da chapa produzida pelo processo $D C$. Nesta figura pode ser visto que os valores da intensidade desta fibra, na região central, quase dobram quando comparada com a sua intensidade na região superficial.

Nas Figuras 4.26 e 4.27 as mudanças nos valores de intensidades ( $\mathrm{f}(\mathrm{g})$, nos eixos das ordenadas) das principais componentes de textura, no estado como recebido, após a laminação a frio (com $70 \%$ de redução em área) e no estado recristalizado, podem ser vistas nas amostras (das 'chapas TRC e DC'). Dessa forma, a evolução da textura pode ser comparada entre essas amostras nos três estados diferentes. 
F. P. (111)

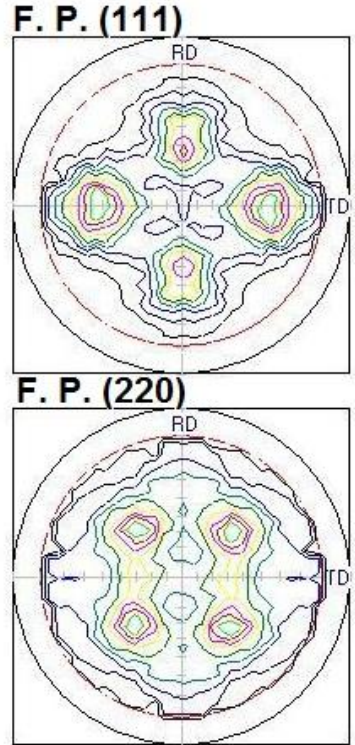

(a)

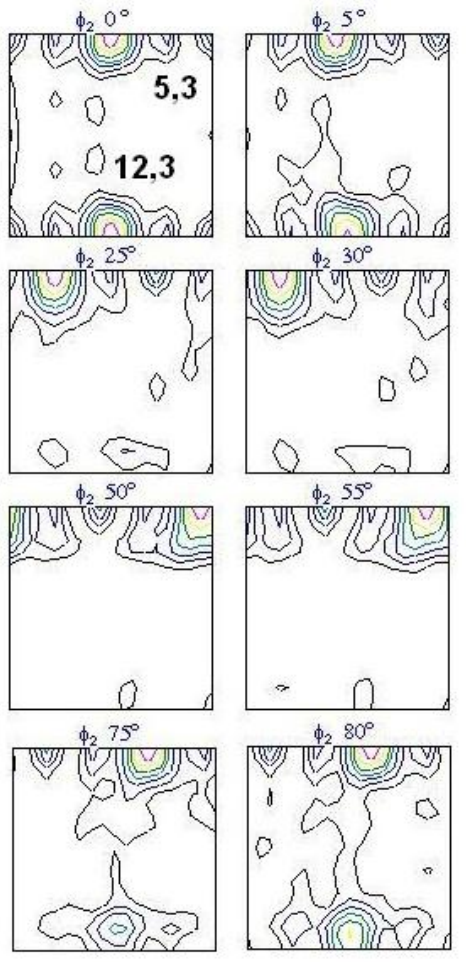

F. P. (200)

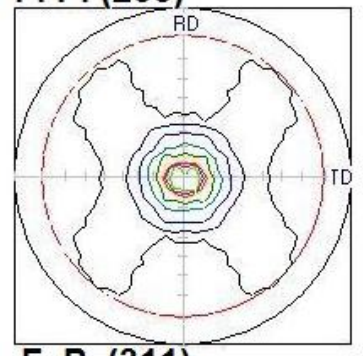

F.P. (311)

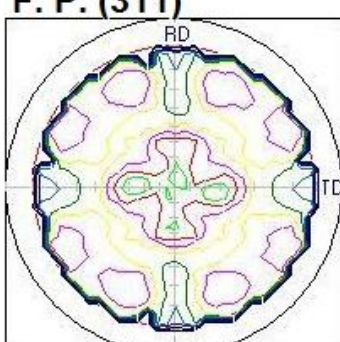

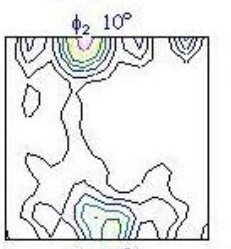
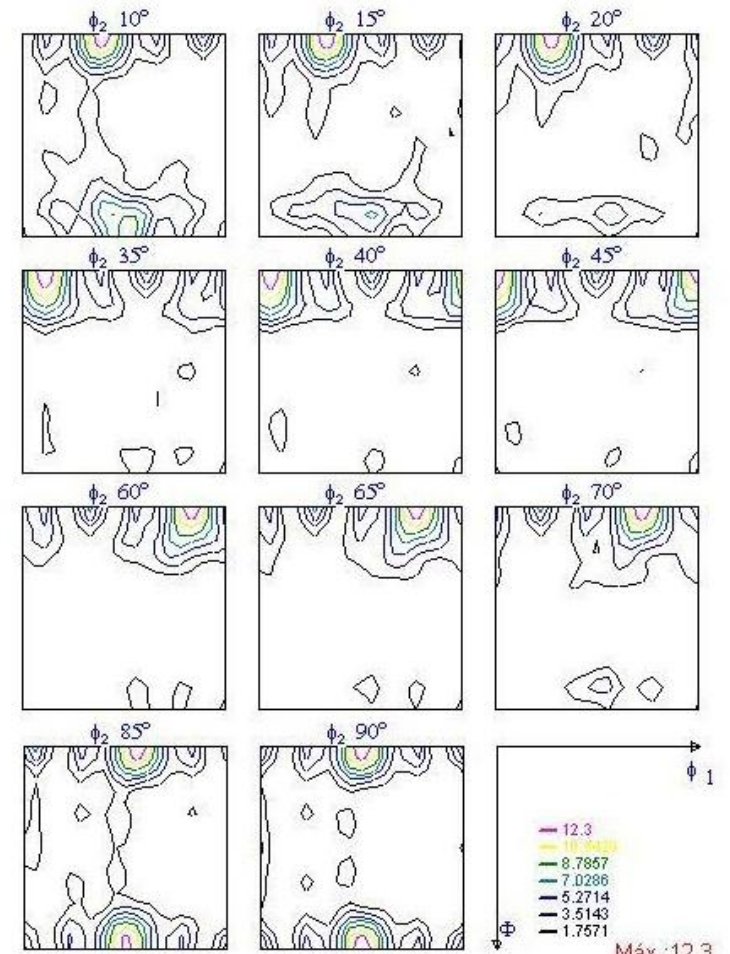

(b)

Figura 4.21 - Figuras de pólo (111), (200), (220) e (311) (a) e FDO's na superfície da amostra laminada com redução de $70 \%$ em área da chapa produzida pelo processo TRC da liga AA4006 (b). 

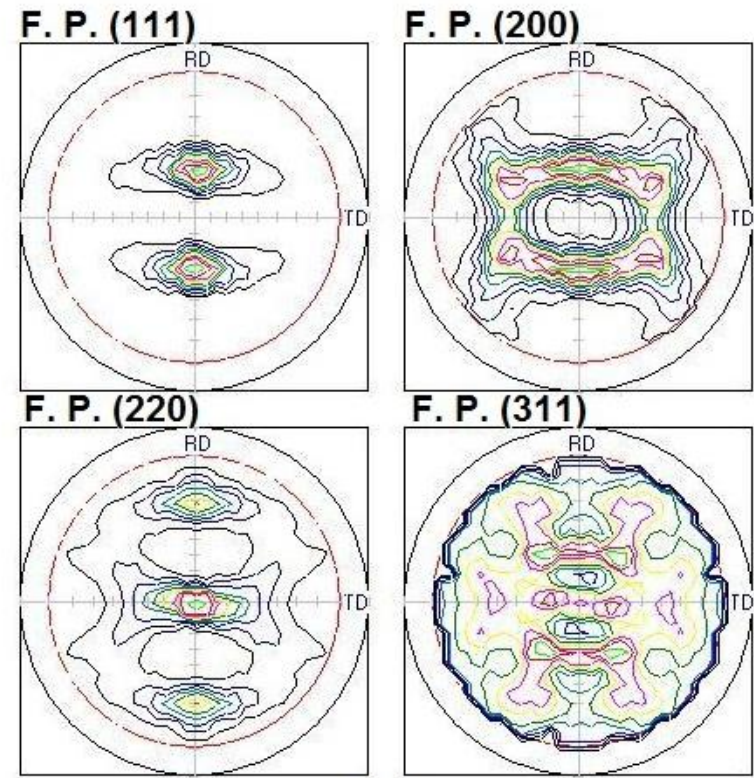

(a)
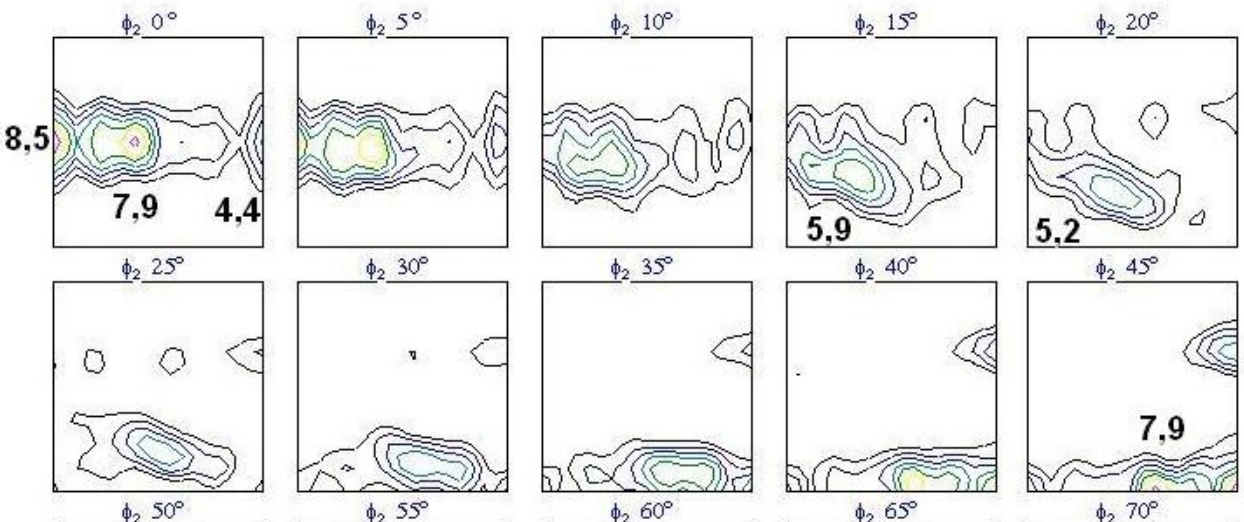

$\phi_{2} 40^{\circ}$

$\phi_{2} 45^{\circ}$
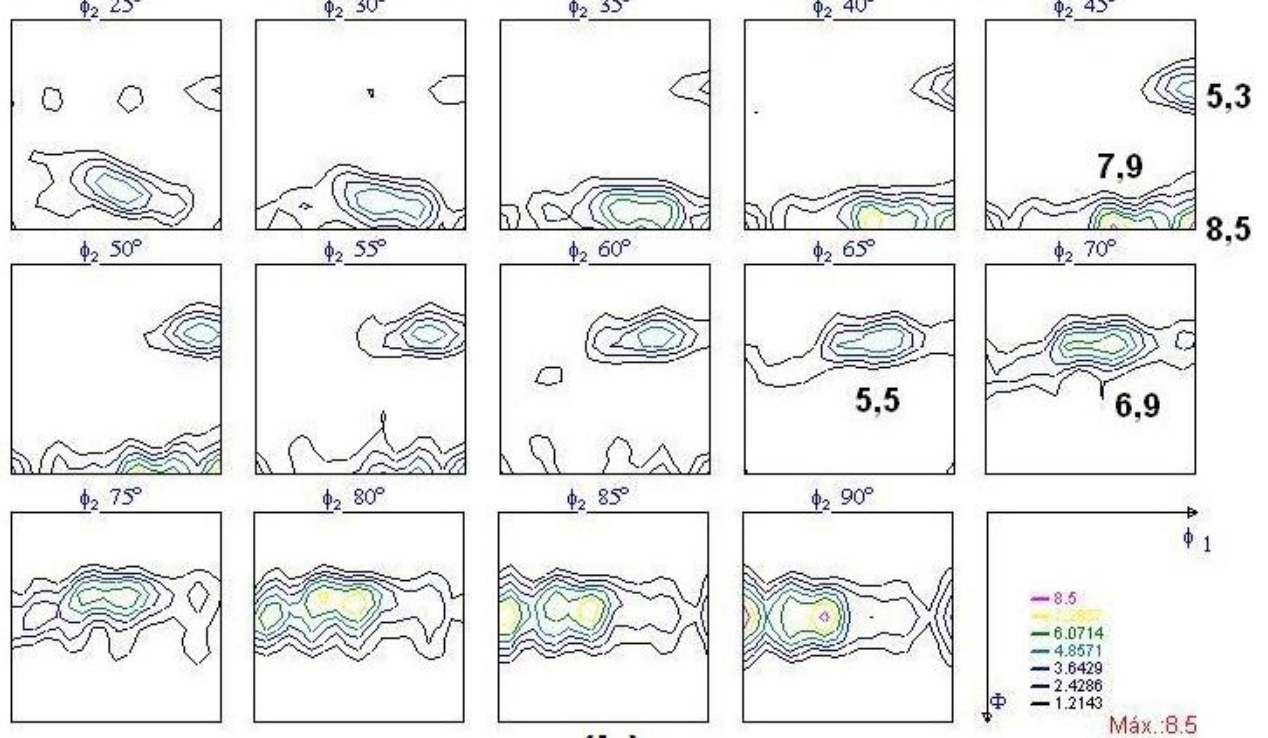

(b)

Figura 4.22 - Figuras de pólo (111), (200), (220) e (311) (a) e FDO no centro da amostra laminada com redução de $70 \%$ em área da chapa produzida pelo processo TRC da liga AA4006 (b). 
F.P. (111)

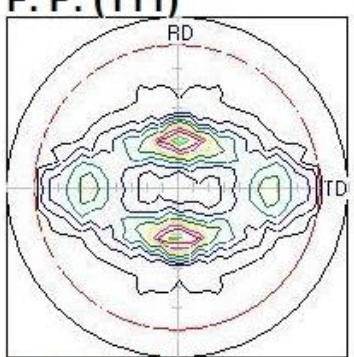

F.P. (220)

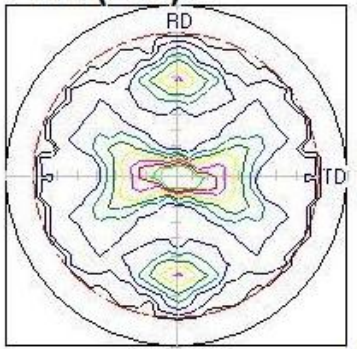

F.P. (200)

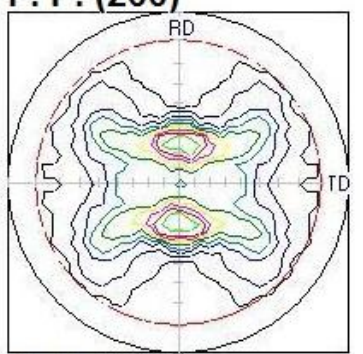

F.P. (311)

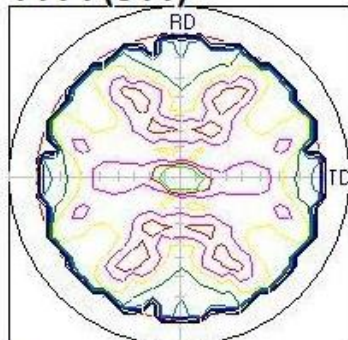

(a)
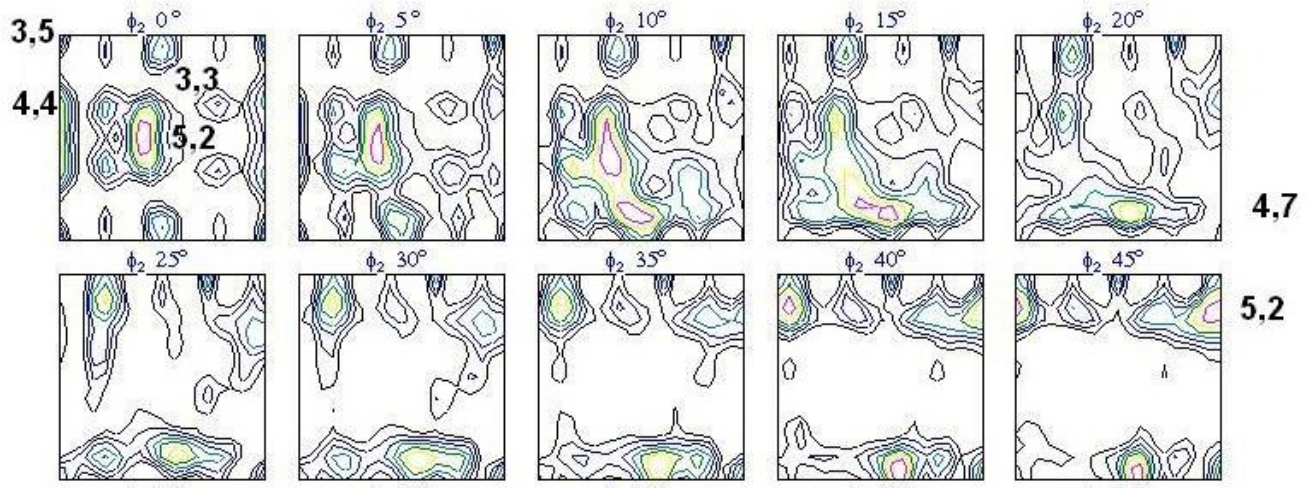

5,2
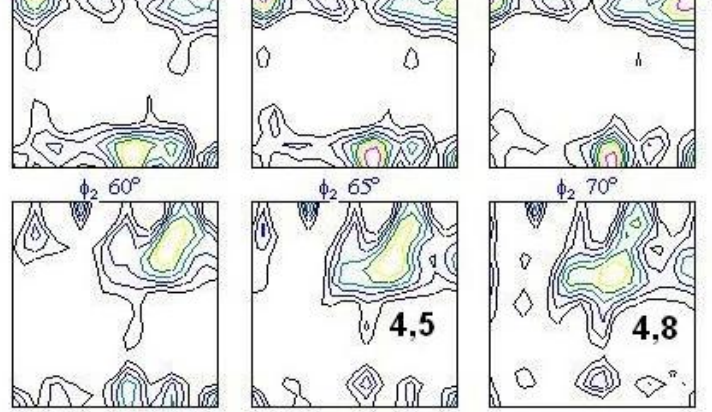

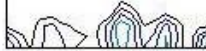

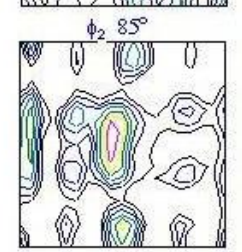

(b)
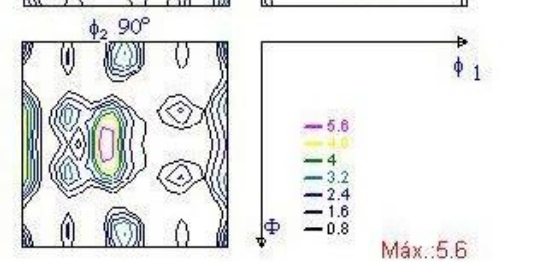

Máx.5.6

Figura 4.23 - Figuras de pólo (111), (200), (220) e (311) (a) e FDO na superfície da amostra laminada com redução de $70 \%$ em área da chapa produzida pelo processo $D C$ da liga AA4006 (b). 
F. P. (111)

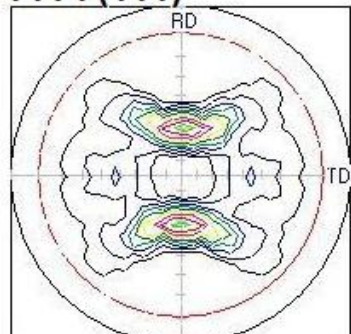

F. P. (220)

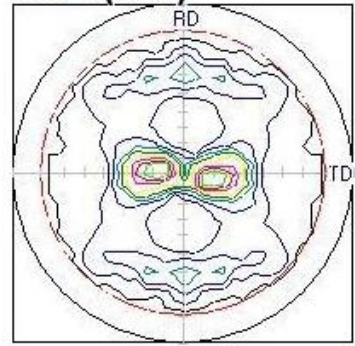

F. P. $(200)$

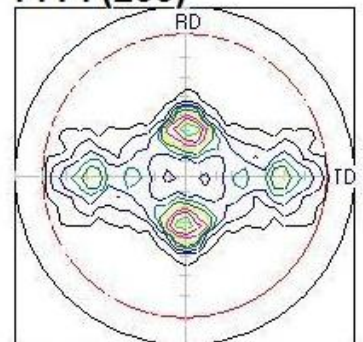

F.P. (311)

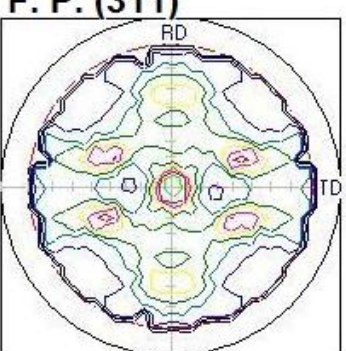

(a)

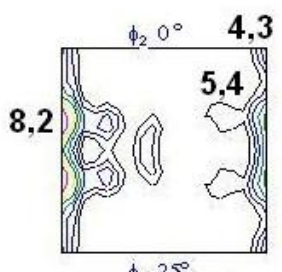

$\phi_{2} 25^{\circ}$
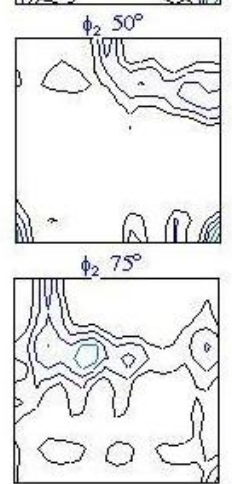

$\phi_{2} 5^{\circ}$

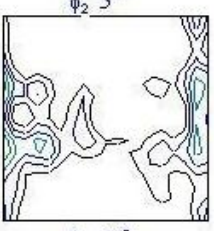

$\phi_{2} \frac{30^{\circ}}{1 W}$

0,00 $\therefore$
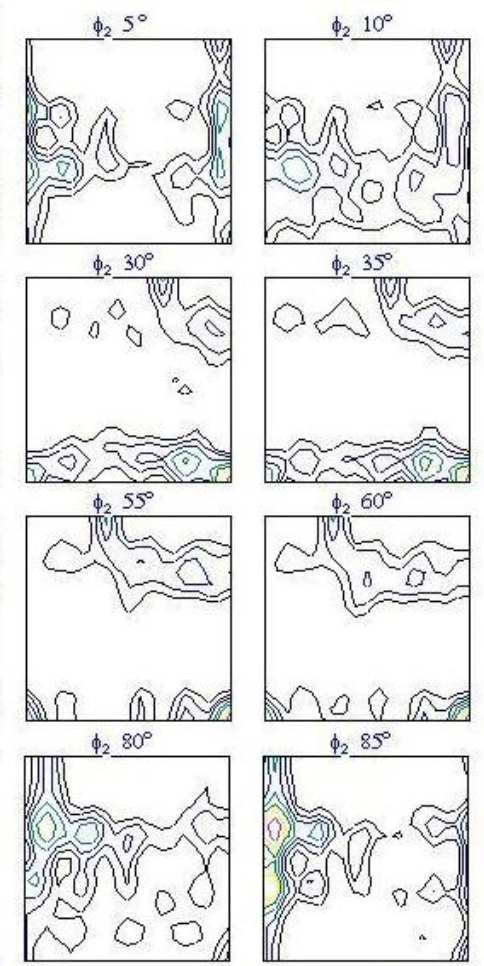

$\phi 285^{\circ}$

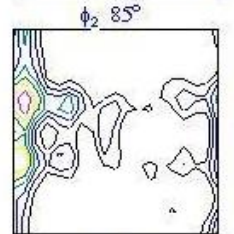

(b)
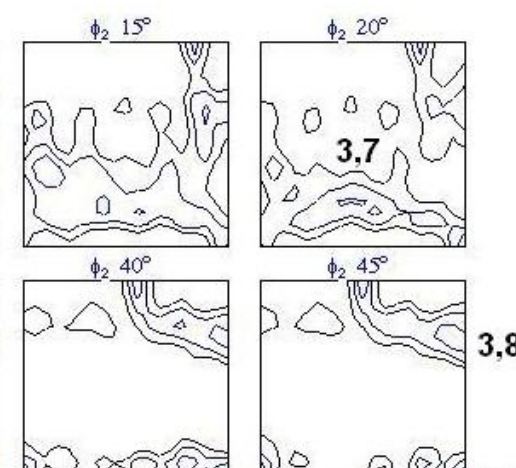

3,8
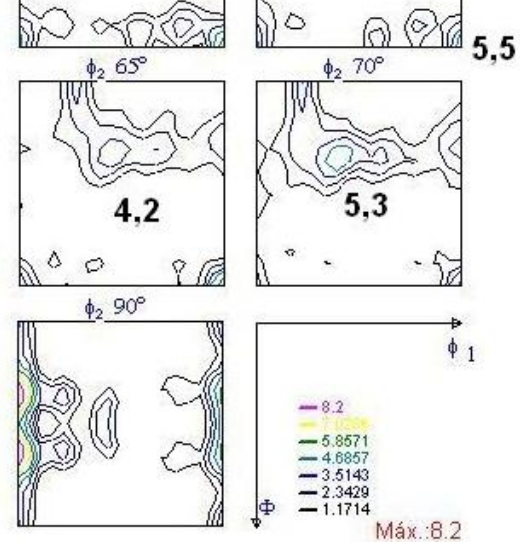

Figura 4.24 - Figuras de pólo (111), (200), (220) e (311) (a) e FDO no centro da amostra laminada com redução de $70 \%$ em área da chapa produzida pelo processo $D C$ da liga AA4006 (b). 
Fibra $\{100\}$

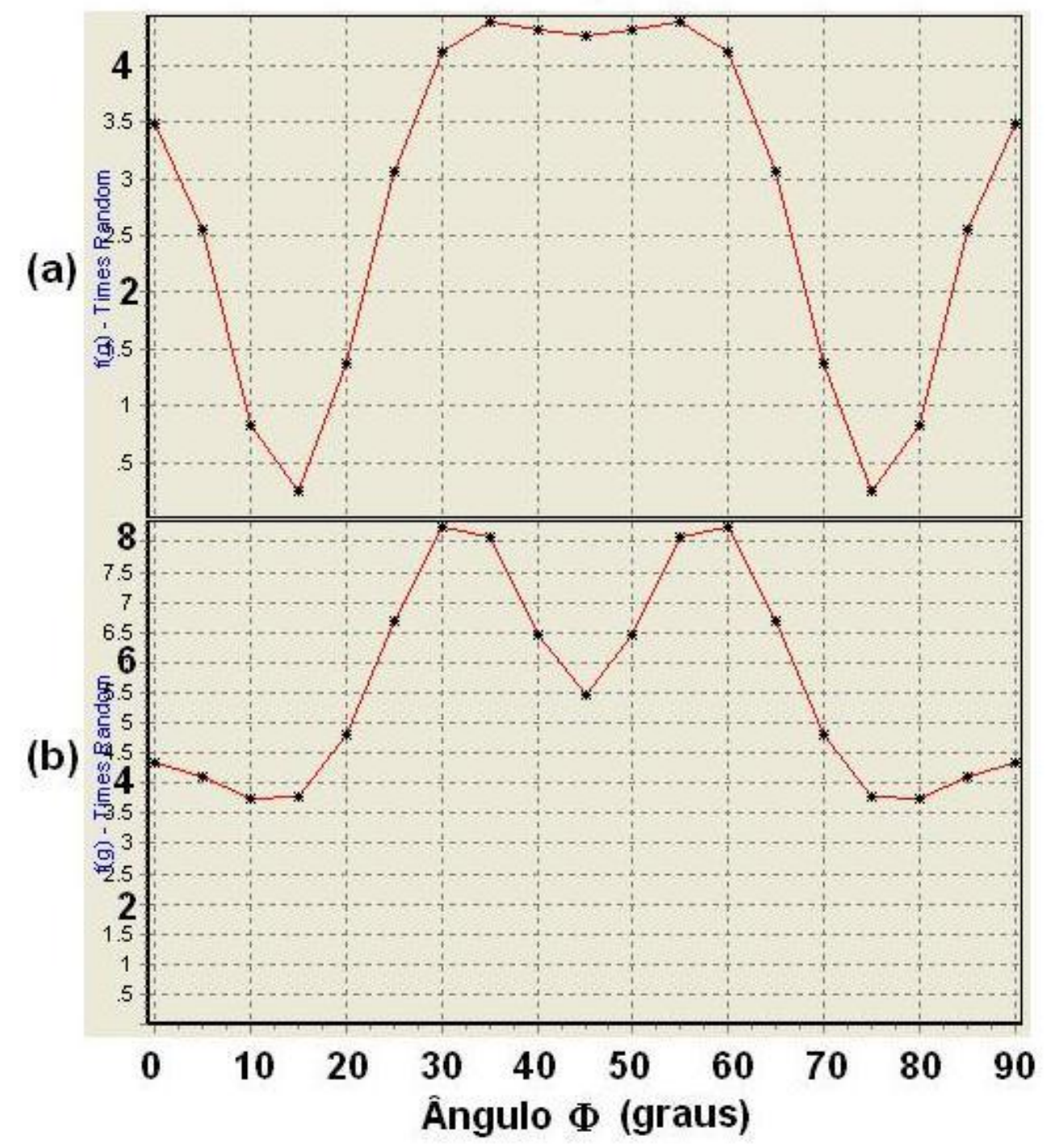

Figura 4.25 - Fibra $\{100\}$ na superfície (a) e no centro (b) da amostra laminada com redução de $70 \%$ em área da chapa produzida pelo processo $D C$ da liga AA4006.

Durante a obtenção e processamento da chapa produzida no processo $D C$ os fenômenos de recuperação e recristalização dinâmica acontecem no decorrer da laminação a quente, como conseqüência, as amostras desta chapa no estado 'como recebido' na superfície e no centro apresentaram as componentes cubo, típica de recristalização, e cubo rodado, com intensidades consideráveis, bem como ausência da fibra $\beta$ (componentes cobre, S e latão) (Figura 4.26). Nesta amostra, devido à laminação a frio, houve $o$ aparecimento da fibra $\beta$ (com maior intensidade na superfície que no centro) e a diminuição das intensidades das componentes cubo e cubo rodado. A componente cubo rodado não apareceu no centro, já que a mesma 
ocorre comumente próximo à superfície (Figura 4.26). Na Figura 4.26a pode ser visto que a componente cubo rodado apareceu com menor intensidade na amostra laminada a frio do que na amostra no estado recebido. Era de se esperar que essa componente aparecesse com maior intensidade devido ao adicional atrito entre os cilindros de laminação e a superfície da amostra na laminação a frio. Assim, devido ao efeito fantasma (ghost peaks) (RAABE, 1995), que pode levar a falsas variações nas intensidades das componentes. Vale lembrar que as correções dos picos fantasmas (ghost errors) não foram corrigidas como tem sido considerado por outros autores (LIU; ZHAI; MORRIS, 2003).

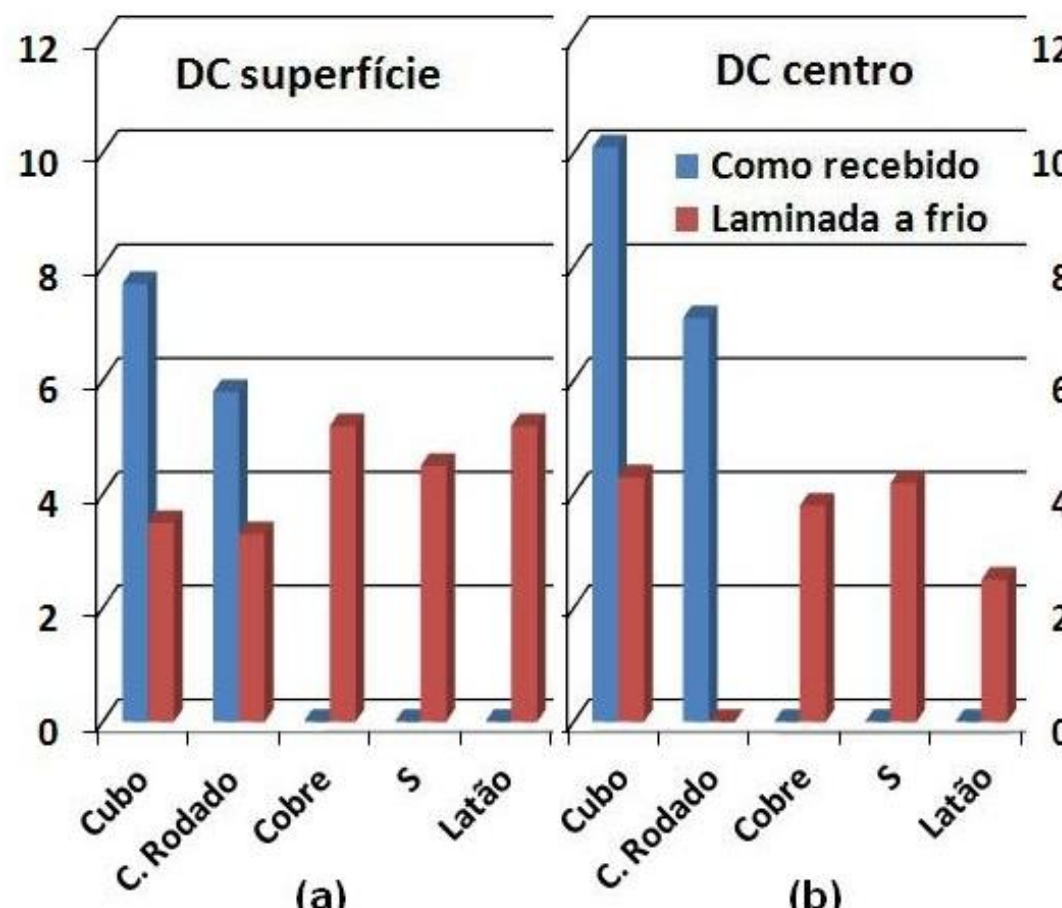

(a) (b)

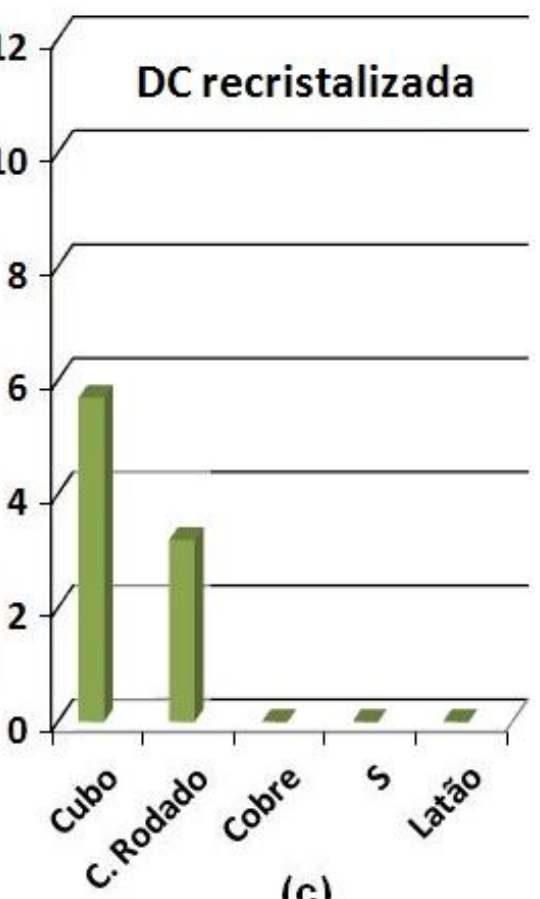

(c)

Figura 4.26 - Evolução da textura em amostras das chapas $D C$ analisadas (a) na região superficial (no estado como recebido e laminado a frio com $70 \%$ de redução em área), (b) na região central (no estado como recebido e laminado a frio com $70 \%$ de redução em área) e (c) recristalizada.

$\mathrm{Na}$ Figura 4.27 pode ser visto que a superfície da amostra da chapa produzida no processo TRC no estado 'como recebido' apresentou as componentes de textura cubo e cubo rodado com as intensidades maiores que nas demais amostras, e após a laminação a frio, a intensidade da componente de textura de cisalhamento (cubo rodado) aumentou, devido ao atrito dos cilindros com a 
superfície da chapa, ou da amostra laminada a frio, como já discutido. No centro da chapa produzida no processo TRC a intensidade da fibra $\beta$ (típica de chapas laminadas) manteve quase a mesma, havendo-se o aumento da intensidade da componente latão e ausência das componentes de textura cubo e cubo rodado após a laminação a frio com $70 \%$ de redução em área. Neste contexto, percebe-se que a fibra $\beta$ se intensifica após a laminação a frio nas duas chapas.

A textura de chapas do alumínio de pureza comercial AA1050 e da liga Al-MnFe-Si AA3003 foi estudada, e após a recristalização de amostras laminadas a frio, foi visto a diminuição da intensidade da fibra $\beta$, evidenciando que em chapas de Al laminadas a fibra $\beta$ aparece com uma intensidade considerável (LÖW, 2000).

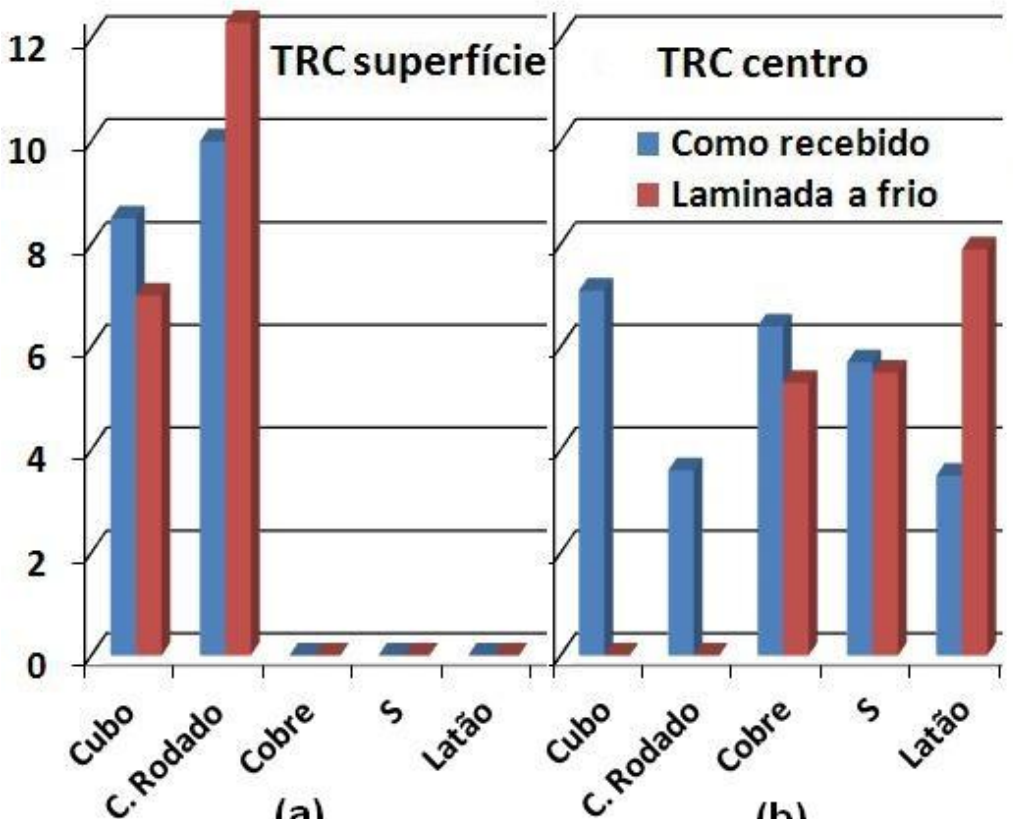

(a)

(b)

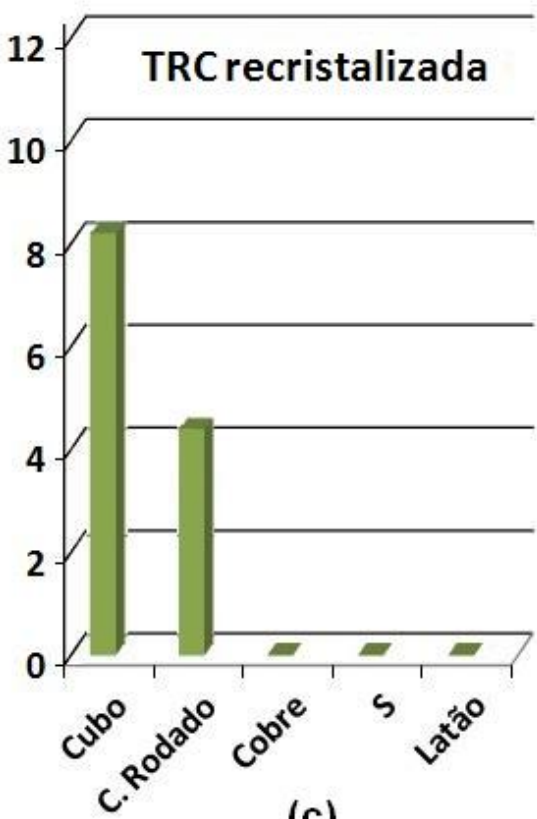

(c)

Figura 4.27 - Evolução da textura das amostras das chapas $T R C$ analisadas (a) na região superficial (no estado como recebido e laminado a frio com 70\% de redução em área), (b) na região central (no estado como recebido e laminado a frio com $70 \%$ de redução em área) e (c) recristalizada.

A textura cristalográfica presente numa chapa metálica antes da realização de um teste de estampagem profunda, por exemplo, deve ser desenvolvida, utilizandose critérios de qualidade industrial, como o orelhamento, medido através dos perfis de profundidade de um copo estampado. Assim, diferentes estiramentos radiais em diferentes direções do disco de estampagem podem acontecer após o ensaio, e 
conseqüentemente, orelhas situadas em regiões de $0^{\circ} / 90^{\circ}$ (em relação à direção de laminação) são vistas (no corpo de prova estampado) em ligas de alumínio recristalizadas, ou nas posições de 0\%/45 (em relação à direção de laminação) em chapas laminadas a frio. Nestes casos as texturas com orelhas em $0 \% / 90^{\circ}$ a textura cubo aparece e com orelhas em 0\%/45 a fibra $\beta$ aparece. Nos dois casos os valores dos parâmetros $R$ e $\Delta R$ não estão otimizados, ou seja, a diminuição de $\Delta R$ e o aumento de $\mathrm{R}$ contribuem para o melhoramento da estampagem quando a combinação das texturas cubo e fibra $\beta$ ocorrem na chapa a ser estampada. Assim, a textura mista com 8 orelhas $0 \% / 45 \% / 90$ pode ser útil para a otimização do processo de estampabilidade de chapas de latas de bebidas, por exemplo, já que há a combinação dessas duas texturas diminuindo $\Delta R$ e aumentando $R$. Além disso, estudos de simulação da plasticidade de policristais podem ser feitos para auxiliar na melhor compreensão deste processo de orelhamento (DOHERTY, 1997; ENGLER; HIRSCH, 2007).

A amostra da chapa obtida pelo método tradicional de produção de chapas $(D C)$ apresentou, após a laminação a frio, a componente cubo e a fibra $\beta$ tanto na superfície quanto no centro, como pode ser visto na Figura 4.26, havendo também o aparecimento da fibra $\{100\}$. Por outro lado, a amostra da chapa obtida pelo processo TRC apresentou apenas a fibra $\beta$, na região central, e apenas as componentes cubo e cubo rodado, na superfície (Figura 4.27), possivelmente devido à presença de grãos dendríticos em sua microestrutura, já que a chapa desta amostra não foi submetida à etapa de laminação a quente para 'quebrar' a microestrutura dendrítica durante o processo de produção.

Nas Figuras 4.28 e 4.29 pode ser visto que as amostras laminadas a frio das duas chapas produzidas no processo $T R C$ e no $D C$, e, posteriormente, recozidas a 400 C por uma hora (após o amolecimento máximo - ver Figura 4.18) apresentaram, principalmente, uma textura com as componentes cubo e cubo rodado, com a ocorrência também de diversas outras componentes, indicando-se a presença de grãos distribuídos, relativamente, de forma aleatória, principalmente na chapa produzida no processo $D C$. Neste contexto, percebe-se que a fibra $\beta$ desapareceu após a laminação a frio nas duas amostras recristalizadas de ambas as chapas (Figuras 4.26 e 4.27 ). 


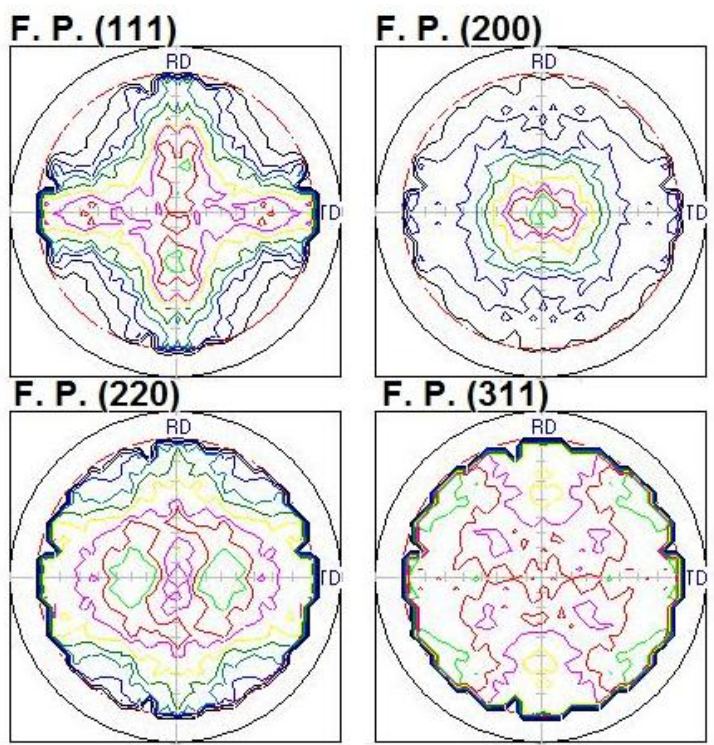

(a)
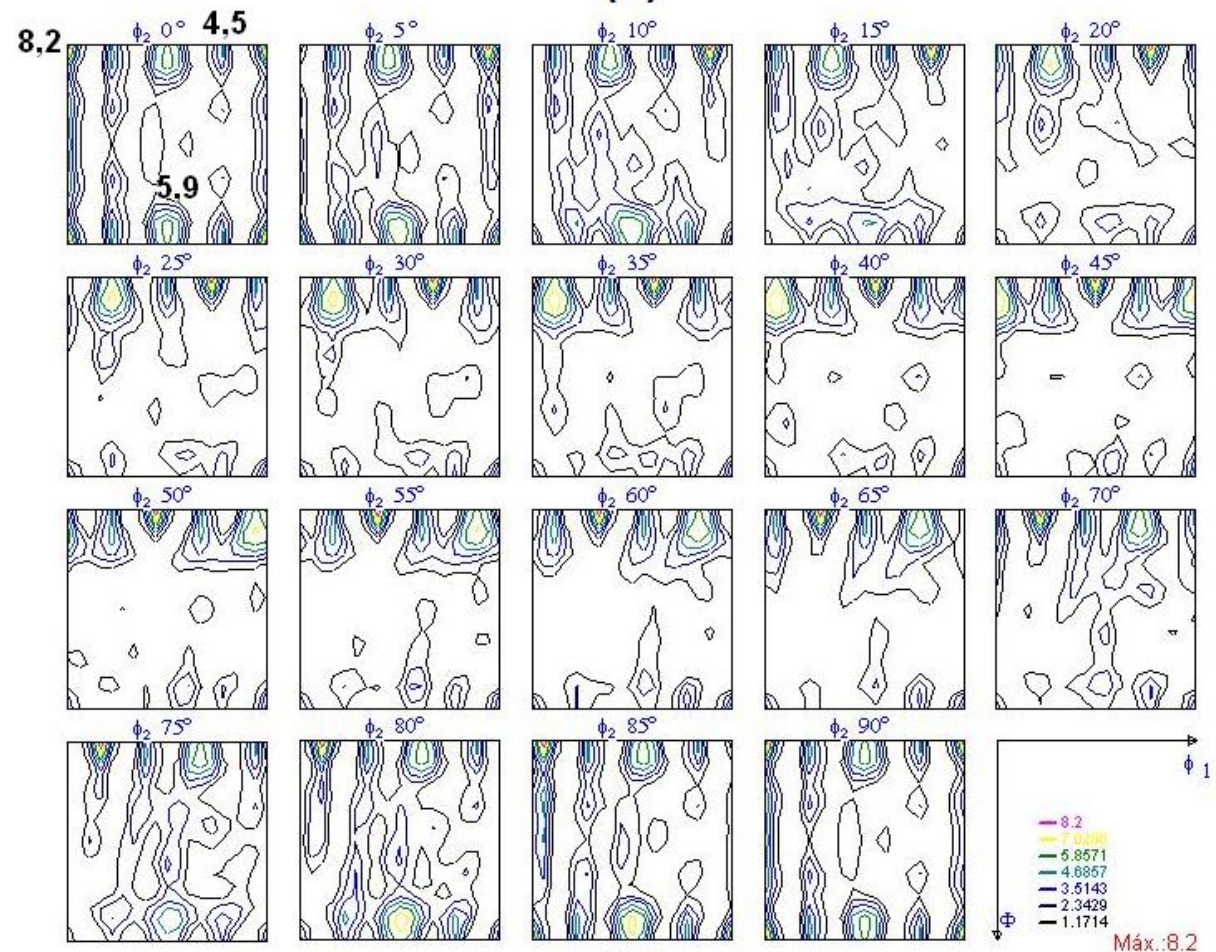

(b)

Figura 4.28 - Figuras de pólo (111), (200), (220) e (311) (a) e FDO da amostra laminada (com redução de $70 \%$ em área) e recozida da chapa produzida pelo processo TRC da liga AA4006 (b). 
F.P. (111)

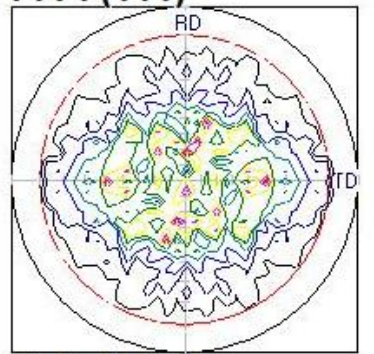

F.P. (220)

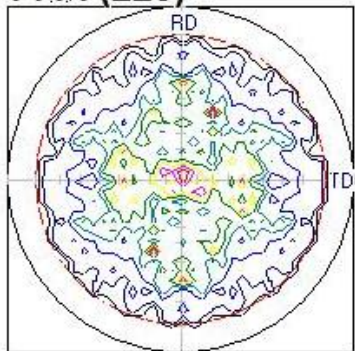

F: P. (200)

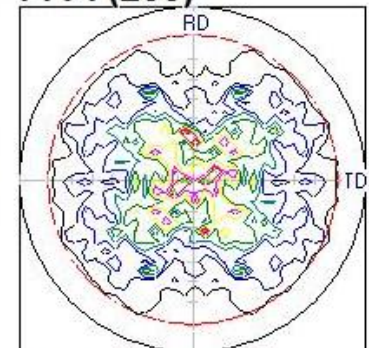

F.P. (311)

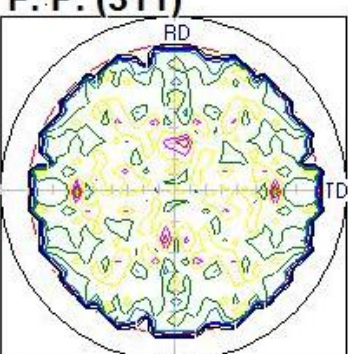

(a)
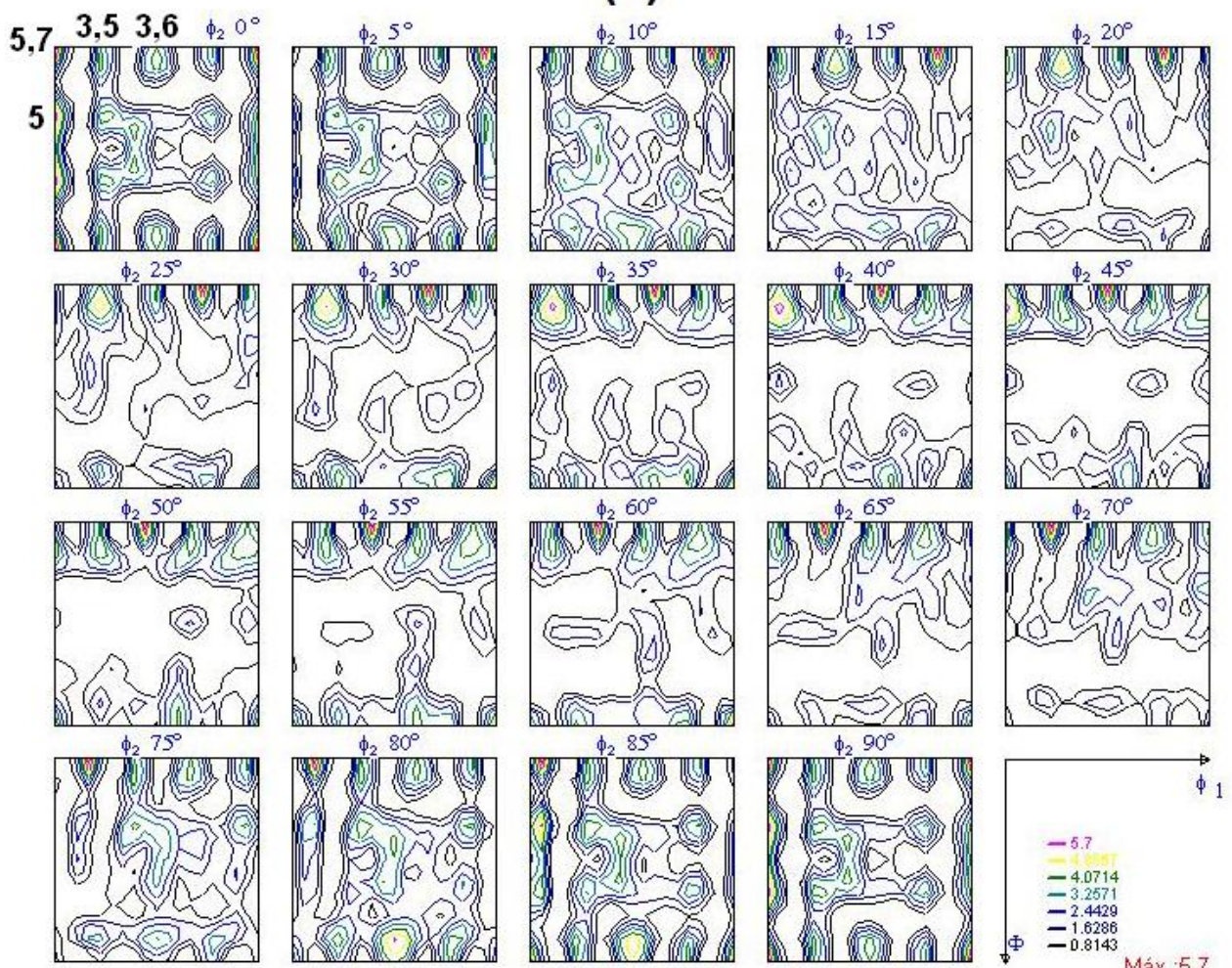

(b)

Figura 4.29 - Figuras de pólo (111), (200), (220) e (311) (a) e FDO da amostra laminada (com redução de $70 \%$ em área) e recozida da chapa produzida pelo processo $D C$ da liga AA4006 (b).

Em trabalhos de outros autores envolvendo estudos sobre a textura de recristalização em ligas de alumínio deformadas a frio, a nucleação para o inicio da recristalização estimulada por partículas foi analisada nas ligas AA1145 (alumínio de 
pureza comercial), AA3103 e Al-1,8\%Cu. Nestas ligas foi observada uma textura de recristalização com uma grande fração de grãos orientados ao acaso, devido à nucleação estimulada por partícula, pois a deformação acentuada destes materiais induz à formação de grandes diferenças nos ângulos de desorientação (heterogeneidades) na subestrutura ao redor da partícula (ENGLER; VATNE; NES,1996; ENGLER, 1997).

Em outros trabalhos, chapas de ligas da série AA6xxx foram estudadas, e constatou-se que a forma como a precipitação das partículas acontecem, o tamanho e o grau de dispersão das partículas influenciam nas texturas de recristalização e na nucleação estimulada por partículas. Deste modo, somente partículas com tamanho acima de $\eta^{*}$ podem iniciar a nucleação estimulada por partículas, conforme a equação: $\eta^{*}=2 \gamma_{G B} /\left(p_{D}-p_{Z}\right)$, onde $\gamma_{G B}$ é a energia específica do contorno de grão, $p_{D}$ é a força motriz para a recristalização e $p_{z}$ a força de arraste (de Zener) devido à partícula. Neste contexto, partículas finamente dispersas em uma chapa fazem com esta chapa adquira a textura cubo, que se sobressai à textura estimulada por partícula, a qual predomina no material com partículas altamente dispersas (ENGLER; HIRSCH, 2002). Neste contexto, as amostras (da liga AA4006) laminadas a frio e recozidas também apresentaram este comportamento, pois, na 'chapa TRC' os precipitados estão mais finamente dispersos do que na 'chapa $D C$ ' (Figura 4.17), assim, nesta primeira houve a predominância da componente cubo (Figura 4.28), enquanto na outra houve maior predominância de uma textura com grãos orientados ao acaso, como visto na amostra da 'chapa $D C$ ' na Figura 4.29.

Nas Figuras 4.28 e 4.29 pode ser visto também que uma textura com variadas componentes ocorrem nas duas chapas produzidas pelos dois processos TRC e DC, indicando que os grãos destas amostras, laminadas a frio e recozidas, possuem grãos orientados ao acaso, como visto nos estudos de nucleação estimulada por partículas (ENGLER; VATNE; NES,1996; ENGLER, 1997). Vale lembrar que nas regiões de heterogeneidades (bandas de deformação e bandas de cisalhamento) com grandes diferenças nos ângulos de desorientação (formadas na deformação plástica) estão os núcleos em potencial para a ocorrência da nucleação (KAMIJO et al, 1993), e conseqüentemente, há a migração dos contornos (destes núcleos) de

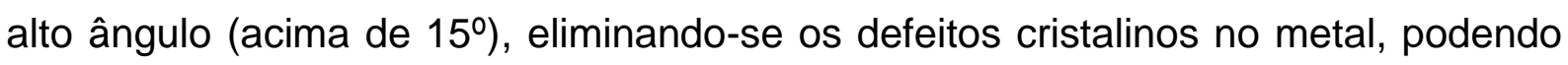
gerar, portanto, grãos orientados com relativa aleatoriedade. As duas amostras ( TRC e $D C$ ) laminadas a frio com posterior recozimento foram submetidas também à 
análise por difração de elétrons retroespalhados $E B S D$, a fim de analisar a mesotextura e a microtextura das amostras das duas tiras metálicas analisadas por raios $X$ (Figuras 4.28 e 4.29), como será abordado a seguir.

\subsection{Obtenção das texturas cristalográficas por meio da técnica de difração de elétrons retroespalhados EBSD em amostras recristalizadas das chapas laminadas}

A técnica de difração de elétrons retroespalhados (Electron back scatter diffraction - EBSD) é muito importante para complementar a análise da orientação cristalográfica dos grãos no metal, já que apenas a análise por raios $X$ não é suficiente para a completa avaliação de um grão em particular, ou de quantidades bem pequenas de grãos, pois a técnica de difração por raios $X$ avalia a textura do material, de forma macroscópica (macrotextura). Em contrapartida, pequenas quantidades de grãos em conjunto, onde cada grão tem sua orientação específica, podem ser conhecidas, e desta forma, a microtextura é obtida. Além disso, a textura entre os grãos ou a diferença de orientação na região de encontro (linha de contorno ao redor dos grãos no plano de análise) dos grãos entre si, ou a geometria do contorno de grão (mesotextura), pode ser determinada (PADILHA, 1999; PINTO; LOPES, 2001; SOUZA et al, 2011).

As Figuras 4.30 e 4.31 apresentam os mapas das orientações cristalográficas dos grãos de áreas superficiais (polidas eletroliticamente com $30 \%$ de $\mathrm{HNO}_{3}$ e $70 \%$ de etanol) das microestruturas das amostras laminadas (com redução de $70 \%$ em área) e recozidas (a $400^{\circ} \mathrm{C}$ por uma hora) das chapas produzidas pelos processos $T R C$ e $D C$, respectivamente. Nestas imagens pode-se observar que os grãos apresentam orientações cristalográficas aleatórias, como indica a variedade de cores em cada grão, referentes às diferentes orientações cristalográficas, relativas às regiões codificadas no mapa da figura de pólo inversa. A presença de precipitados, principalmente nas regiões dos contornos de grão, levou ao aparecimento de pequenos círculos de contornos ('contornos fantasmas') de alto ângulo, nestas regiões e em algumas partes no interior de alguns grãos (Figuras 4.30 e 4.31$)$. 


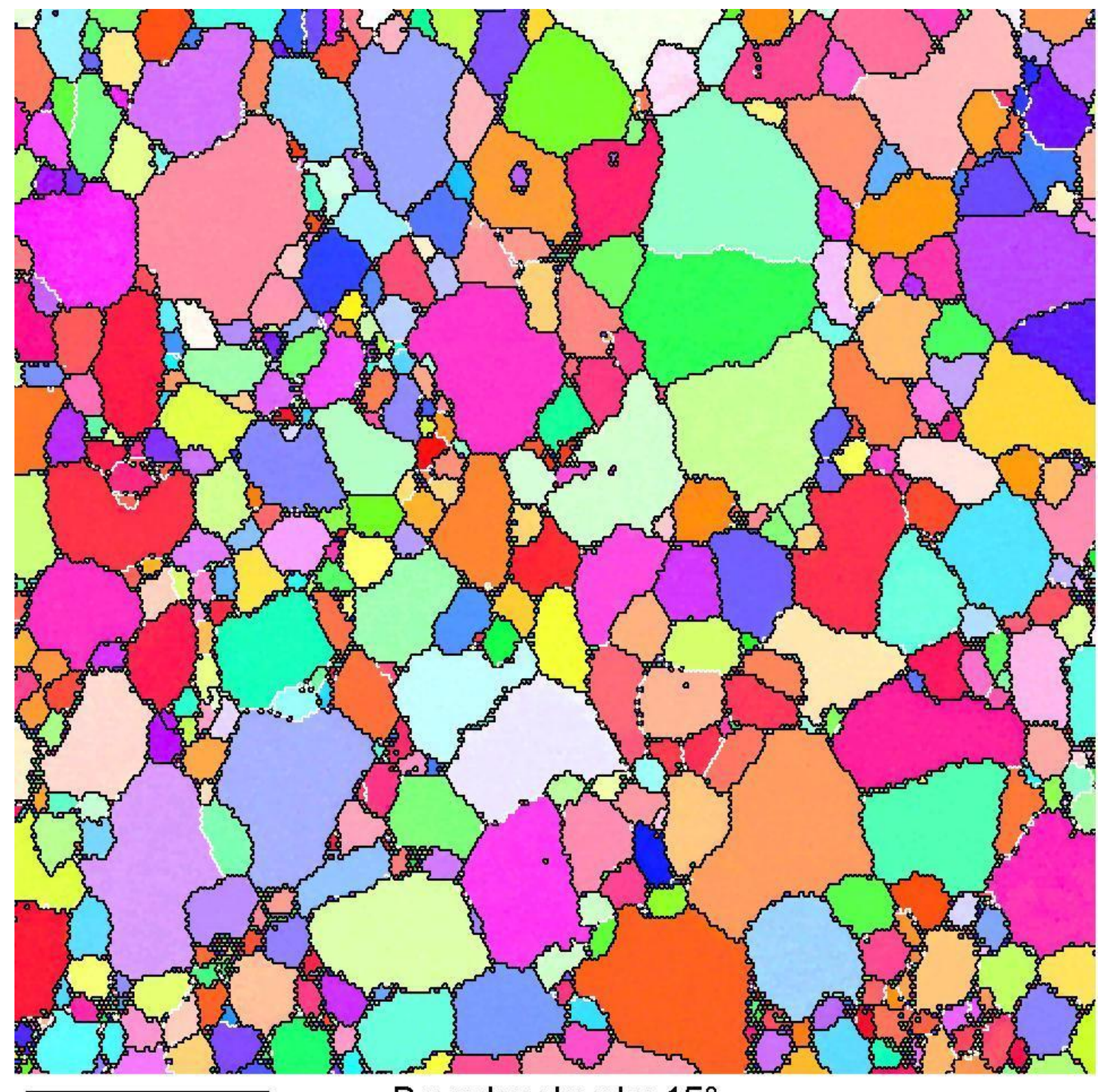

Boundary levels: $15^{\circ}$

$25.00 \mu \mathrm{m}=50$ steps IPF [001]

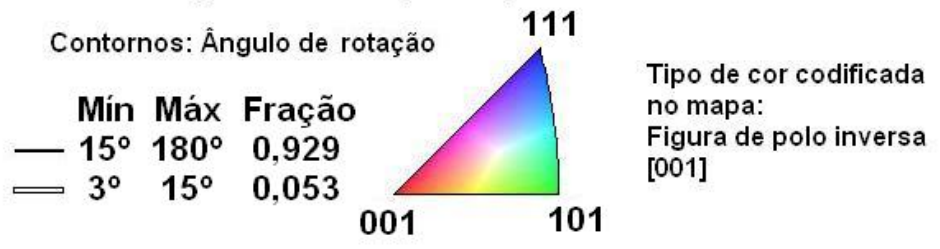

Figura 4.30 - Imagem das orientações cristalográficas dos grãos da microestrutura da amostra laminada (com redução de $70 \%$ em área) e recozida da chapa produzida pelo processo $T R C$ da liga AA4006. 


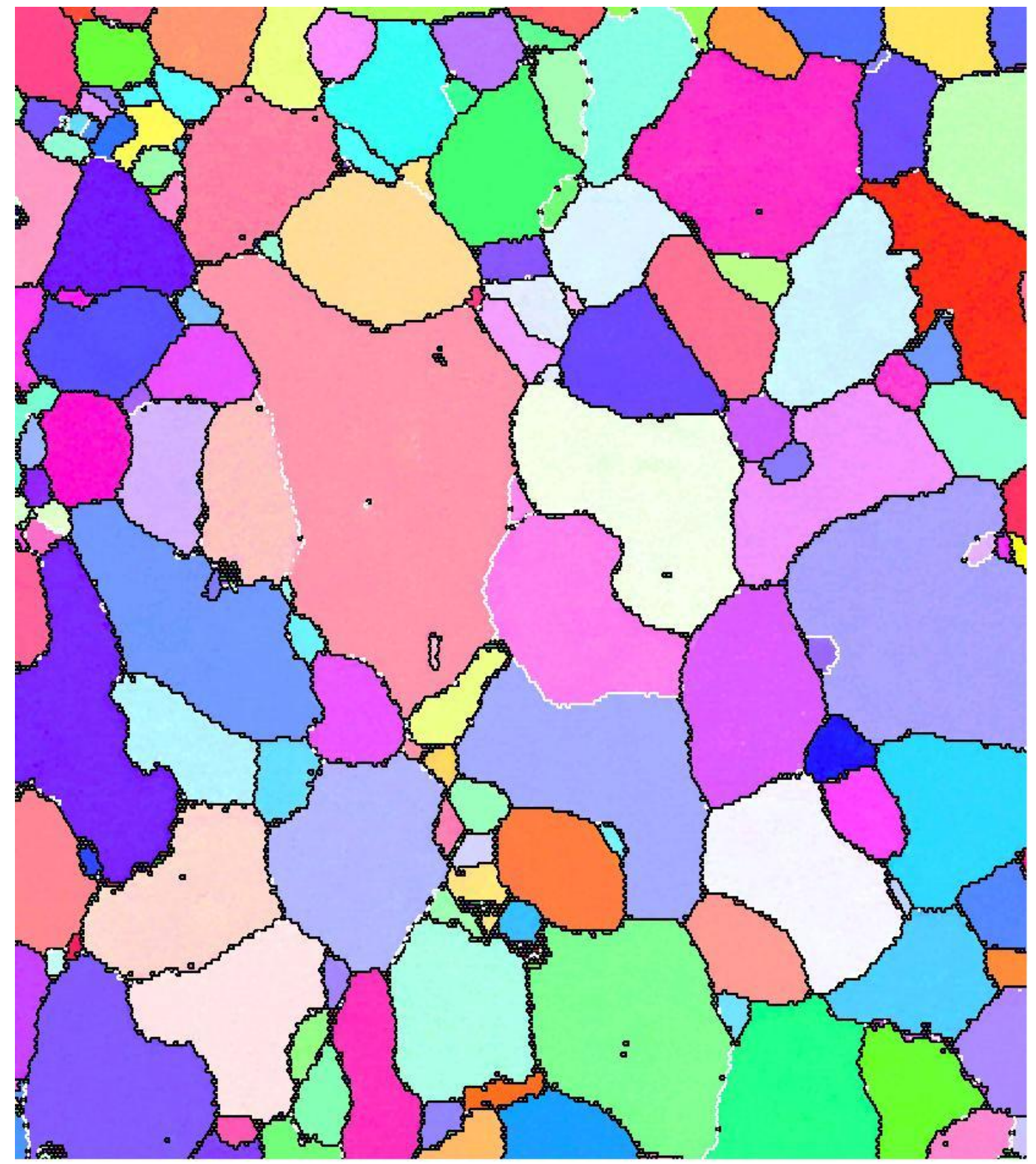

\section{Boundary levels: $15^{\circ}$}

$25.00 \mu \mathrm{m}=50$ steps IPF [001]

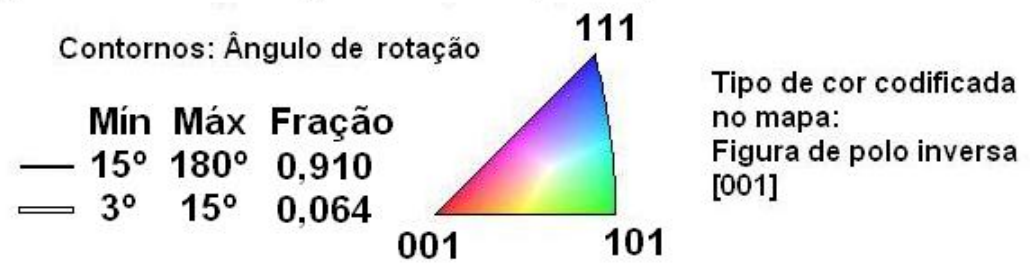

Figura 4.31 - Imagem das orientações cristalográficas dos grãos da microestrutura da amostra laminada (com redução de $70 \%$ em área) e recozida da chapa produzida pelo processo $D C$ da liga AA4006. 
Portanto, estes resultados de EBSD reforçam a idéia de que há a presença de boa parte dos grãos orientados aleatoriamente nas duas amostras das duas chapas como visto nos resultados de textura obtidos por difração de raios $\mathrm{X}$, anteriormente, (Figuras 4.28 e 4.29), ou seja, uma textura ao acaso surgiu nas amostras analisadas, após o recozimento em $400 \stackrel{\circ}{\mathrm{C}}$ durante uma hora.

As Figuras 4.30 e 4.31 apresentam também as frações dos contornos de grãos presentes na área mapeada utilizando $E B S D$. Nestas figuras pode visto que a quantidade de contornos de alto ângulo $\left(>15^{\circ}\right)$ é bem maior que a quantidade de contornos de baixo ângulo $\left(<15^{\circ}\right)$, indicando que nas amostras há a presença de pouquíssimos subgrãos, já que as amostras foram recristalizadas.

Nas Figuras 4.32 e 4.33 podem ser vistas as figuras de pólo (111), (200), (220) e (311), e nas Figuras 4.34 e 4.35, as FDO's também podem ser vistas nas amostras laminadas com redução de $70 \%$ em área e, posteriormente, recozidas para as duas chapas produzidas pelos dois processos TRC e DC da liga AA4006.
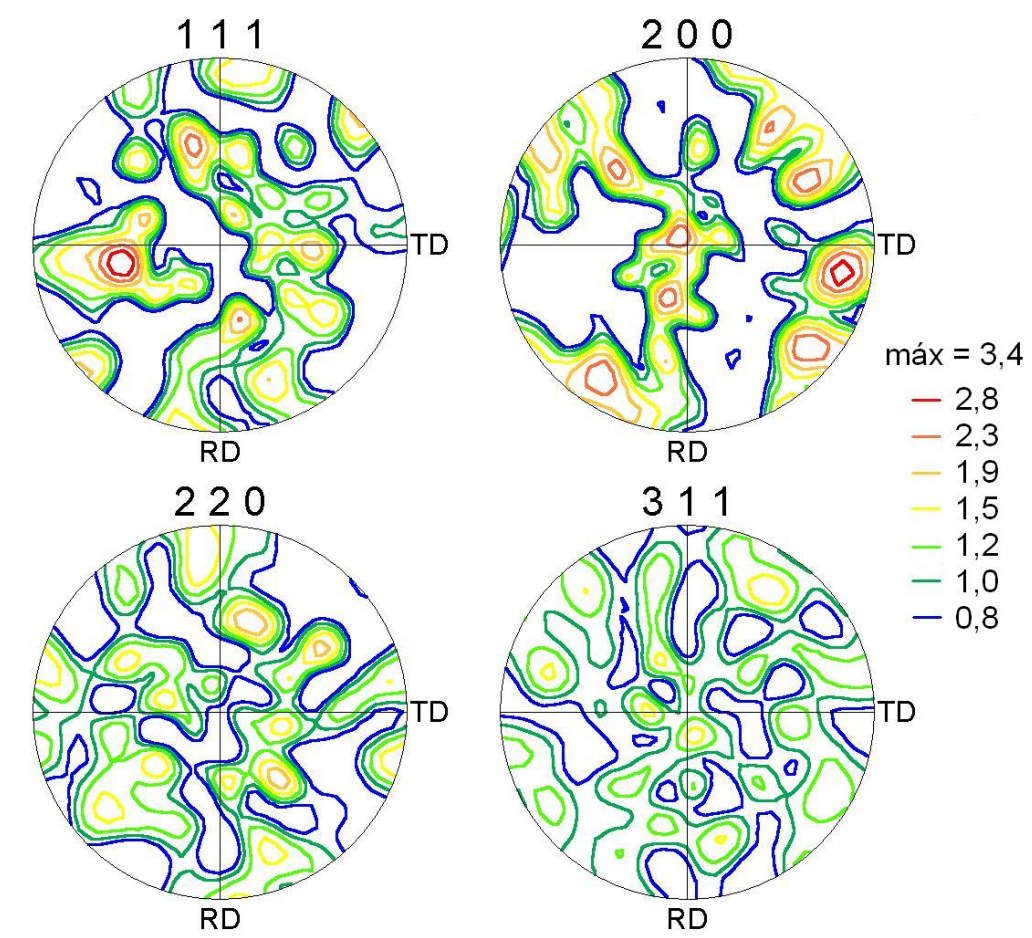

Figura 4.32 - Figuras de pólo (111), (200), (220) e (311) da amostra laminada com redução de $70 \%$ em área e recozida da chapa produzida pelo processo $T R C$ da liga AA4006.

Nas figuras de pólo e nas ODF’s (Figuras 4.32, 4.33, 4.34 e 4.35) percebe-se 
que as regiões de maiores densidades de probabilidade de ocorrência dos pontos relativos às componentes mais comuns encontradas em chapas recristalizadas não aparecem com intensidade significativa, como a componente de textura cubo, por exemplo, indicando que uma textura de diferentes componentes está presente nas amostras recozidas, como reportado em outro trabalho (SOUZA et al, 2011).
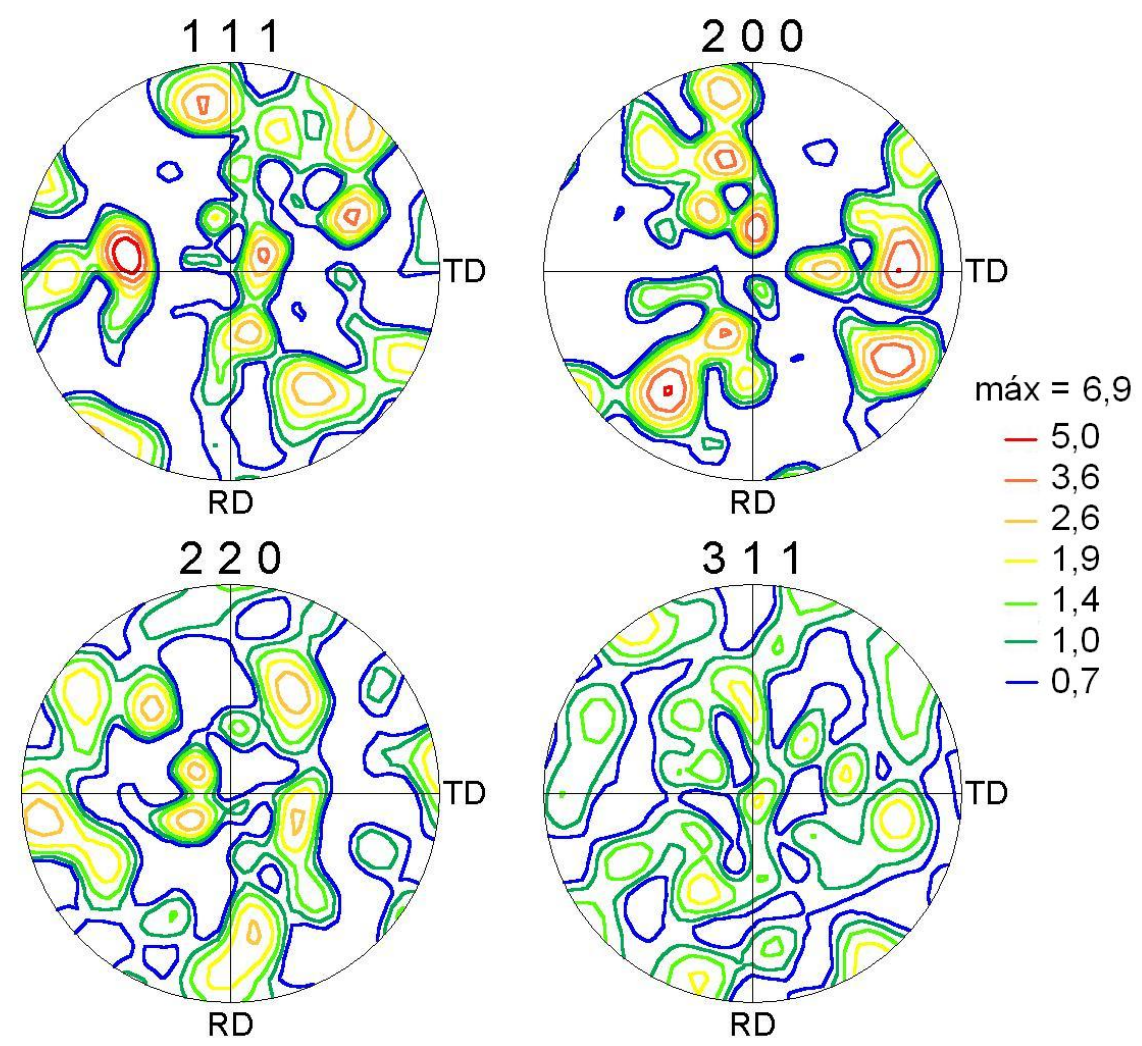

Figura 4.33 - Figuras de pólo (111), (200), (220) e (311) da amostra laminada com redução de $70 \%$ em área e recozida da chapa produzida pelo processo $D C$ da liga AA4006. 

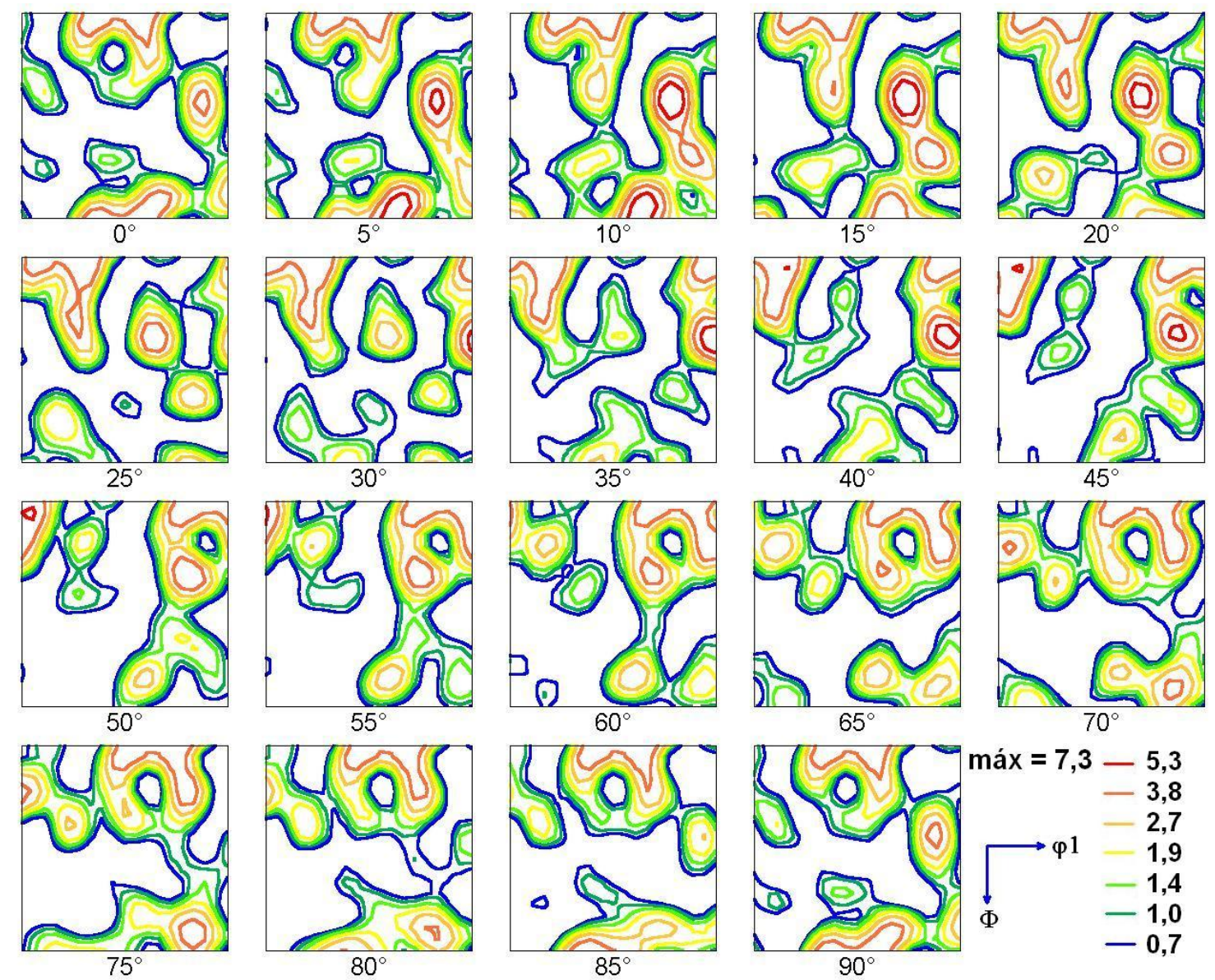

Figura 4.34 - FDO's da amostra laminada com redução de 70\% em área e recozida da chapa produzida pelo processo TRC da liga AA4006. 

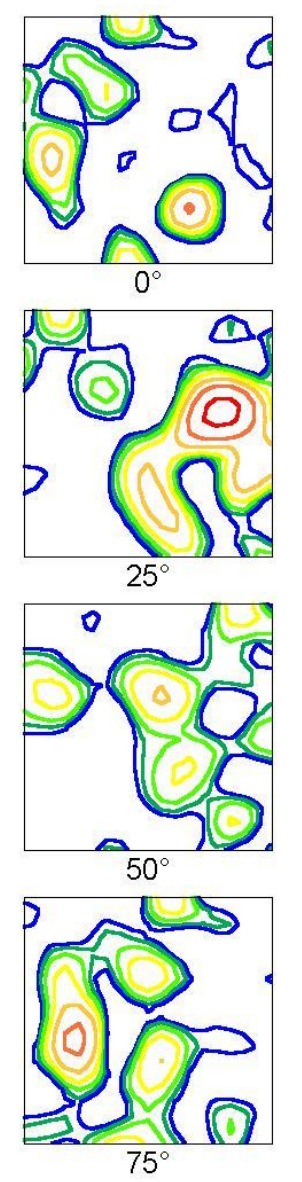
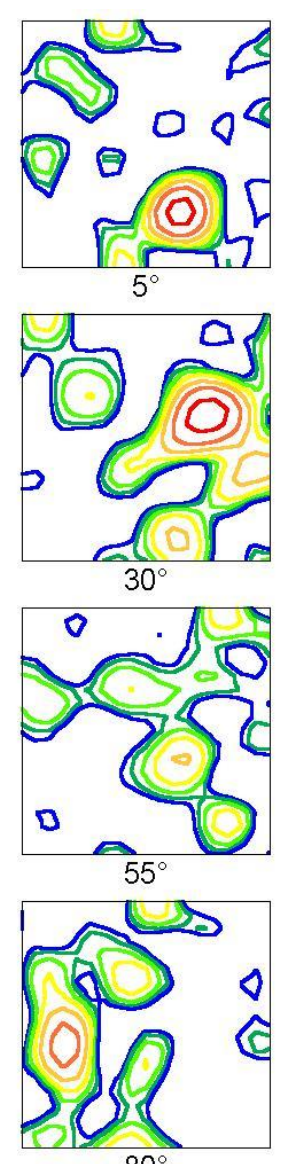

$80^{\circ}$
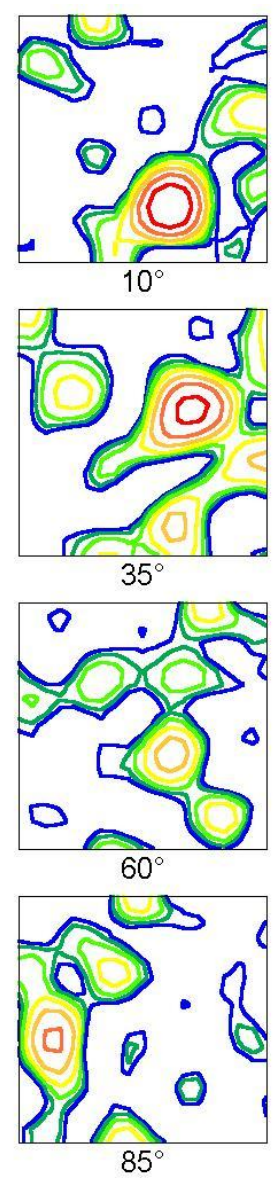
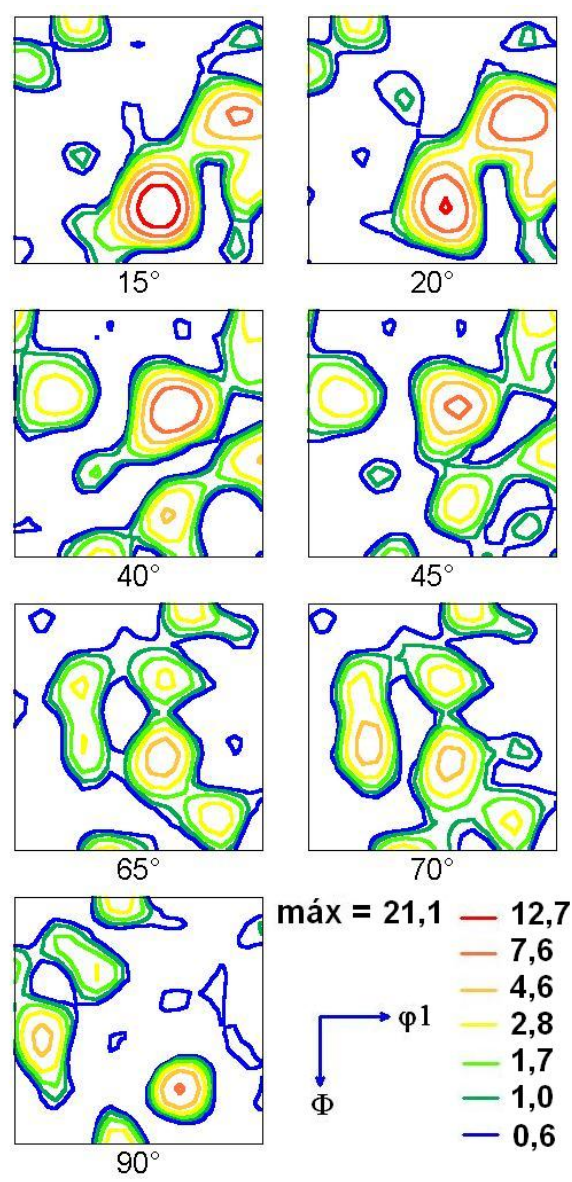

Figura 4.35 - FDO's da amostra laminada com redução de 70\% em área e recozida da chapa produzida pelo processo $D C$ da liga AA4006.

A distribuição das frações das quantidades de ocorrência dos contornos de grão em função da orientação pode ser vista nas Figuras 4.36 e 4.37, para as amostras laminadas com redução de $70 \%$ em área e recozidas (das chapas produzidas pelos processos $T R C$ e $D C$ ). Nos gráficos destas figuras pode ser visto que a maior parte de ocorrência dos ângulos, que apresentam as diferenças de orientação cristalográfica entre os grãos, se encontra acima de $15^{\circ}$, para as duas tiras metálicas laminadas e recozidas, como detectado e discutido nos resultados vistos nas Figuras 4.30 e 4.31. 


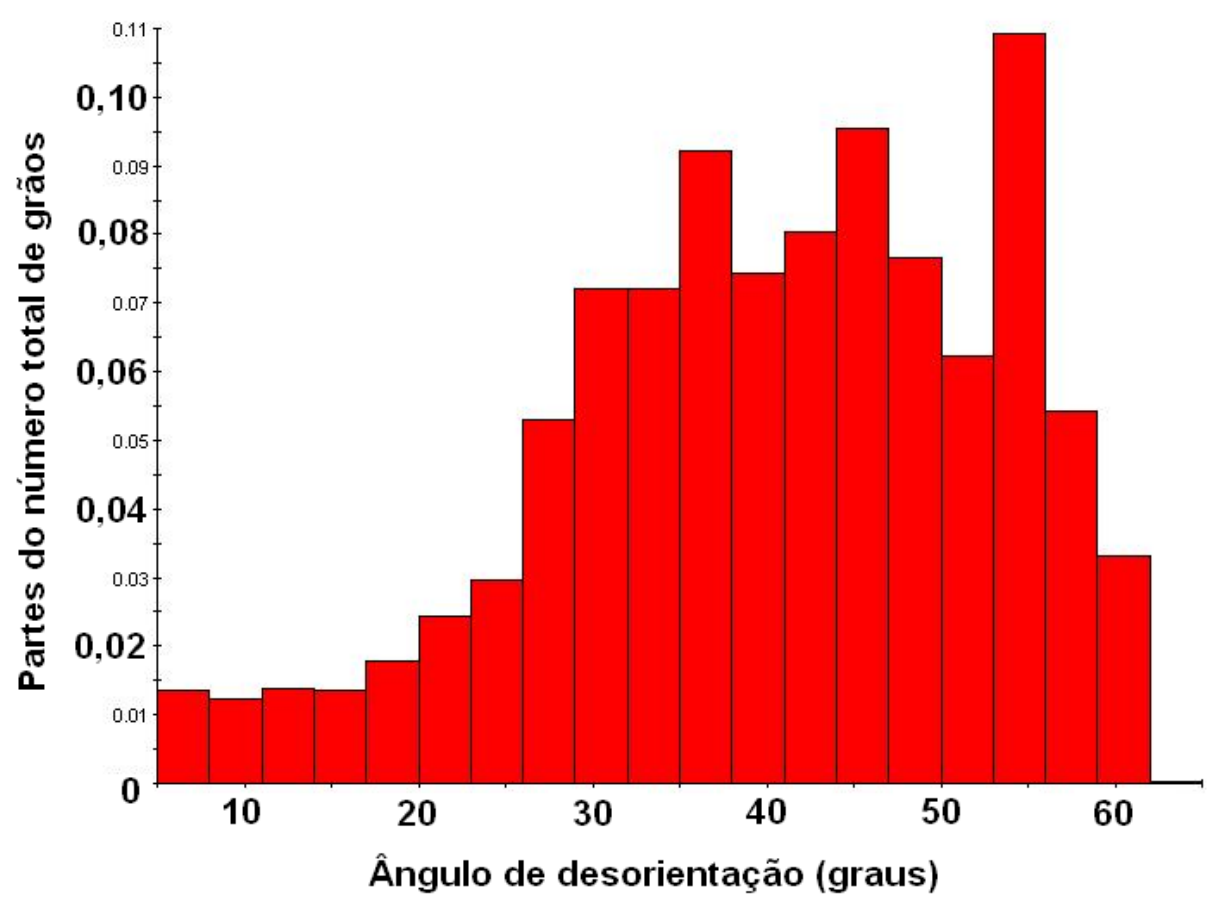

Figura 4.36 - Distribuição das frações de contornos de grão na área mapeada por $E B S D$ em função do ângulo de orientação para a amostra (TRC) laminada com redução de $70 \%$ em área e recozida.

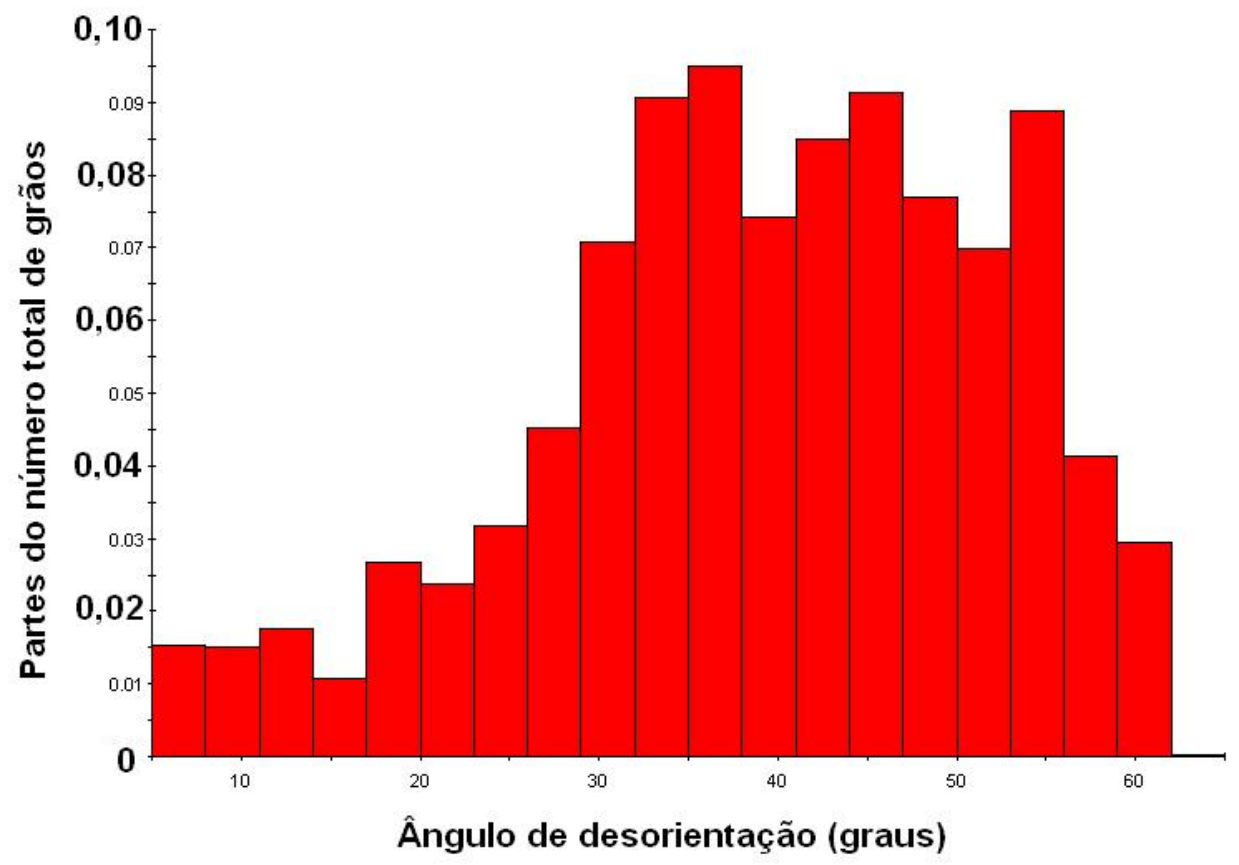

Figura 4.37 - Distribuição das frações de contornos de grão na área mapeada por $E B S D$ em função do ângulo de orientação para a amostra $(D C)$ laminada com redução de $70 \%$ em área e recozida. 
A mesma imagem inicial do mapa, que envolve as orientações dos grãos, obtida da varredura do feixe de elétrons no $E B S D$, pode ser construída por outras formas. O mapa do índice de qualidade (IQ) é representado através de uma escala de cinza, onde pontos brancos se referem ao melhor índice, e pontos pretos se referem ao pior índice. Este mapa pode indicar problemas como distorções na rede do material, oscilações da corrente do feixe, entre outros.

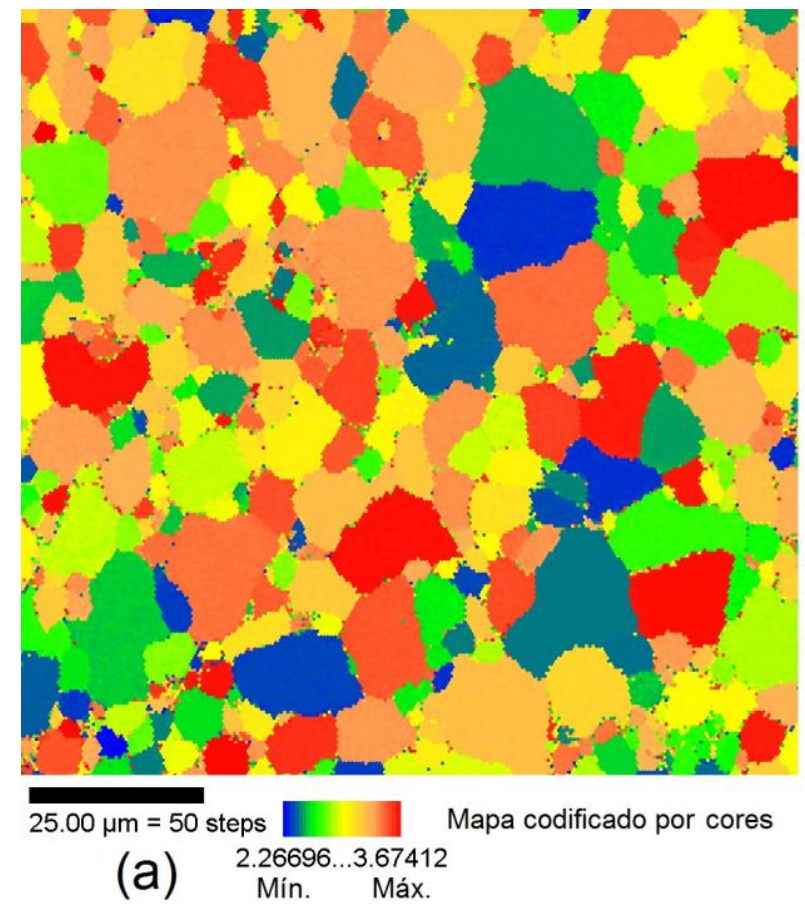

(a) $2.26696 \ldots . .3 .67412$

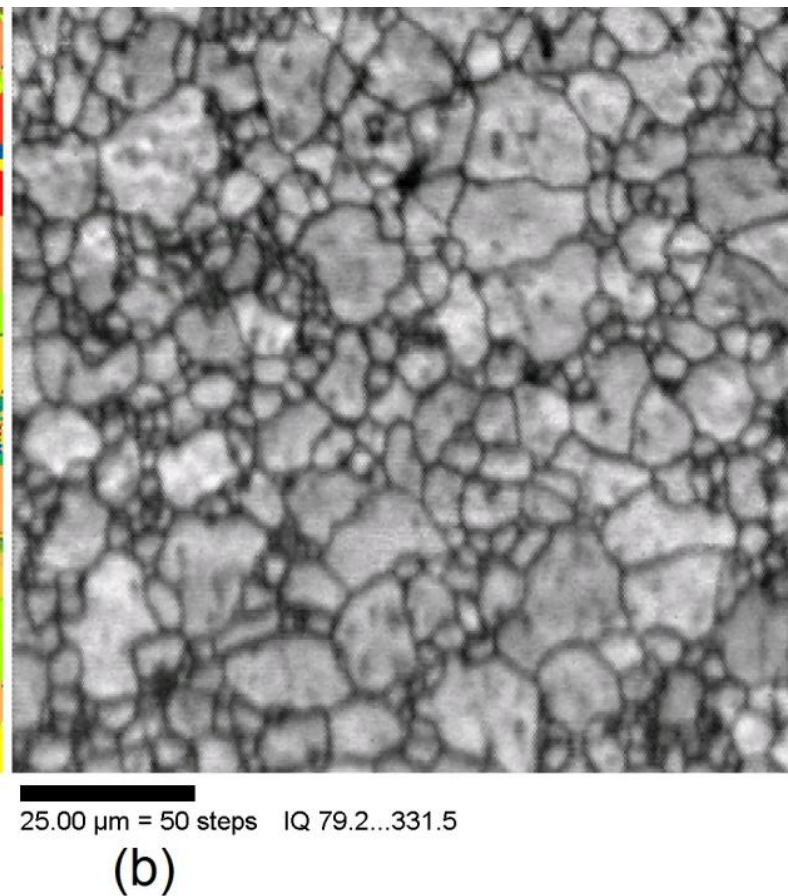

(b)

Figura 4.38 - Mapeamento do fator de Taylor (a) e do índice de qualidade (b) da amostra laminada com redução de $70 \%$ em área e recozida da chapa produzida pelo processo TRC.

O mapa do fator de Taylor avalia a dependência da orientação de determinados grãos com o alinhamento dos sistemas de deslizamento ativos (com mínimo trabalho de deformação plástica) em relação à direção de deformação e dos sistemas pouco ativados (de orientações desfavoráveis para o deslizamento) que necessitam de tensões maiores durante a deformação plástica para serem ativados. Assim, pode-se analisar o quão susceptível está o material policristalino à deformação plástica, pois a movimentação de discordâncias ocorre em planos e direções de empacotamento denso. Para baixos valores no fator de Taylor, estão disponíveis no interior do grão sistemas de deslizamento mais eficientes, necessitando-se mais baixas forças (tensões) de trabalho para deformá-lo, enquanto 
que, para altos valores do fator de Taylor será necessário maior força (KASSNER, 1990; PINTO; LOPES 2001; HOSFORD, 2006; TAYON et al, 2010).

As Figuras 4.38 e 4.39 apresentam o mapa do fator de Taylor e o mapa do índice de qualidade, obtidos na varredura por EBSD, para as amostras (analisadas nas Figuras 4.30 e 4.31), laminadas com redução de $70 \%$ em área e recozidas, das chapas produzidas pelos processos $T R C$ e $D C$, respectivamente.
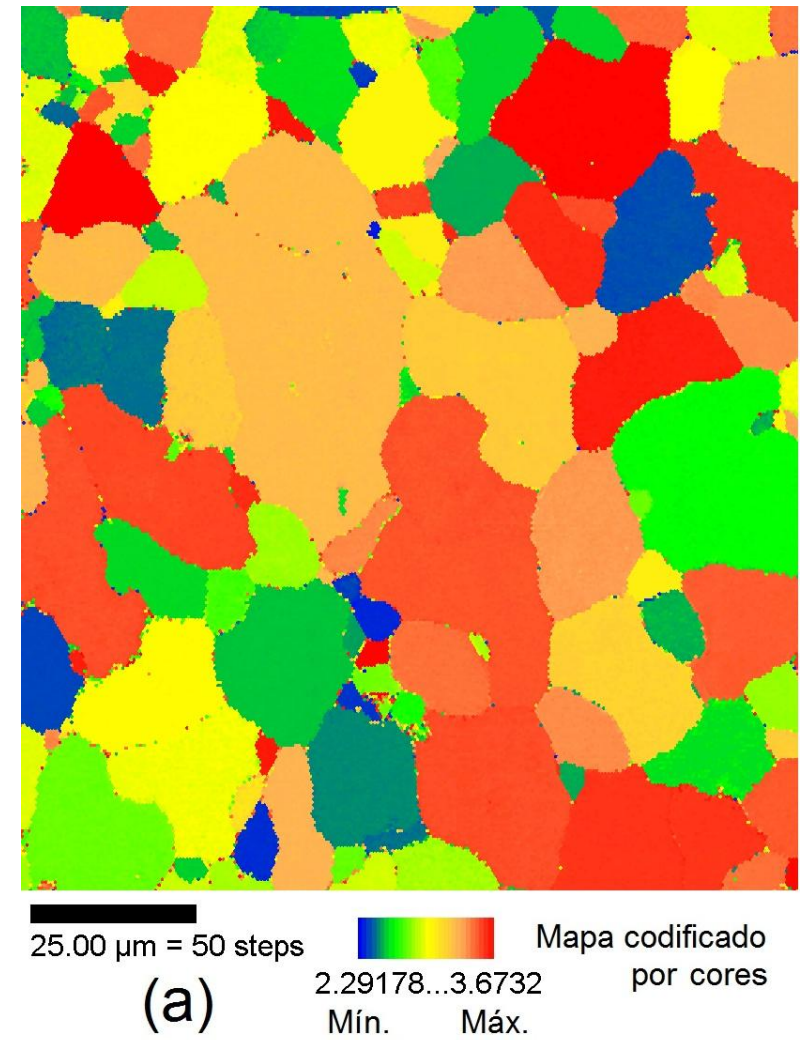

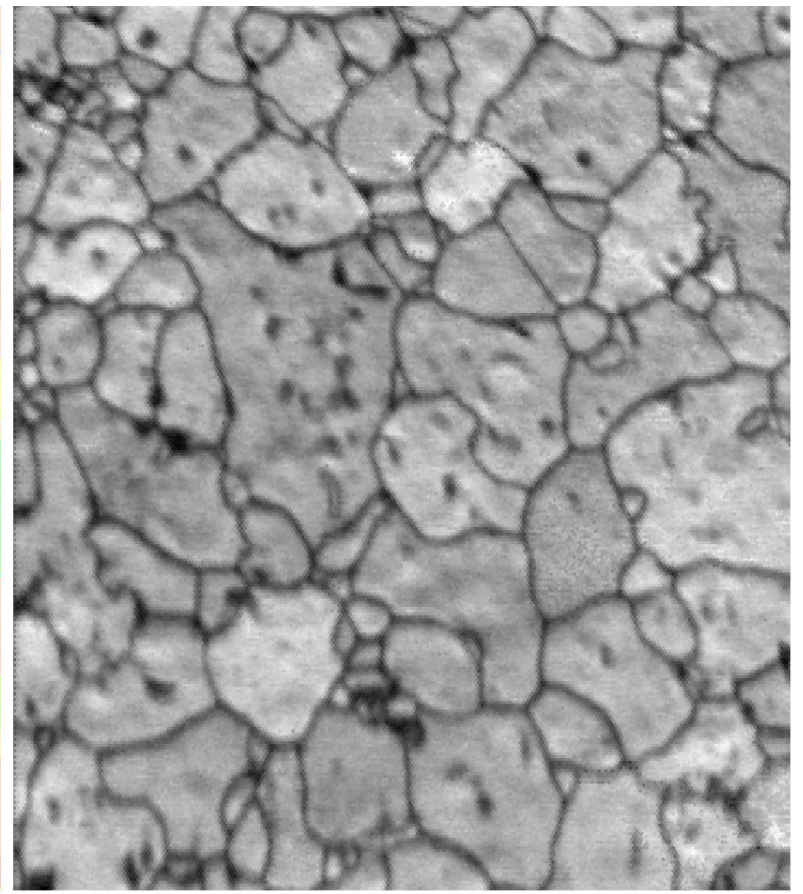

$25.00 \mu \mathrm{m}=50$ steps $\mathrm{IQ} 90.9 \ldots 357$

(b)

Figura 4.39 - Mapeamento do fator de Taylor (a) e do índice de qualidade (b) da amostra laminada com redução de 70\% em área e recozida da chapa produzida pelo processo $D C$.

As cores dos grãos no mapa codificado das orientações específicas de cada grão se encontram em diversas partes no espectro de cores da escala do mapa do fator de Taylor, para ambas amostras (TRC e DC). Assim, nos mapas das Figuras 4.38 e 4.39 pode ser visto que diferentes orientações que estão relacionadas com os sistemas de deslizamento são vistos nos diferentes grãos. Dessa forma, sugere-se que as amostras laminadas e posteriormente recozidas, ou recristalizadas, apresentaram regiões com a combinação dos sistemas de deslizamento mais eficientes e de sistemas de deslizamento menos eficientes (com orientações mais 
favoráveis e menos favoráveis para o deslizamento). Nesse contexto, pode ser sugerido que esta combinação pode comprometer a resistência dessas amostras ( TRC e $D C$ ), caso sejam submetidas ao trabalho mecânico, devido à possibilidade de abertura de microvazios ou microtrincas nestas regiões (encontro de alto e baixo fator de Taylor). Isto pode favorecer a propagação de trincas, já que houve a presença de uma baixa textura para ambas amostras (laminadas seguidas de recristalização) das chapas produzidas pelos processos TRC e DC.

A curva da distribuição de Mackenzie avalia numericamente a relação dos ângulos de orientação, assim, pode-se verificar se a relação de orientação entre os grãos se encontra ao acaso (LIMA, 2005; MACKENZIE, 1958). O gráfico na Figura 4.40a apresenta as freqüências das orientações dos grãos nas duas amostras (TRC e $D C$ ) com suas respectivas linhas de tendência (ajustes). O gráfico da Figura 4.40b indica uma distribuição dos grãos ao acaso, como pode ser visto nas linhas dos ajustes dos resultados das amostras (TRC e DC) (Figura 4.40a), que seguem a distribuição de Mackenzie (Figura 4.40b), indicando que as áreas analisadas por EBSD nas amostras apresentam grãos orientados ao acaso, como já visto.

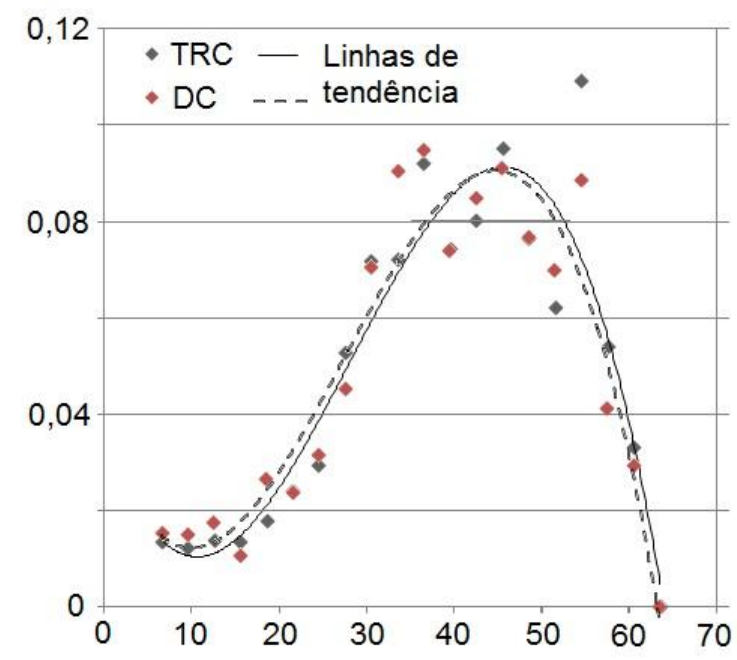

(a) Relação de orientação (graus)

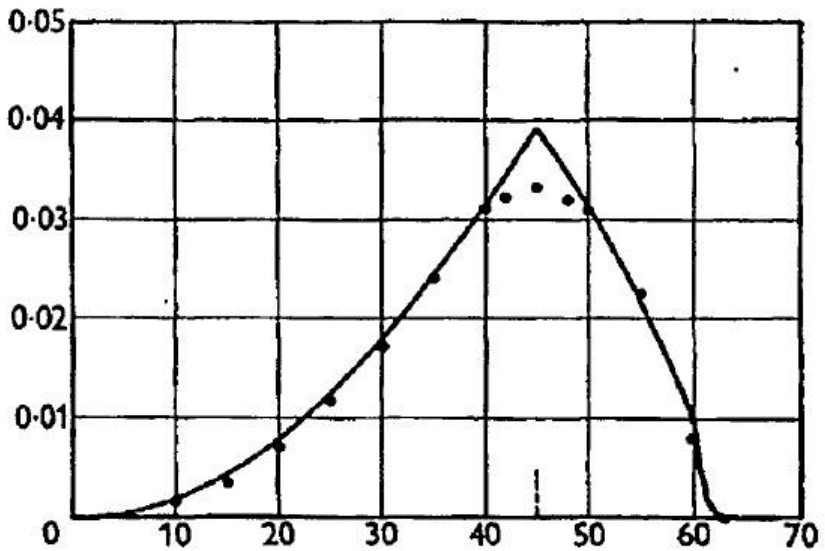

(b) Relação de orientação (graus)

Figura 4.40 - Distribuição das frações de contornos de grão na área mapeada por $E B S D$ em função do ângulo de orientação juntamente com os respectivos ajustes (linhas de tendência) para as amostras (TRC e DC) laminadas com redução de $70 \%$ em área e recozidas (a) e freqüência da relação de orientação para a distribuição ao acaso (Distribuição de Mackenzie) (b) (MACKENZIE, 1958). 
Algumas limitações da técnica de EBSD, em duas dimensões 2D, têm motivado o estudo da caracterização por EBSD, em três e quatro dimensões 3D e $4 D$, onde a técnica mais utilizada atualmente em 3D é a técnica que utiliza um feixe de íon focado, juntamente, com o EBSD. Em estudos sobre recristalização, utilizando medidas em 4D por microscopia 3D de difração de raios-X de alta energia, observou-se que cada núcleo/grão tem sua própria cinética de recristalização, e, a migração do contorno de grão ocorre de forma complexa, bem como núcleos com novas orientações podem ser formados (HANSEN; JUUL JENSEN, 2011).

\subsection{Considerações finais}

Após o estudo das mudanças microestruturais e da textura cristalográfica, bem como dos fenômenos envolvidos na recristalização, resumidamente, convém abordar sobre alguns aspectos que podem estar relacionados a esse estudo.

A predição quantitativa física da evolução microestrutural e as relações entre a microestrutura e propriedades de um material metálico podem ser desenvolvidos. Dessa forma, quando expressões matemáticas analíticas, com aproximações, não podem ser formuladas, e o problema investigado não está acessível a experimentos, há o emprego do modelamento e simulação. Nas técnicas de simulação há grande abrangência espacial e temporal dos ingredientes microestruturais e dos complexos fenômenos de interação possíveis entre os diversos defeitos de rede nos materiais. Neste contexto, nos processos de simulação a evolução microestrutural do material é prescrita por termodinâmica, onde são avaliados os efeitos da cinética, levando-se em consideração a grande variedade e complexidade de microestruturas. Assim, são tiradas vantagens a partir da observação do perfil das propriedades do material num estado microestrutural, de não-equilíbrio, onde, os defeitos na rede microestrutural, responsáveis por propriedades específicas (na escala macro), são relacionados quantitativamente com o comportamento tecnológico do material (RAABE, 1998).

Nos processos de conformação por estampagem podem ser avaliadas deformações compreendidas entre os estados de tração uniaxial e estiramento biaxial. Estas deformações, que o material suporta, podem ser inseridas em diagramas contendo curvas que apresentam fácil manipulação e entendimento conhecidos como Curva Limite de Conformação (CLC). A representação da CLC é 
indica a fronteira entre deformações permissíveis (suportáveis pelo material) e deformações não suportáveis pelo material, às quais o mesmo está sujeito durante a estampagem. As combinações contidas na área abaixo da curva CLC no gráfico indicam as deformações que a chapa pode suportar, por outro lado, deformações acima da CLC o material não suportará. Quanto maior a área abaixo da curva, maiores são as possibilidades de sucesso ao estampar uma peça. A representação do Diagrama Limite de Conformação mostra o tipo de deformações sofridas pelo material e sua capacidade de deformação (KOHARA 1993; PLAUT 2003; SEMIATIN, 2006). A Figura 4.41a ilustra esquematicamente esta representação e a Figura 4.41b apresenta a Curva Limite de Conformação de uma chapa da liga de alumínio AA3003.

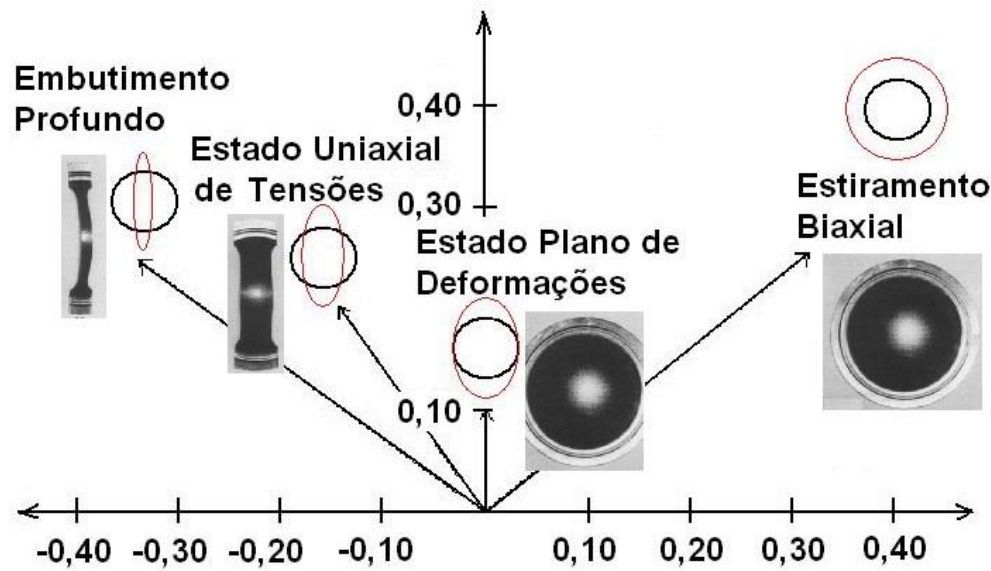

(a) Maior deformação verdadeira $\varepsilon_{1}$

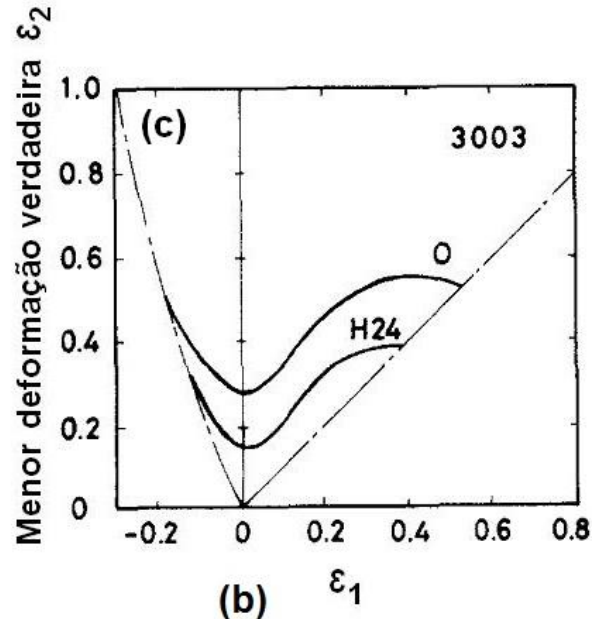

(b)

Figura 4.41 - Desenho esquemático das deformações no embutimento profundo e no estiramento no diagrama limite de conformação (a) e Curva Limite de Conformação de uma chapa da liga de alumínio AA3003 não tratável termicamente (b) (KOHARA 1993).

Na Figura 4.41b pode ser observado que para o mesmo material, a CLC da chapa metálica amolecida $(\mathrm{O})$ se encontra em posições superiores à curva da chapa endurecida (H24). Isto indica que a chapa metálica amolecida apresenta maiores possibilidades de sucesso ao estampar uma peça, nesse caso (KOHARA 1993). Vale lembrar que os parâmetros usados para a análise da estampagem apresentam vantagens, pois os materiais TRC geralmente apresentam mais baixo alongamento uniforme e biaxial do que os materiais obtidos pelo processo DC (ROBERT, 2012). 
Vale ressaltar que processos de conformação e estampagem a quente estão sendo desenvolvidos atualmente na produção de componentes trabalhados, onde aspectos relacionados com as propriedades térmicas, mecânicas, microestruturais e tecnológicas dos metais, estão envolvidos nesses processos. A estampagem a quente é um processo de conformação termo-mecânica com a pretensão de transformação de fase (KARBASIAN, 2010).

A curva de recristalização foi obtida e os fenômenos microestruturais envolvidos durante a recuperação e a recristalização foram estudados. Os valores de temperatura de inicio da recristalização e tempos e temperaturas para a homogeneização das duas amostras (de chapas TRC e $D C$ ) foram obtidos. Não é viável considerá-los de forma rigorosa na indústria, já que, obviamente, as dimensões das amostras são completamente diferentes das dimensões das chapas bobinadas. 


\section{CONCLUSÕES}

Para facilitar a compreensão do leitor, as conclusões foram subdivididas em duas partes: uma relativa às chapas no estado como recebido e a outra parte relativa às chapas nas condições laminada a frio e recozida.

\subsection{Microestrutura e textura cristalográfica das chapas no estado como recebido}

A composição química nas chapas obtidas por lingotamento contínuo $T R C \mathrm{e}$ semicontínuo $D C$ apresentou uma variação pouco significativa ao longo da espessura. A superfície da chapa produzida pelo processo TRC apresentou grãos bem alongados com precipitados mais finos que no centro. Na região central desta chapa foram observadas colônias lamelares de precipitados em grãos de solidificação dendrítica. A chapa produzida pelo processo $D C$ apresentou grãos maiores com ausência de morfologia dendrítica e precipitados alongados e orientados na direção de laminação. A condutividade elétrica nas amostras tratadas a $550^{\circ} \mathrm{C}$ durante duas horas é menor que nas demais, devido à dissolução do Si na matriz de Al. Nas amostras tratadas a $400^{\circ} \mathrm{C}$, em diferentes tempos, a condutividade elétrica é maior que a das amostras no estado como recebido, possivelmente, devido à precipitação de parte do Si. A dureza maior da chapa produzida pelo processo $T R C$ do que da chapa produzida pelo processo $D C$, no estado como recebido, ocorre devido ao endurecimento por deformação durante o processo de produção TRC. As amostras tratadas termicamente da chapa produzida pelo processo TRC, em diferentes temperaturas, apresentaram uma dureza menor que a dureza das amostras no estado como recebido, devido à diminuição da densidade de defeitos cristalinos (discordâncias) e ao conseqüente amolecimento durante o recozimento. Nas amostras da chapa produzida pelo processo $D C$ não houve variação significativa na dureza entre as amostras no estado como recebido e recozidas, pois a chapa havia sido recozida na etapa de homogeneização durante 0 processo industrial $D C$. Os resultados de microanálise química indicaram a presença de precipitados de fases ternárias nas duas chapas. As amostras produzidas pelos dois processos apresentaram tamanhos de grão relativamente grandes, 
principalmente na região central das chapas. A liga produzida por $T R C$ apresentou granulação mais fina que a liga produzida por $D C$.

As componentes de textura cubo, cubo rodado e $\{001\}<310>$ com predominância da componente cubo rodado foram vistas na superfície da chapa produzida pelo processo TRC. Na região de $1 / 4$ da espessura da chapa e no seu centro as componentes de textura encontradas foram cubo, Goss, cobre, latão, S, $\{001\}<310>$ e $\{001\}<320>$, bem como as componentes $S$, cobre e latão que definem a fibra $\beta$. A intensidade da fibra $\beta$ é maior no centro do que na região de $1 / 4$ da espessura. A superfície da chapa produzida pelo processo $D C$ apresentou as componentes de textura cubo, cubo rodado e $\{001\}<310>$, com predominância da componente cubo. Em $1 / 4$ da espessura, as componentes do tipo cubo, cubo rodado e cobre predominam, e no centro as componentes cubo, $\{001\}<310>$ e $\{001\}<320>$ aparecem. A variação nas componentes de textura, ao longo da espessura das chapas, depende fortemente das mudanças geométricas produzidas durante a deformação da tira metálica no processo de produção, causando o aparecimento de uma textura de cisalhamento, nas proximidades da superfície, e uma textura de deformação, bem como a fibra $\beta$, na região interna.

\subsection{Recristalização e textura cristalográfica das chapas laminadas e seguidas de recristalização}

As curvas de amolecimento para as duas chapas produzidas por lingotamento contínuo e lingotamento semicontínuo da liga de alumínio AA4006 foram determinadas e comparadas. Foi possível verificar que a recristalização da tira metálica da liga produzida por TRC ocorre em temperaturas mais elevadas do que na liga produzida pelo processo $D C$. As temperaturas para $50 \%$ de recristalização da amostra da chapa produzida pelo processo TRC e da amostra da chapa produzida pelo processo $D C$ se encontram em torno de $290^{\circ} \mathrm{C}$ e $270{ }^{\circ} \mathrm{C}$, respectivamente. $\mathrm{A}$ precipitação (de Si) na amostra da chapa produzida pelo processo TRC laminada a frio com $70 \%$ de redução, acontece principalmente antes da recristalização e na amostra da chapa produzida pelo processo $D C$ há a possibilidade da ocorrência da precipitação antes e durante a recristalização.

Os resultados da textura cristalográfica mostraram a presença da textura de cisalhamento na superfície e a fibra $\beta$ no centro da amostra laminada a frio $(70 \%$ de 
redução) da chapa produzida pelo processo TRC. Na amostra da chapa produzida pelo processo $D C$, nas mesmas condições, houve a ocorrência da componente cubo e da fibra $\beta$ na superfície e no centro. Uma textura com grãos orientados ao acaso foi vista nas duas amostras laminadas (TRC e $D C$ ), seguidas de recristalização, das duas chapas, possivelmente devido à nucleação estimulada por partículas. Foi detectada também a ausência da fibra $\beta$ nessas amostras. 


\section{REFERÊNCIAS BIBLIOGRÁFICAS}

ABAL Fundamentos do Alumínio e suas Aplicações. São Paulo, Associação Brasileira do Alumínio (ABAL), 2004. 81p.

ABAL Guia Técnico do Alumínio: Características Físico-Químicas. São Paulo, Associação Brasileira do Alumínio (ABAL), 2006. 183p.

ALLEN, C. M., O'REILLY, K. A. Q., CANTOR, B., EVANS, P.V. Intermetallic phase selection in 1XXX Al alloys. Progress in Materials Science. v. 43, p. 89-170, 1998.

ALUMATTER, www.alumatter.info. Acesso em 13 jul. 2010.

BARKER, L. J. Revealing the grain structure of common aluminum alloy metallographic specimens. Transactions of ASM, v. 42, p. 347-359, 1950.

BENUM, S.; ENGLER, O.; NES, E. Rolling and annealing texture in twin roll cast commercial purity aluminium. Materials Science Forum. v. 157, p. 913-918, 1994.

BUNGE H. J. Texture analysis in materials science mathematical methods. Butterworths, 1982. 593p.

CAMPOS, F. C.; FARIAS, M. C. M.; PADILHA, A. F. Uma compilação de valores de energia de defeito de empilhamento para diversos metais. Boletim Técnico da Escola Politécnica da USP, Departamento de Engenharia Metalúrgica e de Materiais, ISSN 1413-2176, p. 1-21, 1999.

COBDEN, R. Aluminium: Physical Properties, Characteristics and Alloys. 1994. Disponível em: www.eaa.net/eaa/education/TALAT/lectures/1501.pdf. Acesso em: 13 jul. 2010.

CULLITY, B. D.; STOCK S. R. Elements of X-ray diffraction. $3^{\text {rd }}$ Edition, Prentice Hall, New Jersey, 2001. 664p. 
DAVIS, J. R. Electrolytic polishing. In: METALS HANDBOOK. Structures and phase diagrams: Metallography. $8^{\text {th }}$ ed. Ohio, American Society for Metals, v. 8, p. 26-33. 1973.

DAVIS, J. R. Introduction to aluminum and aluminum alloys. ASM International. Handbook Committee. Materials Park. Ohio, 1993. 784 p.

DOHERTY, R. D Recrystallization and texture. Progress in Materials Science. v. 42, p. 39-58, 1997.

DOHERTY, R. D.; MARTIN, J. W. The effect of a dispersed second phase on the recrystallization of aluminium-copper alloys. Journal of the Institute of Metals. v. 91, p. 332-338, 1963-64.

ENGLER, O. Nucleation and growth during recrystallisation of aluminium alloys investigated by local texture analysis. Materials Science and Technology. v. 12, p. 859-872, 1996.

ENGLER, O. Influence of particle stimulated nucleation on the recrystallization textures in cold deformed Al-alloys. Part II-Modelling of recrystallization textures. Acta Metallurgica. v. 37, p. 1675-1683, 1997.

ENGLER, O.; HUH, M.-Y; TOMÉ, C.N. A Study of through-thickness texture gradients in rolled sheets. Metallurgical and Materials Transactions A. v. 31, p. 2299-2315, 2000.

ENGLER, O.; KIM, H. C.; HUH, M. Y. Formation of $\{111\}$ fibre texture in recrystallised aluminium sheet. Materials Science and Technology. v. 17, p. 75-86, 2001.

ENGLER, O.; HIRSCH, J. Texture control by thermomechanical processing of AA6xxx Al-Mg-Si sheet alloys for automotive applications - a review. Materials Science and Engineering. v. A336, p. 249-262, 2002. 
ENGLER, O.; HIRSCH, J. Polycristal-plasticity simulation of six and eight ears in deep-drawn aluminum cups. Materials Science and Engineering A. v. 452-453, p. 640-651, 2007.

ENGLER, O.; LÜCKE, K. Mechanisms of recrystallization texture formation in aluminium alloys. Scripta Metallurgica et Materialia. v. 27, p. 1527-1532, 1992.

ENGLER, O.; VATNE, H. E.; NES, E. The roles of oriented nucleation and oriented growth on recrystallization textures in commercial purity aluminium. Materials Science and Engineering. v. A205, p. 187-198, 1996.

FALLEIROS, I. G. S. Qualitative evidence of solute redistribution during grain boundary migration. Metallography, v. 5, p. 125-137, 1972.

FERNANDES, R. C. Efeitos dos teores de manganês e de fero na evolução microestrutural de duas ligas do sistema $\mathrm{Al}-\mathrm{Fe}-\mathrm{Mn}-\mathrm{Si}$ obtidas por lingotamento contínuo (Twin roll caster). São Paulo: Escola Politécnica, Universidade de São Paulo, 2006. 184 p. (Tese de Doutorado).

FERNANDES, R. C., PADILHA, A. F. Efeito dos teores de Mn e de Fe na evolução microestrutural de duas ligas do sistema Al-Fe-Mn-Si obtidas por fundição contínua de chapas (Twin Roll Caster). REM - Revista Escola de Minas, v. 61, p. 165-169, 2008.

GALEGO, E. Desenvolvimento de programa computacional para tratamento de dados de textura obtidos pela técnica de difração de raios X. 2004. 117p. Instituto de Pesquisas Energéticas e Nucleares, São Paulo, 2004. (Dissertação de Mestrado)

GHOSH, G. Aluminium - Iron - Silicon. In: PETZOW, G., EFFENBERG, G. (ed.). v. 5: A Comprehensive Compendium of Evaluated Constitutional Data and Phase Diagrams. 1 ed. Weinheim (Federal Republic of Germany): VCH, cap. 1, 1992. 695 p. 
GOULART, P. R.; SPINELLI, J. E.; BERTELLI, F.; OSÓRIO, W. R. R., GARCIA, A. Cellular Microstructure and Mechanical Properties of a Directionally Solidified Al1.0wt\%Fe Alloy. Materials Science Forum. v. 636-637, p. 564-570, 2010.

GRAS, Ch; MEREDITH, M.; HUNT, J. D. Microstructure and texture evolution after twin roll casting and subsequent cold rolling of Al-Mg-Mn aluminium alloys. Journal of Materials Processing Technology. v. 169, p. 156-163, 2005.

GOLDSTEIN, J. I.; ROMIG Jr., A. D.; NEWBURY D. E.; LYMAN, C. E.; ECHLIN, P.; FIORI, C.; JOY, D. C.; LIFSHIN, E. Scanning Electron Microscopy and X-Ray Microanalysis. $2^{\text {nd }}$ Edition. Plenum Press -New York and London. 1992. 690 p.

GOTTSTEIN, G.; MOLODOV, D. A.; CZUBAYKO, U.; SHVINDLERMAN, L. S. Highangle grain boundary migration in aluminium bicrystals. Journal De Physique IV. v. 5, p. c3-89 - c3-106, 1995.

HANSEN, N.; JUUL JENSEN, D. Deformed metals - structure, recrystallization and strength. Materials Science and Technology. v. 27, p. 1229-1240, 2011.

HOFFMANN, J. C.; CORTES, M. Cooking utensil made from aluminum alloy strips produced by continuous thin gauge twin roll casting. UNITED STATES. no US 2003/0196733 A1, oct, 23, 2003. Patent Application Publication: United States, 2003.

HOSFORD, W. F. The Anisotropy of Aluminum and Aluminum Alloys. Journal of the Minerals, Metals and Materials Society. v. 58, p. 70-74, 2006.

HUMPHREYS, F. J. The nucleation of recrystallization at second phase particles in deformed aluminium. Acta Metallurgica. v. 25, p. 1323-1344, 1977.

INUOE, H.; TAKASUGI, T. Analysis of average orientation distribution in sheet materials with through-thickness texture gradient. Zeitschrift Fur Metallkunde. v. 92, p. 82-88, 2001. 
JACOBS, M. H. Introduction to Mechanical Properties, Solidification and Casting, Joining and Corrosion of Aluminium and its Alloys. 1999. Disponível em: www.eaa.net/eaa/education/TALAT/lectures/1205.pdf. Acesso em: 13 jul. 2010.

JACOBS, M. H. Phase Diagrams. 1999. Disponível em: www.eaa.net/eaa/education/TALAT/lectures/1205.pdf. Acesso em: 13 jul. 2010.

KAMIJO, T.; KATAOKA, S.; INAGAKI, H. Nucleation and growth of cube-oriented recrystallized grains in an aluminum single crystal of an s-orientation. Acta Metallurgica et Materialia. v. 41, p. 1713-1720, 1993.

KAMMER, C. Continuous casting of aluminium. 1999. Disponível em: www.eaa.net/eaa/education/TALAT/lectures/3210.pdf. Acesso em: 13 jul. 2010.

KASSNER, M. E. A case for taylor hardening during primary and steady-state creep in aluminium and type 304 stainless steel. Journal of Materials Science. v. 25, p. 1997-2003, 1990.

KASSNER, M. E.; POLLARD, J.; EVANGELISTA, E.; CERRI, E. Restoration mechanisms in large-strain deformation of high purity aluminum at ambient temperature and the determination of the existence of "steady-state". Acta Metallurgica et Materialia. v. 42, p. 3223-3230, 1994.

KARBASIAN, H.; TEKKAYA, A. E. A review on hot stamping. Journal of Materials Processing Technology. v. 210. p. 2103-2118, 2010.

KLUG, H. P.; ALEXANDER, L. E. X-Ray diffraction procedures, $2^{\text {nd }}$ Edition, Wiley, New York, 1974. 966p.

KOHARA, S. Forming-limit curves of aluminum and aluminum alloy sheets and effects of strain path on the curves. Journal of Materials Processing Technology. v. 38, p.723-735, 1993. 
KÖSTER, U. Recrystallization involving a second phase. Metal Science Journal. v. 8. p. 151-160, 1974.

LIU, W. C.; MORRIS, J. G. Kinetics of the formation of the $\beta$ fiber rolling texture in continuous cast AA 5xxx series aluminum alloys. Scripta Materialia. v. 47, p. 743748, 2002.

LIU, W. C.; ZHAI, T.; MORRIS, J. G. Comparison of recrystallization textures in coldrolled DC and CC AA 5182 aluminum alloys 2003. Materials Science and Engineering A. v. 358, p. 84-93, 2003.

LIU, W. C.; ZHAI, T.; MORRIS, J. G. Texture evolution of continuous cast and direct chill cast AA 3003 aluminum alloys during cold rolling 2004. Scripta Materialia. v. 51, p. 83-88, 2004.

LIMA, L. M. F. G.; Estudo da evolução da textura, da microtextura e da mesotextura de recristalização, após baixos graus de deformação a frio, em dois aços ferríticos com baixo teor de carbono. São Paulo: IPEN-CNEN. Instituto de Pesquisas Energéticas e Nucleares, 2005. 114 p. (Tese de Doutorado).

LIMA, N. B. Influência da textura em medidas de tensão residual. São Paulo: IPENCNEN. Instituto de Pesquisas Energéticas e Nucleares, 1991. 105 p. (Tese de Doutorado).

LÖW M. Determinação do estágio inicial da recristalização em ligas de alumínio por difração de raios-X. São Paulo: IPEN-CNEN. Instituto de Pesquisas Energéticas e Nucleares. 2000. 113 p. (Dissertação de Mestrado).

MACHADO, R. C. Apontamentos da história do alumínio no Brasil. Edição da Fundação Gorceix. 1985. 610p.

MACKENZIE, J. K.; THOMSON, M. J. Second paper on statistics associated with the random disorientation of cubes. Biometrika. v. 45, p. 229-240, 1958. 
MARTINS, J. P. Evolução da microestrutura e da textura durante o processamento de chapas da liga Al-Mn-Fe-Si (3003) produzidas por lingotamento contínuo: um estudo comparativo com o processo semi-contínuo. São Paulo: Escola Politécnica, Universidade de São Paulo, 2005. 171 p. (Tese de Doutorado).

MARTINS, J. P.; CARVALHO, A. L. M.; PADILHA, A. F. Microstructure and texture assessment of $\mathrm{Al}-\mathrm{Mn}-\mathrm{Fe}-\mathrm{Si}$ (3003) aluminum alloy produced by continuous and semicontinuous casting processes. Journal of Materials Science, v. 44, p. $2966-$ 2976, 2009.

MARTINS, J. P.; PADILHA, A. F. Caracterização da liga comercial de alumínio 3003 produzida por fundição contínua de chapas (twin roll caster) - microestrutura. REM Revista Escola de Minas, v. 59, p. 427-431, 2006.

MINATEL, R. Um estudo comparativo sobre a recristalização de chapas de alumínio AA1200 e AA3003 obtidas por lingotamento contínuo (twin roll caster) e por fundição de placas (direct chill). São Paulo: Escola Politécnica, Universidade de São Paulo, 2009. 66 p. (Dissertação de mestrado).

MONDOLFO, L.F. Aluminum alloys: structure and properties. London - Boston: Butterworths, 1976. $971 \mathrm{p}$.

OLIVEIRA, J. C. P. T. Evolução da microestrutura e da textura durante a laminação a frio e a recristalização de alumínio com diferentes níveis de pureza. São Paulo: Escola Politécnica, Universidade de São Paulo, 2009. 261 p. (Tese de Doutorado).

OLIVEIRA, J. C. P. T.; PADILHA, A. F. Caracterização microestrutural dos alumínios comerciais AA1100, AA1050 e AA1070 e do alumínio superpuro AA1199. Revista Escola de Minas, v. 62, p. 373-378, 2009.

OTOMAR, H. P. Estudo comparativo da estampabilidade da liga de alumínio AA1050 partindo de placas obtidas por vazamento direto e bobinas obtidas por vazamento contínuo. São Paulo: Escola Politécnica, Universidade de São Paulo, 2010. 153 p. (Dissertação de Mestrado). 
PADILHA, A. F. Utilização da técnica de difração de elétrons retroespalhados na caracterização microestrutural dos materiais. Boletim Técnico da Escola Politécnica da USP, Departamento de Engenharia Metalúrgica e de Materiais, ISSN 1413-2176, p. 1-16, 1999.

PADILHA, A. F.; PLAUT, R. L. Work Hardening, Recovery, Recrystallization, and Grain Growth. In: TOTTEN, G. E. and MACKENZIE, D. S. (ed.). Handbook of Aluminum. v. 2: Alloy Production and Materials Manufacturing. New York: Marcel Dekker, 724 p. cap. 6, p. 193 - 220. 2003.

PADILHA, A. F.; SICILIANO Jr., F. Encruamento, recristalização, crescimento de grão e textura. São Paulo: ABM, 3ª edição. 2005. 232p.

PLAUT, R. L. Estampabilidade de chapas: ensaios e aplicações. In: Textura e Relações de Orientação: deformação plástica, recristalização e crescimento de grão. TSCHIPTSCHIN et al, 2ª Ed. São Paulo. 2003. p. 265-308.

PORTER, J. R.; HUMPHREYS, F. J. Nucleation of recrystallization At second-phase particles in deformed copper alloys. Metal Science. v. 13, p. 83-88, 1979.

PERES, M. D.; SIQUEIRA, C. A.; GARCIA, A. Macrostructural and microstructural development in Al-Si alloys directionally solidified under unsteady-state conditions. Journal of Alloys and Compounds, v. 381, p. 168-181, 2004.

PIMENTA, F. C.; ARRUDA, A. C. F.; PADILHA, A. F. Resistance to recrystallization in Al-1\% Mn alloys. Zeitschrift für Metallkunde, v. 77, p. 522-528, 1986.

PINTO, A. L.; LOPES, A. M. A utilização da técnica de EBSD em estudos de microtextura e mesotextura. In: Textura e Relações de Orientação: deformação plástica, recristalização e crescimento de grão. TSCHIPTSCHIN et al, São Paulo. 2001. p. 297-311. 
PLAUT, R. L. Estampabilidade de chapas: ensaios e aplicações. In: Textura e Relações de Orientação. TSCHIPTSCHIN et al, 2ª Ed. São Paulo. 2003. p. 265308.

RAABE, D. The Simulation of Materials Microstructures and Properties. In: Computational Materials Science, New York, Wiley-VCH, 1998, 379 p.

RAABE, D. Investigation of the iterative series expansion method by means of standard functions. Materials Letters. v. 22, p. 313-318, 1995.

RANDLE, V.; ENGLER, O. Introduction to texture analysis. Macrotexture, microtexture and orientation mapping. Singapore: Gordon and Breach Science Publishers, 2000. 388p.

RIOS, P. R. A theory for grain-boundary pinning by particles. Acta Metallurgica, v. 35, p. $2805-2814,1987$.

RIOS, R. R.; SICILIANO Jr., F.; SANDIM, H. R. Z.; PLAUT, R. L.; PADILHA, A. F. Nucleation and growth during recrystallization. Materials Research. v. 8, p. 225-238, 2005.

ROBERT, E. SANDERS, Jr. Continuous Casting for Aluminum Sheet: a Product Perspective. TMS, 2012.

SEMIATIN, S. L. Metalworking: Sheet Forming, ASM Handbook. USA. v. 14B, 2006, $924 \mathrm{p}$.

SLÁMOVÁ, M.; OČENÁŠEK, V.; VOORT, G. V. Polarized light microscopy: utilization in the investigation of the recrystallization of aluminum alloys. Materials Characterization. v. 52, n. 3, p. 165-177, 2004.

SOUZA, F. M.; PLAUT, R. L.; LIMA, N. B.; FERNANDES, R. C.; PADILHA, A. F. Microestrutura e textura cristalográfica de chapas da liga AA4006 produzidas por lingotamento contínuo e semicontínuo. In: 12º Seminário de Metais Não Ferrosos - 
Fundamentos - Metalurgia Física, 2011. São Paulo. Anais - ISSN 1984-9885. p. 5767.

SOUZA, F. M.; FERNANDES, R. C.; LIMA, N. B.; PLAUT, R. L.; PADILHA, A. F. Um estudo comparativo entre chapas produzidas pelos processos de lingotamento contínuo e de lingotamento semicontínuo da liga AA4006: microestrutura e textura cristalográfica. REM - Revista Escola de Minas, v. XX, p. XXX-XXX, 2011. (Artigo aceito para publicação).

SOUZA, F. M.; PLAUT, R. L.; LIMA, N. B.; FERNANDES, R. C.; PADILHA, A. F. Recristalização e textura cristalográfica de chapas produzidas por lingotamento contínuo e semicontínuo da liga de alumínio AA4006. REM - Revista Escola de Minas, v. Xx, p. xxx-xxx, 2011. (Artigo submetido para publicação).

SOUZA, S. A. Ensaios Mecânicos de Materiais Metálicos. Edgard Blucher, 1982. $286 \mathrm{p.}$

SPEAR, R. E., GARDNER, G. Dendritic cell size. Transactions AFS, v. 71, p. 209215, 1963.

STÜWE, H. P.; FAUSTMANN, J. Introduccion a las texturas de los materiales metalicos. Madrid, Ed. Montecorvo, 1969, p. 207-250.

TANGEN, S.; SJØLSTAD, K.; FURU, T.; NES E. Effect of Concurrent Precipitation on Recrystallization and Evolution of the P-Texture Component in a Commercial AlMn Alloy. Metallurgical and Materials Transactions A. v. 41A, p. 2970-2983, 2010.

TAYON, W.; CROOKS, R.; DOMACK, M.; WAGNER, J.; ELMUSTAFA, A. A. EBSD Study of Delamination Fracture in Al-Li Alloy 2090. Experimental Mechanics. v. 50, p. 135-143, 2010.

TEGART, W. J. M. The electrolytic and chemical polishing of metals in research and industry. London, Pergamon Press, 1956. 129 p. 
VIAL, C.; HOSFORD, W. F; CADDELL, R. M. Yeld loci of anisotropic sheet metals. International Journal of Mechanical Sciences. v. 25, p. 899-915, 1983.

WOODWARD, R. The Rolling of Aluminium: the Process and the Product. 1994. Disponível em: www.eaa.net/eaa/education/TALAT/lectures/1301.pdf. Acesso em: 13 jul. 2010.

YEUNG, C. F.; LEE, W. B. The effect of homogenization on the recrystallization behaviour of AA4006 Al-Si alloy. Journal of Materials Processing Technology, v. 82 p. 102-106, 1998. 